Illinois State University

ISU ReD: Research and eData

Theses and Dissertations

$10-22-2020$

\title{
Perceptions Of The Indonesia National Curriculum In Relation To Integrated Stem Education At The High School Level
}

Andinisa Rahmaniar

Illinois State University, andin25.11@gmail.com

Follow this and additional works at: https://ir.library.illinoisstate.edu/etd

Part of the Science and Mathematics Education Commons

\section{Recommended Citation}

Rahmaniar, Andinisa, "Perceptions Of The Indonesia National Curriculum In Relation To Integrated Stem Education At The High School Level" (2020). Theses and Dissertations. 1341.

https://ir.library.illinoisstate.edu/etd/1341

This Thesis is brought to you for free and open access by ISU ReD: Research and eData. It has been accepted for inclusion in Theses and Dissertations by an authorized administrator of ISU ReD: Research and eData. For more information, please contact ISUReD@ilstu.edu. 


\section{PERCEPTIONS OF THE INDONESIA NATIONAL CURRICULUM IN RELATION TO \\ INTEGRATED STEM EDUCATION AT THE HIGH SCHOOL LEVEL}

\section{ANDINISA RAHMANIAR}

\section{Pages}

High school students need 21 st-century skills to be competitive in the global economy. STEM education, coupled with problem-solving, critical thinking, innovation, and written and oral communication skills are essential for high school students. In Indonesia, STEM education is not as common as in the United States; some teachers in Indonesia use STEM as a learning method, but it is not included as a major component in the Indonesian curriculum. This study aimed to analyze (a) how teachers implement STEM-based lessons, including hands-on activities and project-based learning in relation to the Indonesia National Curriculum and (b) teachers' prior knowledge about integrating STEM education into the National Curriculum.

A descriptive methodology was utilized for this study; purposive sampling was implemented. The participants were 123 high school STEM-based teachers in West Java, Indonesia. The primary instrument used in this research was a web-based questionnaire, coupled with in-depth interviews. The researcher found that most participants $(60.16 \%)$ utilize projectbased learning and use hands-on activities in $25 \%$ of their courses. In addition, most participants provide a problem in their lesson design to improve students' problem-solving skills. Findings from this study also indicated that most of the participants utilize authentic assessments, such as portfolios in their classes. Statistical analysis of the research instrument used in this study indicated that high school STEM-based teachers know what STEM is and implement some STEM-based 
instruction as part of the Indonesian National Curriculum, and the research participants mentioned that the Indonesian government has already integrated STEM education into the National curriculum, but the details of implementation were not explicit. There is needed to develop the existing National Curriculum that integrates STEM education.

KEYWORDS: STEM Education; Indonesia National Curriculum; Project-based Learning 


\title{
PERCEPTIONS OF THE INDONESIA NATIONAL CURRICULUM IN RELATION TO INTEGRATED STEM EDUCATION AT THE HIGH SCHOOL LEVEL
}

ANDINISA RAHMANIAR

\author{
A Thesis Submitted in Partial \\ Fulfillment of the Requirements \\ for the Degree of \\ MASTER OF SCIENCE \\ Department of Technology \\ ILLINOIS STATE UNIVERSITY
}


Copyright 2020 Andinisa Rahmaniar 


\title{
PERCEPTIONS OF THE INDONESIA NATIONAL CURRICULUM IN RELATION TO INTEGRATED STEM EDUCATION AT THE HIGH SCHOOL LEVEL
}

\author{
ANDINISA RAHMANIAR
}

COMMITTEE MEMBERS:

Chris Merrill, Chair

Joshua Brown

Klaus Schmidt 


\section{ACKNOWLEDGMENTS}

During this thesis work, I received a lot of support and assistance from the people around me.

I would like to thank my Fulbright Scholarship, which has afforded me opportunities to study at Illinois State University; this scholarship helped me financially during my time in the United States before returning to Indonesia.

I would like to thank my thesis chairperson, Dr. Chris Merrill, for his expertise in STEM education; he helped me from the start to the finish of the thesis. I would also like to thank my other committee members, Dr. Joshua Brown and Dr. Klaus Schmidt for their guidance during my studies at Illinois State University.

I would like to thank my friends, Insoraki Swabra, Hanna Tinambunan, Ria Anggraini, Robby Anggriawan, Linh K Nguyen, Nhi, and Asilah, who have truly been my family while I have lived at Illinois State University; they supported me in all of my endeavors.

I would like to thank my family, father, mother, and sisters, who helped me when I did my research in Indonesia; they always supported me, even though they were far away from me. Thank you for all of the prayers while I have been away.

Last, I would like to thank my boyfriend, who supported me and was always patient with me; he helped me find solutions to problems and comforted me during this thesis.

A. $\mathrm{R}$. 


\section{CONTENTS}

Page

ACKNOWLEDGMENTS

CONTENTS

TABLES

FIGURES

CHAPTER I: INTRODUCTION 1

Overview and Statement of Problem 1

Purpose and Scope of the Study $\quad 3$

Research Questions $\quad 3$

$\begin{array}{ll}\text { Theoretical Framework } & 4\end{array}$

$\begin{array}{ll}\text { Significance of the Study } & 4\end{array}$

$\begin{array}{ll}\text { Definitions } & 4\end{array}$

Organization of the Study $\quad 5$

CHAPTER II: LITERATURE REVIEW

$\begin{array}{ll}\text { Background of STEM Education } & 7\end{array}$

Implementation of STEM Education $\quad 9$

History of National Curriculum in Indonesia 11

Frameworks of National Curriculum in 2013 for High School 12

Implementation of STEM Education in Relations to Applying the National Curriculum in

$\begin{array}{ll}\text { Indonesia } & 15\end{array}$

$\begin{array}{ll}\text { Summary } & 16\end{array}$

$\begin{array}{ll}\text { CHAPTER III: METHODOLOGY } & 18\end{array}$ 
$\begin{array}{ll}\text { Research Design } & 18\end{array}$

Participants and Study Setting $\quad 19$

Demographics of Participants $\quad 19$

$\begin{array}{ll}\text { Research Instruments } & 22\end{array}$

$\begin{array}{ll}\text { Pilot Testing } & 23\end{array}$

$\begin{array}{ll}\text { Study Procedures } & 26\end{array}$

$\begin{array}{ll}\text { Summary } & 27\end{array}$

CHAPTER IV: RESULTS AND DISCUSSION 28

$\begin{array}{ll}\text { Survey Findings } & 28\end{array}$

$\begin{array}{ll}\text { Discussion } & 32\end{array}$

CHAPTER V: SUMMARY, CONCLUSION, IMPLICATIONS, AND RECOMENDATIONS 38

$\begin{array}{ll}\text { Summary } & 38\end{array}$

$\begin{array}{ll}\text { Conclusion } & 38\end{array}$

$\begin{array}{ll}\text { Implications } & 39\end{array}$

$\begin{array}{ll}\text { Recommendations } & 39\end{array}$

REFERENCES

APPENDIX A: QUESTIONNAIRE AND INTERVIEW QUESTIONS 48

APPENDIX B: DATA COLLECTION

APPENDIX C: THE CORE COMPETENCIES IN THE NATIONAL CURRICULUM 99 


\section{TABLES}

Table

Page

1. The Implementation Level of the National Curriculum

2. Teaching Field

3. Teaching Grades

4. Teaching Experience

5. Pearson's $r$ coefficient

6. The Cronbach Alpha

7. Implementation Levels of STEM-based Lessons and Activities in Relation to the National

Curriculum

8. Teachers' Perceptions of Integrating STEM education into the National Curriculum 


\section{FIGURES}

Figure $\quad$ Page

1. Development of Indonesia Curriculum (Ministry of Education, 2012) 11

2. Implementation Levels of STEM-based Lessons and Activities in Relation to the National

$\begin{array}{ll}\text { Curriculum } & 28\end{array}$

3. The Teachers' perception of Integrating STEM education into the National Curriculum 32 


\section{CHAPTER I: INTRODUCTION}

\section{Overview and Statement of Problem}

In the 21 st century, students confront complex problems they need to learn how to solve. Saavedra and Opfer (2012) said that students need the following skills in the 21st century: critical thinking, problem-solving, collaboration, leadership agility and compliance, initiative, entrepreneurship, effective oral and written communication, accessing and analyzing information, and curiosity and imagination; these skills can be taught by implementing science, technology, engineering, and mathematics (STEM) education lessons.

STEM education provides learning that encourages students to learn how to solve problems. STEM education in Indonesia is still not typically being implemented at the high school level. Indonesia has a National Curriculum, which means every school and teacher uses the same curriculum; teachers usually cannot make changes to the National Curriculum. Therefore, STEM education in Indonesia is implemented as a learning model or teaching method in Indonesian high school classrooms.

Brown et al. (2011) described that STEM is an integrated multi-discipline of science, technology, engineering, and mathematics. STEM education has three principles: (a) STEM education should advance student learning, (b) provide a logical and authentic connection between and across the individual STEM disciplines, and (c) serve as a bridge to STEM careers. Wilson (2019), espoused that STEM should develop learning, provide a logical and reliable connection between and across the individual STEM disciplines, and serve as a bridge to STEM careers.

The United States of America does not have a national curriculum, so every school, district, state, etc., can make their own independent curricular decisions. On the other hand, Indonesia has 
a National Curriculum where every state and district applies the same curriculum. The problem in Indonesia is that districts cannot incorporate curriculum unilaterally; they have to consider other states and also the government. Because STEM education is not spelled out as part of the Indonesia National Curriculum, teachers in Indonesia lack the ability to apply formal integrated STEM education in their classrooms. Research conducted by Nugroho et al. (2019), found that teachers in Indonesia were familiar with STEM, but additional opportunities to learn and apply integrated STEM education still needs improving.

Suwarma and Kumano (2019) conducted research in Indonesia that focused on teachers' STEM education perspective. In their study, which utilized KTSP (Kurikulum Tingkat Satuan Pendidikan) and the 2013 National Curriculum, the teachers were asked to read the content of the disciplines that they would teach and analyze the content to see if they believed if it could be integrated with STEM. Outcomes of the study revealed that teachers could readily integrate science and mathematics into the content they analyzed but had more difficulty integrating technology and engineering.

Lidinillah et al. (2019) researched the implementation of STEM education in elementary schools. The researchers discovered that elementary teachers lack self-efficacy in their confidence and proficiency in teaching science and mathematics. The same researchers concluded that there is a need to improve teachers' readiness and school support in designing and implementing STEM education for elementary teachers.

This research was aimed at comprehending teachers' understanding of STEM education and the National Curriculum, as well as teachers' readiness to implement STEM education. 


\section{Purpose and Scope of the Study}

The purposes of the research were to (a) analyze the National Curriculum and the integration of STEM education, (b) analyze teachers' understanding of STEM education and the National Curriculum, and (c) better understand teachers' readiness to implement STEM education. STEM teachers across Indonesia may benefit from the study's findings concerning the readiness to teach integrated STEM education based on the National Curriculum.

The study was limited to the analysis of how STEM-based teachers apply the National Curriculum by developing and implementing hands-on, project-based activities into their curriculum, which will help to analyze teachers' perspective about integrating STEM education into National Curriculum in Indonesia. The research participants in this study were STEM-based teachers at the high school and vocational school levels in West Java, Indonesia.

\section{Research Questions}

The research was focused on analyzing how STEM education is integrated into the National Curriculum in Indonesia. Specifically, the research was guided by the following questions:

1. In what ways do high school STEM-based teachers in Indonesia utilize the National Curriculum in their development to design and implement hands-on, project-based activities into their curriculum?

To what extent do high school STEM-based teachers' prior knowledge about integrated STEM education in Indonesia determine how the National Curriculum is implemented? 


\section{Theoretical Framework}

The theoretical framework used in this research was developed by Brown et al. (2011), Suwarma and Kumano (2019) and Brown et al. (2011) described the teachers' perspective of STEM education. They found that some teachers do not understand STEM education, despite knowing that teachers' perception has a leading role in implementing STEM education. Suwarma and Kumano (2019) researched the perceptions of STEM integration into the curriculum; the experimental study focused on preparation of STEM teachers by utilizing two separate curriculum frameworks. The results indicated that STEM education is more effectively implemented in the National Curriculum rather than the previous curriculum.

\section{Significance of the Study}

This study focuses on analyzing the implementation level of STEM-based lessons and activities concerning the National Curriculum in Indonesia at the high school level, and how teachers perceive integrating STEM education into the National Curriculum. The researcher analyzes teachers' perceptions about the integration of STEM education into the National Curriculum. This research may benefit the Indonesian Government, especially the Ministry of Curriculum and Culture, for purposes of identifying where and how integrated STEM education can be implemented into the National Curriculum. Finally, Indonesian high school teachers may benefit from this study because they will better understand how their peers are currently implementing STEM education into their classrooms.

\section{Definitions}

The following terms were operationalized for this study: 
STEM is an acronym of Science, Technology, Engineering, and Mathematics. STEM education is a curriculum that integrates four separate disciplines, such as science, technology, engineering, and mathematics, as one meta-discipline.

A project-based learning approach is a learning approach based on a project. Teachers give a project to their students during their learning process. At the end of class, students present their solution to the project.

The Discovery learning approach is a learning approach that allows students to find concepts of the content by themselves. Teachers encourage and assist students during the learning process by providing some direction to find and understand the course content.

The National Curriculum or 2013 Curriculum revision is Indonesia's curriculum. Indonesia has one National Curriculum that is applied in every school in every state in Indonesia.

Standard-based lessons (SKL (Standar Kompetensi Lulusan), KI (Kompetensi Inti), KD (Kompetensi Dasar)) is the standards term used in The National Curriculum. It is a general phrase that describes the graduate, learning process, content, and assessment competencies that students need to accomplish.

\section{Organization of the Study}

Chapter I is the introduction of the research and describes the background of the research, statement of the problem, scope and limitation of the research, purpose of the research, and its benefits. Chapter II is a review of the related literature on STEM education focused on the research questions guiding this study, the National Curriculum in Indonesia, and implementation of STEM education at the high school level. In Chapter III, a discussion of the research methodology used 
for this study is presented. The findings of the research study are presented in Chapter IV. Chapter $\mathrm{V}$ presents the conclusions of the study, as well as future directions for potential research. 


\section{CHAPTER II: LITERATURE REVIEW}

The purpose of this chapter is to provide a synthesis of the related STEM education literature to help answer the research questions of this study. Next, the history of the National Curriculum in Indonesia is presented, including the 2013 frameworks of the National Curriculum. Finally, related literature is presented on the implementation of STEM education as it relates to the application in the National Curriculum in Indonesia.

\section{Background of STEM Education}

STEM is an acronym for Science, Technology, Engineering, and Mathematics. STEM is an integrated, multi-discipline of science, technology, engineering, and mathematics (Brown et al, 2011). In the 1980s, the reinforcement of science and mathematics education in the United States was an emphasis of discussion and research (e.g., National Commission on Excellence in Education [NCEE], 1983; National Science Foundation [NSF] and U.S. Department of Education in Breiner et al., 2012). Breiner et al. (2012) explained the development of STEM education in the United States as stemming first from the National Science Foundation as interconnected disciplines.

In 2014, U.S. President Obama's Council on Advisors of Science and Technology, as reported by Kennedy and Odell (2014), recommended five steps or areas of improvement that needed to be made in the areas of STEM education:

(a) improve Federal coordination and leadership on STEM education;

(b) support the state-led movement to ensure that the Nation adopts a common baseline for what students learn in STEM;

(c) cultivate, recruit, and reward STEM teachers that prepare and inspire students; 
(d) create STEM-related experiences that excite and interest students of all backgrounds; and

(e) support states and school districts to transform schools into vibrant STEM learning environments.

Then, the National Research Council completed a follow-up report on successful K-12 STEM education, and it refers to several other indicators related to policy and funding STEM:

(a) creating and implementing a national-level monitoring and reporting system to assess progress toward key improvements;

(b) measuring student knowledge, interest, and participation in STEM disciplines and STEMrelated activities;

(c) tracking financial, human, capital, and material investments in K-12 STEM education at the federal, state and local levels;

(d) providing information about the capabilities of the STEM education workforce, including teachers and principals; and

(e) facilitating strategic planning for federal investments in STEM education and workforce development when used with labor force projections (National Research Council, 2012).

The National Research Council (in Kennedy and Odell, 2014) mentioned three goals in implementing K-12 STEM education that is accepted in the U.S.: (a) improving the training and careers in the STEM areas, (b) developing the STEM capable workforce, and (c) increasing scientific literacy for all students. The main goals of STEM education in the U.S., as reported in the NRC study, is to prepare students for post-secondary study and the 21 st-century workforce.

In 2018, the U.S. government created a strategic plan for developing STEM education. They set three goals in a set of priority objective for American STEM education, such as to build 
strong foundations for STEM literacy, increase diversity, equity, and inclusion in STEM, and prepare the STEM workforce for the future. Then, there are four pathways to achieve those goals, such as develop and enrich strategic partnerships that focus on reinforcing the relationship between the institutions in education, employers, and their communities (Committee Council on STEM education of the National Science and Technology, 2018). In other words, the educational institution works together to build the STEM environment on encouraging students to learn and engage students to get work-based learning practice with a local employer. There is a chance to merge the formal and informal learning curriculum that boosts students' academic and nonacademic performance. The second pathway focuses on engaging students where pathway lines converge to make STEM learning more eloquent and stirring by providing real-world, challenging problems to students, which may increase their creativity and innovation. The third pathway is focused on building computational literacy that utilizes technology as tools. The last pathway is operating with transparency and accountability; the way the government and other stakeholders support the implementation of STEM education (Committee on STEM Education of the National Science and Technology Council, 2018).

\section{Implementation of STEM Education}

Williams (2011) discussed why STEM education has not been implemented and the reasons are because the teachers already teach all subjects in one class, so integrated STEM education is not essential. In other perspectives, STEM education is not successful because teachers do not understand their content and learning process design, and students cannot transfer one subject to other subjects. Therefore, the teacher should believe that interaction between disciplines will improve students' learning. Bell (2016) examined another reason of why STEM 
education is needed today because students have become aware of real-world relations. Besides that, his research showed that teachers' perception of STEM and their understanding of the knowledge relates to the effectiveness of STEM implementation. Therefore, the students will understand better if they are being taught by a teacher who has fully understood STEM. When students learn STEM education, they should understand how STEM is interconnected in the implementation of different STEM disciplines to solve problems (Ejiwale, 2013).

STEM education principles, as described by Wilson (2019), include: (a) STEM education should develop learning, (b) provide a logical and reliable connection between and across the individual STEM disciplines, and (c) serve as a bridge to STEM careers. According to the principles presented by Wilson, STEM education should provide a logical and reliable connection, which means technology can engage creative thinking and real-world problem-solving. Wilson also recommended starting STEM education for elementary grades, engaging parents' perception of STEM education, implementing project-based or problem-based learning, and encouraging students with STEM-focus in and outside of school practical learning occasions; these principles can help teachers to develop the learning process, which improves students' real-world problemsolving skills. English (2016) said that STEM education should encourage students to use multiple disciplines' knowledge and skills. English explained that STEM integration correlates with Common Core State Standards for mathematics and Next Generation Science Standards. In addition, STEM education can be integrated from multidisciplinary to interdisciplinary. English (2016) described STEM development that focuses on inquiry process, problem-solving, critical thinking, creativity, and innovation. Therefore, students are encouraged to create new and productive connections in more than two disciplines. 


\section{History of National Curriculum in Indonesia}

Mukminin et al. (2019) completed a literature review about curriculum reform in Indonesia; they explained that Indonesia's educational system is centralized and bureaucratic since the Dutch introduced it while they had colonial power in Indonesia. In 1998, there was a change in the educational system into decentralized law based on Law No.22/1999. The law was implemented officially in January 2001 so that the state and local governments have power and authorization in education; Indonesia still uses centralization as an educational system. The Indonesia curriculum development is based on the Indonesia National principle called Pancasila and the 1945 Constitution of Indonesia; the initial curriculum was developed 1947 (Ministry of Education, 2012). Based on the figure below, the revision of the curriculum happened eleven times.

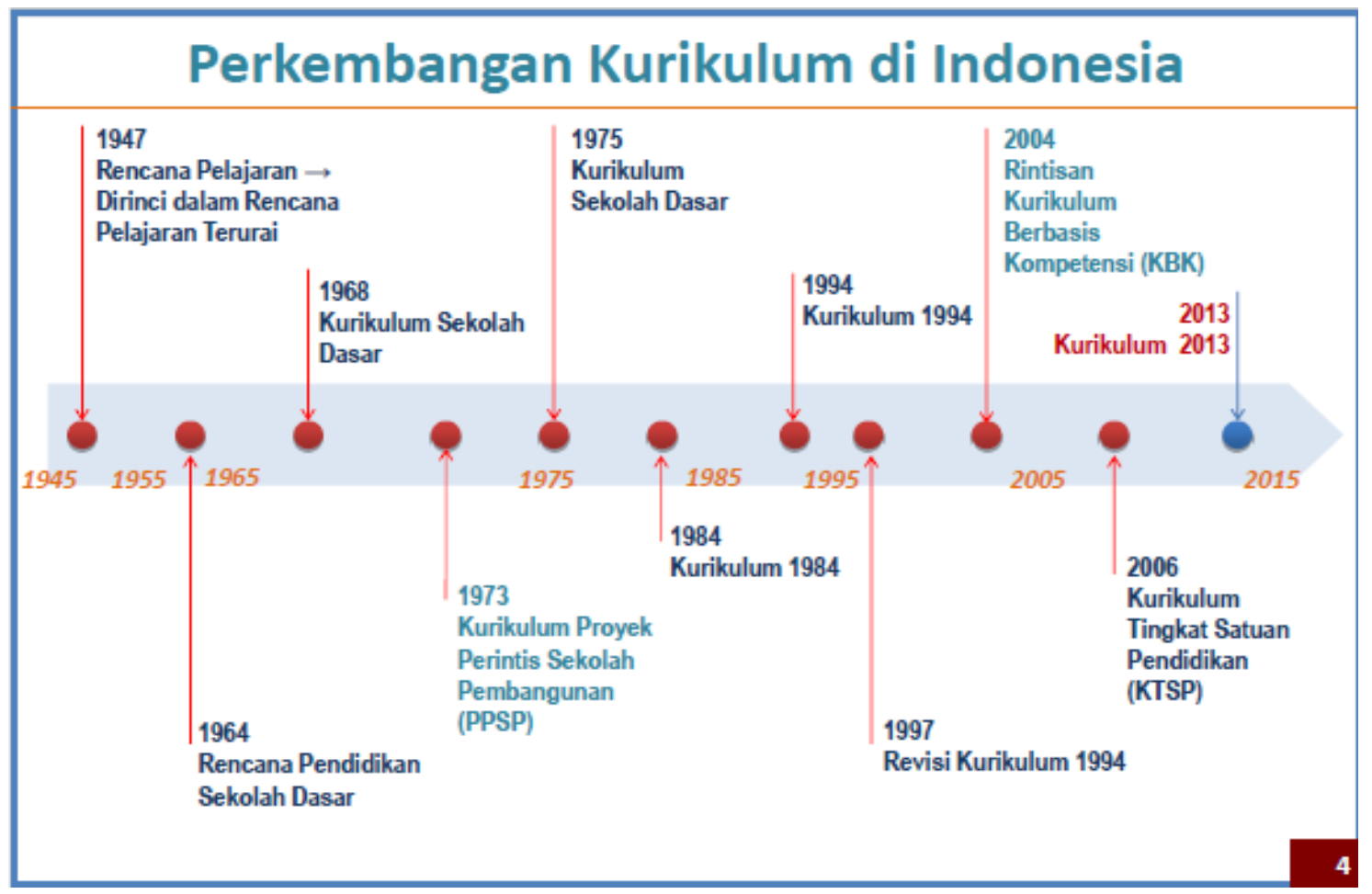

Figure 1. Development of Indonesia Curriculum (Ministry of Education, 2012) 
The current curriculum that Indonesia uses is the 2013 Curriculum. The reasons for the need to develop the 2013 Curriculum was based on Law No. 20,2003 which mentions that building the national education involves developing and realizing the curriculum based on competencies. Graduation qualifications from high school also includes attitude, cognitive, and skill based on the national standard (Ministry of Education and Culture, 2012).

\section{Frameworks of National Curriculum in 2013 for High School}

Indonesia has a curriculum which is called the 2013 Curriculum or National Curriculum. Ratnaningsih (2017) explains that the 2013 Curriculum is the answer to the challenges of advancing technology and rapid globalization. The 2013 Curriculum encourages the learning and innovation skills related to creative thinking, problem-solving, communication, collaboration, creativity, and innovation. In Education Culture Ministry Policy No. 68, 2013, the 2013 Curriculum is intended to develop students' skills to be creative, innovative, skillful, competitive, collaborative, and independent through integrated attitudes, skills, and knowledge.

According to the Ministry of Education and Culture Policy, there are four 2013 Curriculum standards that students need to accomplish: (a) graduate competencies standard, (b) content standard, (c) learning process standard, and (d) assessment standard.

\subsection{Graduate Competencies Standard}

There are three-domains developed in the 2013 Curriculum: attitudes, skills, and cognitive ability for elementary and secondary schools.

1) For attitude, students need to reach five standards, consisting of accepting, realizing, respecting, inspiring, and implementing; 
2) Students need to accomplish seven standards in skills, consisting of observing, asking, trying, processing, presenting, thinking, and creating; and

3) In cognitive ability, students need to accomplish know, understand, implement, analyze, and evaluate.

\subsection{Content Standard}

The standard of content is adjusted with the goals of the national standard. Then, it is developed to create the scope and competence level based on the graduate competency standard. Attitude is split into spiritual and social attitudes. Then, the dimension that represents spiritual attitudes, social attitudes, cognition, and skills are called core competencies. The expansion of core competence is based on the learning goals that are decided by the curriculum development committee. (The Ministry of Education and Culture Policy No. 21, 2016). The content standard for science, mathematics, and technology of the National Curriculum, such as core competencies and learning competencies that students need to accomplish, is in Appendix C. The engineering subject is taught at vocational school.

\subsection{Learning Process Standard}

According to The Ministry of Education and Culture Policy No. 22 (2016), the learning process is realized through interactive, inspirational, fun, challenging, motivating students to participate, giving space to create, creativity, and self-reliance following the talents, interests, and physical and psychological development of students. Prihantoro (2014) described the changes in the standard from the previous curriculum.

1) The standard process focuses on observing, questioning, collecting information, presenting, summing, and creating; 
2) The learning process is not only in the class but also in school and community;

3) Teachers are not the only resources to learn; and

4) Attitudes are taught by example and role models.

Moreover, in the National Curriculum, teachers use a scientific approach to teach students that require 5Ms, such as Mengamati (observing), Menanya (asking questions), Mengumpulkan information (information collecting), and Mengkomunikasikan (communicating). However, there are two more skills, which are Membuat (creating) and Membuat jejaring (networking).

\subsection{Assessment Standard}

The assessment in the 2013 Curriculum is an authentic, competency-based assessment. This assessment evaluates all attitudes, skills, and cognitive competencies based on the process of knowledge and outcome; learning result goals are based on the scores attained on the maximum score. The assessment includes the core, primary, and graduate standard competencies.

In terms of the National Curriculum or 2013 Curriculum revision, there are some changes in the curriculum (The Ministry of Education and Culture Policy No. 35, 2018)

1) The assessment of spiritual and social occur in the religious subject and Public Policy Knowledge Network;

2) The technology and information subject are included in the optional subject;

3) The scientific approach is not the only way to teach students;

4) The remedial lesson is given to students who need it; and

5) The characteristic education is added to create the new generation who has Pancasila and good characteristics to confront the future (The Law of President No.87, 2017). 


\section{Implementation of STEM Education in Relations to Applying the National Curriculum in Indonesia}

In a 2017 study by Ratnaningsih examining the scientific approach taken by English teachers based on the 2013 Curriculum, Ratnaningsih analyzed that teachers apply the scientific approach, such as observing, questioning, experimenting, associating, and communicating.

STEM education is common in the United States, regardless of its meaning or implementation. In Indonesia, however, there is a lack of schools that apply STEM education. Suwarma and Kumano (2019) researched the coherency of STEM education implementation to science on Indonesia's curriculum. Suwarma and Kumano analyzed two curricula: KTSP and 2013 curriculum at elementary and junior high schools. The researchers analyzed teacher training and STEM implementation in the learning process. Bybee (in Suwarma and Kumano, 2019) explains that implementation is based on thinking to coordinate, complement, correlate, combine, or connect the disciplines. The implementation is separated into three steps, such as 2.0 (ST (Sceince and Technology), SM (Science and Mathematics), and EM (Engineering and Mathematics)), 3.0 (STE (Science, Technology, and Mathematics), SEM (Science, Engineering, and Mathematics), TEM (Technology, Engineering, and Mathematics), and MTS (Mathematics, Technology, and Science), and 4.0 (full integration of STEM (Science, Technology, Engineering, and Mathematics)). The research results are that STEM education can be integrated into the 2013 curriculum rather than the KTSP curriculum because the content of science and math on KTSP is overleaped. Based on the research, teachers' perception of STEM education is different from each teacher because of their experience and background. 
Other examples of STEM implementation at the school level can be found in the Milaturrahmah et al. (2017), study that describes STEM's importance as a mathematics learning approach in Indonesia. The researchers analyzed published literature review between 2011 until 2016; they found that STEM education can be implemented to integrate four disciplines (science, technology, engineering, and mathematics) as a learning approach. In Indonesia, STEM education is applied as a learning approach. For example, in a mathematical subject, students think scientifically. Students then use technology like a clinometer to measure a building's height.

Hanif et al. (2019) researched the improvement of students' creativity through STEM-based project learning where in their research, STEM education is applied as a learning process strategy in which students were asked to make a mini projector. The results showed that students who were involved in STEM learning have good creativity in resolution, elaboration, and novelty.

\section{Summary}

STEM education has developed in the United States since 2001. The main goal of STEM education is preparing students for post-secondary study and the 21 st-century workforce. In the United States, every stakeholder in education is encouraged to make its policy based on the federal, national strategy to develop STEM education. Therefore, many schools have implemented STEM education as part of their curriculum. In contrast, Indonesia has a National Curriculum that every school in every state has to use as their curriculum. Thus, teachers do what is mandated in the government curriculum. The current curriculum in Indonesia is the National Curriculum. The curriculum contains standards-based lessons that focus on learning process, content, and assessment competencies that students have to reach after they finish in order to complete their studies. Prior research suggests that students' performance in the 21 st-century depends upon their 
development of their 21 st century skills. In this curriculum, there is no instruction that teachers should implement STEM-based lessons in their learning process, even though there are some parts similar to STEM education principles. Therefore, STEM Education has not been fully implemented in Indonesia. 


\section{CHAPTER III: METHODOLOGY}

The purpose of this chapter is to describe the research methodology used to answer the two research questions of this study, which were (1) In what ways do high school STEM-based teachers in Indonesia utilize the National Curriculum in their development to design and implement handson, project-based activities into their curriculum? and (2) To what extent do high school STEMbased teachers' prior knowledge about integrated STEM education in Indonesia determine how the National Curriculum is implemented?

The purpose of this study was to analyze the National Curriculum and the integration of STEM education, analyze teachers' understanding of STEM education and the National Curriculum, and understanding teachers' readiness to implement STEM education into the National Curriculum.

\section{Research Design}

This research used descriptive analysis methods. Descriptive research uses the naturalistic data that describes a phenomenon and its characteristics (Nassaji, 2015). An empirical technique is a descriptive analysis supporter; it supports the accurate data description, such as means, median, and modes (Loeb, et al., 2017).

Descriptive research does not describe data, it uses data to describe the world for the purpose of identifying and improving our understanding of socially important phenomena (Loeb, et al., 2017). According to Loeb et al. (2017), descriptive analysis starts with a phenomenon that creates questions. In this research, the phenomenon is that teachers in Indonesia rarely implement STEM education because there is no instruction in the National Curriculum for implementation. The researcher created a questionnaire based on the theoretical frameworks of Brown et al. (2011) 
and Sofyan et al. (2016) that studied the National Curriculum's implementation. Additionally, the researcher developed a follow-up questionnaire for additional analyses by interviewing research participants.

The research questions that guided this research study were:

1) In what ways do high school STEM-based teachers in Indonesia utilize the National Curriculum in their development to design and implement hands-on, project-based activities into their curriculum?

2) To what extent do high school STEM-based teachers' prior knowledge about integrated STEM education in Indonesia determine how the National Curriculum is implemented?

\section{Participants and Study Setting}

The sampling technique that was used in this study was purposive sampling. Nardi (2014) explains that purposive or judgmental sampling is selecting a group of participants because they know that they possess the researcher's criteria. In this research, the population was junior and senior high school teachers in Indonesia West Java, Indonesia. The high school is including junior and senior high school ( $7-12$ grades). One hundred twenty-three participants participated in this research study.

\section{Demographics of Participants}

Answers to four questions about participants' demographics were collected: the level of implementation of the National Curriculum, teaching discipline, grade level taught, and years of teaching experience. 
Table 1. The Implementation Level of the National Curriculum

\begin{tabular}{|l|c|c|}
\hline \multicolumn{1}{|c|}{ The Implementation level of the National Curriculum } & Total & Percentages (\%) \\
\hline Fully implemented & 15 & 12.20 \\
\hline $\begin{array}{l}\text { More than half of my curriculum that I teach is based on the National } \\
\text { Curriculum }\end{array}$ & 50 & 40.65 \\
\hline $\begin{array}{l}\text { Less than half of the curriculum I teach is based on the National } \\
\text { Curriculum }\end{array}$ & 52 & 42.88 \\
\hline $\begin{array}{l}\text { I have not implemented the National Curriculum in my courses but rather } \\
\text { developed my own curriculum }\end{array}$ & 6 & 4.88 \\
\hline
\end{tabular}

Table 1. describes how many participants who have implemented the National Curriculum in their STEM-based learning. It shows that $12.2 \%$ of participants have fully implemented the National Curriculum. In contrast, more than $50 \%$ of the participants have implemented less than half of the National Curriculum in their classroom. Even though the National Curriculum has been implemented, few participants have not implemented it yet because they still develop their own curriculum.

Table 2. Teaching Field

\begin{tabular}{|c|c|c|}
\hline The Teaching Field & Total & Percentages (\%) \\
\hline Science & 82 & $66.77 \%$ \\
\hline Technology & 8 & $6.50 \%$ \\
\hline Engineering & 4 & $3.25 \%$ \\
\hline Mathematics & 29 & $23.58 \%$ \\
\hline
\end{tabular}


In Indonesia, the subjects of STEM are taught separately. Science teachers at senior high school are divided into Physics, Biology, and Chemistry. In junior high school, they teach integrated science. Technology teachers teach students about how they operate the computer and how they create new simple technology to apply it in daily life. Engineering subjects are taught in vocational schools. In addition, there are many engineering subjects, such as mechanical engineering, electrical engineering, automotive engineering, etc. Mathematics teachers teach introductory algebra in middle school and pre-calculus in high school. Table 2. shows that the participants are $66.77 \%$ science teachers, $6.50 \%$ technology teachers, $3.25 \%$ engineering teachers, and $23.58 \%$ mathematics teachers.

Table 3. Teaching Grades

\begin{tabular}{|c|c|c|}
\hline Grades & Total & Percentage (\%) \\
\hline Grades 7-9 & 35 & $28.46 \%$ \\
\hline Grades 10-12 & 88 & $71.54 \%$ \\
\hline
\end{tabular}

In this research, the participants teach at junior high schools on seven to nine grades and senior high school on ten to twelve grades. Most of the participants are senior high school teachers (71.54\% of all participants), and the rest of the participants are junior high school teachers. 
Table 4. Teaching Experience

\begin{tabular}{|c|c|c|}
\hline $\begin{array}{c}\text { Teaching } \\
\text { Experience }\end{array}$ & Total & Percentage (\%) \\
\hline$<2$ years & 31 & $25.20 \%$ \\
\hline $2-5$ years & 44 & $35.77 \%$ \\
\hline $6-10$ years & 8 & $6.50 \%$ \\
\hline$>10$ years & 40 & $32.52 \%$ \\
\hline
\end{tabular}

In Table 4., it shows that there is $35.77 \%$ of participants have $2-5$ years' experience in teaching. Besides that, there are $32.52 \%$ of participants has been teaching for more than ten years.

\section{Research Instruments}

This study used a questionnaire coupled with in-depth interviews. Based on Palaiologou et al. (2016), the questionnaire's general format has two sections, demographics and an "issue" section. In this study, the demographic data consisted of school name, personal email, the curriculum implementation, teaching subject, grade level taught, and years of teaching at their particular school. There were two parts to the issue section of the questionnaire. The first part focused on their implementation level of STEM-based lessons and activities as they related to the National Curriculum. The second part of the questionnaire asked about integrating STEM education into the National Curriculum. The issue section data was collected as Likert-scale items, such as Never, $25 \%$ or less, $50 \%$ to $70 \%$ and $100 \%$, and the second part Strongly Disagree, Disagree, Agree, and Strongly Agree. The survey instrument can be found in Appendix A.

At the conclusion of the survey, there is an open-ended question about teachers' perspective of how the government integrates STEM education into the National Curriculum, which was 
adapted from Brown et al. (2011) and Sofyan et al. (2016). The instrument was developed to be delivered through a web-based approach using Qualtrics. The survey was sent to participants by email.

There are ten questions for an in-depth interview to analyze how the research subjects implement STEM education in their classes. The interview was done virtually using phone by the researcher, who was located in the United States, while the participants were in Indonesia. The researcher picked four of fifteen high school STEM-based teachers who participated in the questionnaire and self-identified as fully implementing the National Curriculum in their STEMbased courses.

\section{Pilot Testing}

According to Gorard (2001), all research needs to be pre-tested before it is used in an actual study. The pilot study should be given to participants (population) who are similar (Nardi, 2014). After the pilot study, the researcher analyzed the validity and reliability of the questionnaire. Before the researcher implemented the pilot study, an expert panel examined the questionnaire in this study. Litwin (1995) describes that content validity is the formal review by experts in examining the item's quality in the survey. The expert panel provided input to the researcher before the instrument was given.

In terms of the pilot study, the researcher completed validity and reliability from the pilot study results; 13 subjects participated in the pilot study. After the data was collected, validation and reliability of the survey were calculated. This study used Pearson $r$ for the validation. If the question has the $r$-value $\geq \mathrm{r}$ table, it will be valid (Suyanto, in Aryanti et al., 2019). 
Table 5. Pearson's $r$ coefficient

\begin{tabular}{|c|c|c|c|c|c|c|c|c|c|c|c|c|c|c|c|c|}
\hline & \multicolumn{10}{|c|}{ Questions/Statements } \\
\hline & B.1 & B.2 & B.3 & B.4 & B.5 & B.6 & B.7 & B.8 & B.9 & B.10 & C.1.1 & C.1.2 & C.1.3 & C.1.4 & C.1.5 & C.1.6 \\
\hline Pearson r & 0.19 & 0.19 & 0.29 & 0.78 & 0.15 & 0.45 & -0.01 & 0.36 & 0.73 & 0.59 & 0.24 & 0.76 & -0.05 & 0.41 & -0.21 & 0.47 \\
\hline
\end{tabular}

\begin{tabular}{|c|c|c|c|c|c|}
\hline C.2 & C.3.1 & C.3.2 & C.3.3 & C.3.4 & C.3.5 \\
\hline-0.06 & 0.56 & 0.07 & -0.08 & -0.07 & 0.13 \\
\hline
\end{tabular}

Based on the table of critical value Pearson's $r$, the $r$ table is $0.457(\mathrm{df}=12)$. Hence, 16 questions of 35 were valid. Then, the researcher did an internal consistency to know how the different items measured the same problem (Litwin, 1995). Internal consistency was calculated by using Cronbach Alpha. Ursachi et al. (2015) mentioned that the $\alpha$ value generally accepted is from $0.6-0.7$. Table 2. show the value of $\alpha$ from each question from Minitab. It can be seen that all of the questions have $\alpha$ between $0.6-0.7$. Hence, the questions were found to be reliable.

Table 6. The Cronbach Alpha

\begin{tabular}{|c|c|c|c|c|c|}
\hline Variable & Mean & StDev & Total Corr & Corr & Alpha \\
\hline C1 & 213.077 & 19.090 & 0.1573 & $*$ & 0.7013 \\
\hline C2 & 213.769 & 19.031 & 0.1796 & $*$ & 0.7000 \\
\hline C3 & 213.462 & 19.042 & 0.2565 & $*$ & 0.6997 \\
\hline C4 & 213.538 & 18.707 & 0.7687 & $*$ & 0.6881 \\
\hline C5 & 213.538 & 19.116 & 0.1132 & $*$ & 0.7021 \\
\hline C6 & 213.615 & 19.007 & 0.4293 & $*$ & 0.6982 \\
\hline C7 & 213.538 & 19.186 & -0.0457 & $*$ & 0.7045 \\
\hline C8 & 213.538 & 19.020 & 0.3335 & $*$ & 0.6988 \\
\hline C9 & 213.769 & 18.869 & 0.7356 & $*$ & 0.6934 \\
\hline
\end{tabular}


Table 6, continues

\begin{tabular}{|c|c|c|c|c|c|}
\hline C10 & 213.462 & 18.893 & 0.5707 & $*$ & 0.6944 \\
\hline C11 & 213.538 & 19.073 & 0.2131 & $*$ & 0.7006 \\
\hline C12 & 213.538 & 18.635 & 0.7302 & $*$ & 0.6860 \\
\hline C13 & 214.000 & 19.209 & -0.0678 & $*$ & 0.7067 \\
\hline C14 & 213.231 & 18.974 & 0.3672 & $*$ & 0.6974 \\
\hline C15 & 214.308 & 19.354 & -0.2300 & $*$ & 0.7117 \\
\hline C16 & 214.692 & 18.634 & 0.4584 & $*$ & 0.6881 \\
\hline C17 & 213.769 & 18.485 & 0.7408 & $*$ & 0.6813 \\
\hline C18 & 213.615 & 18.451 & 0.7173 & $*$ & 0.6804 \\
\hline C19 & 213.769 & 18.376 & 0.7845 & $*$ & 0.6777 \\
\hline C20 & 213.308 & 19.015 & 0.2201 & $*$ & 0.6993 \\
\hline C21 & 213.000 & 18.943 & 0.5116 & $*$ & 0.6961 \\
\hline C22 & 213.385 & 18.742 & 0.4758 & $*$ & 0.6905 \\
\hline C23 & 213.846 & 18.774 & 0.6088 & $*$ & 0.6907 \\
\hline C24 & 213.692 & 18.843 & 0.4993 & $*$ & 0.6932 \\
\hline C25 & 213.769 & 19.297 & -0.1954 & $*$ & 0.7090 \\
\hline C26 & 213.692 & 18.571 & 0.4810 & $*$ & 0.6862 \\
\hline C27 & 213.615 & 18.410 & 0.7602 & $*$ & 0.6789 \\
\hline C28 & 213.846 & 18.556 & 0.7023 & $*$ & 0.6837 \\
\hline C29 & 213.385 & 19.055 & 0.1314 & $*$ & 0.7011 \\
\hline C30 & 213.308 & 19.176 & -0.0290 & $*$ & 0.7058 \\
\hline
\end{tabular}


Table 6, continues

\begin{tabular}{|c|c|c|c|c|c|}
\hline C31 & 213.692 & 18.750 & 0.5401 & $*$ & 0.6903 \\
\hline C32 & 213.923 & 19.151 & -0.0007 & $*$ & 0.7050 \\
\hline C33 & 214.231 & 19.249 & -0.1116 & $*$ & 0.7082 \\
\hline C34 & 213.538 & 19.264 & -0.1242 & $*$ & 0.7090 \\
\hline C35 & 214.308 & 19.045 & 0.0662 & $*$ & 0.7037 \\
\hline
\end{tabular}

After testing the questionnaire for validation and reliability, the researcher discussed the results with the committee. Before the questionnaire was distributed to the pilot group, the researcher obtained research approval from IRB to begin the research.

\section{Study Procedures}

The research began by distributing the questionnaire to the participants. The participants were teachers who teach STEM-based content, namely science, technology, engineering, and mathematics in a secondary school in Indonesia. The distribution of the questionnaire was completed electronically. The survey was distributed to 123 participants in West Java, Indonesia. There were 82 science teachers, eight technology teachers, four engineering teachers, and 29 mathematics teachers.

Statistical analysis was completed on the collected data. Then, the survey results were analyzed with the analysis of the National Curriculum and STEM education. The interview results of high school STEM-based teachers supports the analysis of the survey. The questionnaire and list of interview question are located in Appendix A. The data collection can be found in Appendix B. 


\section{Summary}

The researcher utilized descriptive methodology to answer the two research questions for this study. A purposive sampling technique was utilized to identify the participants. One hundred twenty-three participants were identified for this study: 82 science teachers, eight technology teachers, four engineering teachers, and 29 mathematics teachers from West Java, Indonesia. Finally, an open-ended questionnaire and the results of the interviews were utilized to gather additional data to help answer the two research questions of this study. 


\section{CHAPTER IV: RESULTS AND DISCUSSION}

Descriptive analysis helps to determine phenomenon and characteristics. This study analyzed how high school STEM-based teachers in Indonesia are applying the National Curriculum in their development to design and implement hands-on, project-based STEM activities into their curriculum. In addition, the researcher analyzed teachers' perception of integrating STEM education into the National Curriculum. The data was collected by distributing an online survey to STEM-based teachers in West Java, Indonesia.

\section{Survey Findings}

There were 12 questions and statements in the survey and one open-ended question. The first section of the instrument focused on the implementation level of STEM-based lesson activities concerning the National Curriculum. The second section of the instrument collected data on teachers' perception of integrating STEM education into the National Curriculum.

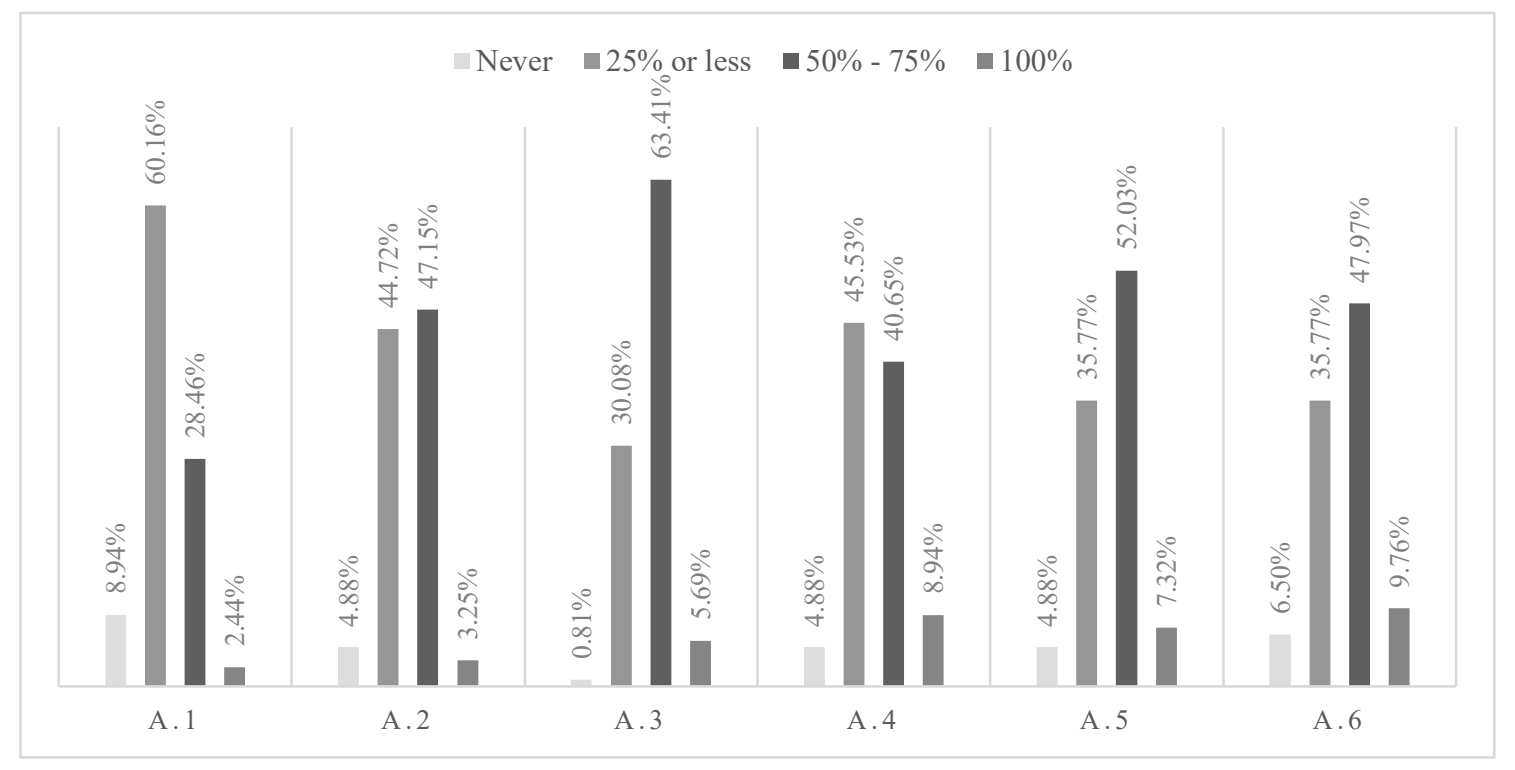

Figure 2. Implementation Levels of STEM-based Lessons and Activities in Relation to the National Curriculum 
Table 7. Implementation Levels of STEM-based Lessons and Activities in Relation to the

National Curriculum

\begin{tabular}{|c|c|c|c|c|c|}
\hline \multirow[b]{2}{*}{ No } & \multirow{2}{*}{ Questions/Statements } & \multicolumn{4}{|c|}{ Responses } \\
\hline & & Never & $25 \%$ or less & $50 \%$ to $75 \%$ & $100 \%$ \\
\hline A.1. & $\begin{array}{l}\text { Based on the implementation of the } \\
\text { National Curriculum, to what extent } \\
\text { do you design STEM-based learning } \\
\text { activities on your courses content } \\
\text { with a project-based learning } \\
\text { approach? }\end{array}$ & $\begin{array}{c}8.94 \% \\
(11)\end{array}$ & $60.16 \%(74)$ & $28.46 \%(35)$ & $\begin{array}{c}2.44 \% \\
\text { (3) }\end{array}$ \\
\hline A.2. & $\begin{array}{l}\text { Based on the implementation of the } \\
\text { National Curriculum, to what extent } \\
\text { do you design STEM-based learning } \\
\text { on your courses content with a } \\
\text { discovery learning approach? }\end{array}$ & $4.88 \%(6)$ & $44.72 \%(55)$ & $47.15 \%(58)$ & $\begin{array}{c}3.25 \% \\
\text { (4) }\end{array}$ \\
\hline A.3. & $\begin{array}{l}\text { Based on the implementation of the } \\
\text { National Curriculum, to what extent } \\
\text { do you give problems to students that } \\
\text { involve a problem-solving process on } \\
\text { your courses content? }\end{array}$ & $0.81 \%(1)$ & $30.08 \%(37)$ & $63.41 \%(78)$ & $\begin{array}{c}5.69 \% \\
(7)\end{array}$ \\
\hline A. 4 . & $\begin{array}{l}\text { Based on the implementation of the } \\
\text { National Curriculum, to what extent } \\
\text { do you design STEM-based activities } \\
\text { that require students to use their } \\
\text { hands (machines, tools, devices, etc.) } \\
\text { on your learning process in the class? }\end{array}$ & $4.88 \%(6)$ & $45.53 \%(56)$ & $40.65 \%(50)$ & $\begin{array}{c}8.94 \% \\
(11)\end{array}$ \\
\hline A.5. & $\begin{array}{l}\text { Based on the implementation of the } \\
\text { National Curriculum, to what extent } \\
\text { do you design STEM-based lessons } \\
\text { and activities that require students to } \\
\text { use knowledge and skill on your } \\
\text { courses content? }\end{array}$ & $4.88 \%(6)$ & $35.77 \%(44)$ & $52.03 \%(64)$ & $\begin{array}{c}7.32 \% \\
(9)\end{array}$ \\
\hline A.6. & $\begin{array}{l}\text { As a STEM teacher, I use student } \\
\text { portfolios to assess STEM-based } \\
\text { knowledge and skill during the } \\
\text { learning process. }\end{array}$ & $6.50 \%(8)$ & $35.77 \%(44)$ & $47.97 \%(59)$ & $\begin{array}{c}9.76 \% \\
(12)\end{array}$ \\
\hline
\end{tabular}


Based on Figure 2. and Table 7., most of the participants (47.15\%) use a discovery learning approach and $60.16 \%$ of participants have implemented project-based learning up to $25 \%$ of their course content. Moreover, there is $63.41 \%$ of participants give problems to students that involve the problem-solving process when they teach their students.

In terms of utilizing hands-on activities in STEM-based learning, $45.53 \%$ of participants use hands-on activities in the class, around $25 \%$ or less of the course content. In contrast, $8.94 \%$ of participants have already fully utilized hands-on activities in STEM-based learning.

"Based on the implementation of the National Curriculum, to what extent do you design

STEM-based lessons and activities that require students to use knowledge and skill on your courses content?” (Question A.5)

On A.5 question, there $52.03 \%$ of participants design STEM-based lessons that require students' skill and knowledge in $50 \%-75 \%$ of their course content. It is more than half of the participants in total. Moreover, one of the assessments that participants used to assess students' performance is the portfolio. Almost half of the participants (47.97\%) use portfolios on 50\% - 75\% of their course content.

Table 8. Teachers' Perceptions of Integrating STEM education into the National Curriculum

\begin{tabular}{|c|l|c|c|c|c|}
\hline \multirow{2}{*}{ No. } & \multicolumn{1}{|c|}{ Statements } & \multicolumn{3}{c|}{ Response } \\
\cline { 3 - 5 } & $\begin{array}{l}\text { Strongly } \\
\text { Disagree }\end{array}$ & Disagree & Agree & $\begin{array}{c}\text { Strongly } \\
\text { Agree }\end{array}$ \\
\hline B.1 & $\begin{array}{l}\text { Based on the National Curriculum, } \\
\text { I believe STEM provides relevance } \\
\text { to the concepts presented in } \\
\text { traditional classes. }\end{array}$ & $2.44 \%(3)$ & $4.07 \%(5)$ & $\begin{array}{c}66.67 \% \\
(82)\end{array}$ & $\begin{array}{c}26.83 \% \\
(33)\end{array}$ \\
\hline B.2 & $\begin{array}{l}\text { Based on the National Curriculum, } \\
\text { I believe it is important to integrate } \\
\text { multiple concepts from STEM in } \\
\text { the same lesson. }\end{array}$ & $0.81 \%(1)$ & $2.44 \%(3)$ & $\begin{array}{c}76.42 \% \\
(94)\end{array}$ & $20.33 \%$ \\
\hline
\end{tabular}


Table 8, continues

\begin{tabular}{|c|c|c|c|c|c|}
\hline B. 3 & $\begin{array}{l}\text { Based on the National Curriculum, } \\
\text { I believe it is important to create } \\
\text { standards-based lessons (SKL, KI, } \\
\text { KD) that focus on integrated STEM } \\
\text { education. }\end{array}$ & $0.81 \%(1)$ & $1.63 \%(2)$ & $\begin{array}{c}69.92 \% \\
(86)\end{array}$ & $\begin{array}{c}27.64 \% \\
(34)\end{array}$ \\
\hline & & Never & $25 \%$ or less & $\begin{array}{c}50 \% \text { to } \\
75 \%\end{array}$ & $100 \%$ \\
\hline B.4 & $\begin{array}{l}\text { As a STEM teacher, I collaborate } \\
\text { with other teachers about best } \\
\text { practices for implementing STEM } \\
\text { education on my courses in the } \\
\text { National Curriculum. }\end{array}$ & $\begin{array}{c}10.57 \% \\
(13)\end{array}$ & $47.15 \%(58)$ & $\begin{array}{c}34.96 \% \\
(43)\end{array}$ & $7.32 \%(9)$ \\
\hline B.5 & $\begin{array}{l}\text { As a STEM teacher, I design } \\
\text { lessons that require students to } \\
\text { reflect on their learning. }\end{array}$ & $2.44 \%(3)$ & $22.76 \%(28)$ & $\begin{array}{c}59.35 \% \\
(73)\end{array}$ & $\begin{array}{c}15.45 \% \\
(19)\end{array}$ \\
\hline B.6 & $\begin{array}{l}\text { As a STEM teacher, I design } \\
\text { lessons that utilize authentic } \\
\text { assessment strategies to measure } \\
\text { student knowledge and skill. }\end{array}$ & $4.07 \%(5)$ & $22.76 \%(28)$ & $\begin{array}{c}56.91 \% \\
(70)\end{array}$ & $\begin{array}{c}16.26 \% \\
(20)\end{array}$ \\
\hline
\end{tabular}

Based on Table 8., statements B.1, B.2, and B.3, $66.76 \%$ of participants noted that STEM education provides relevance concepts to traditional classes. Besides that, most of participants believed that STEM education integrates multiple concepts based on the National Curriculum. They also agreed to integrate STEM education into the curriculum on designing the lesson and create the learning standards. Moreover, most of the participants have collaborated with other teachers to implement STEM education on $25 \%$ of their learning content. Participants provided feedback to their students in $59.35 \%$ of their content courses. In terms of assessment, participants utilized authentic assessment to assess students' performance during the learning process and use authentic assessment in 50\% - 75\% of their course content. 


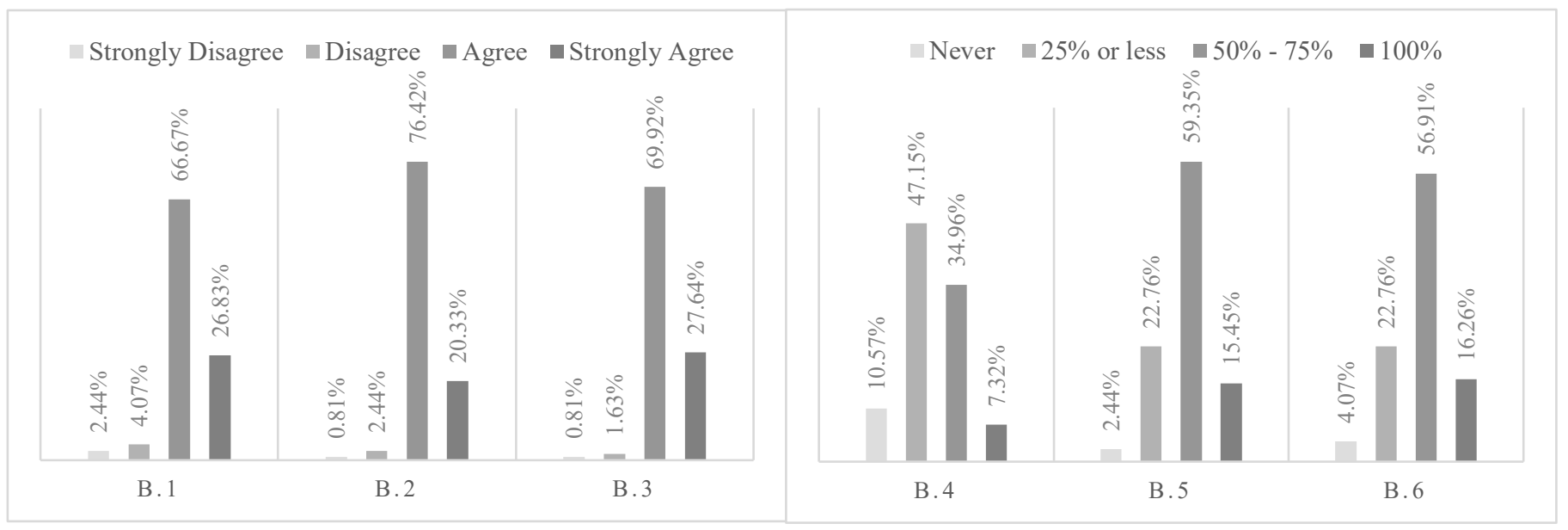

Figure 3. The Teachers' perception of Integrating STEM education into the National Curriculum

Figure 3. shows that all the participants agree and believe that integrating STEM education into the National Curriculum is important. Besides that, most of the participant give feedbacks and use authentic assessment between $50 \%$ and $70 \%$ of their all courses. Then, they do a collaboration with other teachers to implement STEM education on their STEM-based course based on the National Curriculum.

\section{Discussion}

After collecting data from 123 participants who are STEM-based teachers in Indonesia, the data was analyzed to learn how STEM integration into the National Curriculum was accomplished.

The first question that guided this study was: In what ways do high school STEM-based teachers in Indonesia utilize the National Curriculum in their development to design and implement hands-on, project-based activities into their curriculum? Based on the findings of this 
study, most of the participants (60.16\%) use project-based learning to design STEM-based lessons, but they use it around $25 \%$ or less of their overall content course. However, they use more discovery learning in their courses. STEM education can be implemented using any learning method, including project-based learning and discovery-based learning. An additional finding was that more than half of the participants who give educational problems to students involve problemsolving skills. Participants have already provided problems in their learning design, which is one goal of STEM.

According to the analysis of the findings, teachers in Indonesia have applied hands-on activities on $25 \%$ or less of their course content. Moreover, the goal of the development of the National Curriculum is improving students' mindset, such as the improvement of interactive learning, and learning processes based on multimedia. That means students should actively participate in the class, and teachers utilize multimedia to support the learning process (Ministry of Education and Culture Policy No.35, 2018). In fact, participants do not utilize many tools or supporting multimedia to their learning. However, more than half of the participants designed STEM-based lessons that require skill and knowledge. The students' skills and knowledge are assessed by teachers to determine students' performance at the end of the class, which is supported in the National Curriculum.

In terms of assessment, the National Curriculum assesses three aspects of student learning: students' readiness, the process, and the results of learning. Those aspects are concluded to describe the capacity, the style, and learning acquisition of students assessed with authentic assessment (Ministry of Education and Culture Policy No.22, 2016). Based on the findings of this study, most of the participants have already utilized portfolios as their assessment instrument to assess STEM- 
based knowledge and skill during their classes; a portfolio is one of the tools for assessing students' performance in class, that also includes cognitive, attitudes, and skills.

Therefore, secondary STEM-based teachers in Indonesia utilize the National Curriculum in their development to design and implement hands-on, project-based activities into their curriculum, but not for all their course content. They use discovery learning more than projectbased learning, and they do not utilize technology to maximize or support their learning process.

The second research question was to explore to what extent high school STEM-based teachers' prior knowledge about integrated STEM education in Indonesia determines how the National Curriculum is implemented? Based on the research findings, most of the participants agree that STEM education can be integrated into the existing National Curriculum. Participants collaborate with other teachers for $25 \%$ or less of their overall courses during their STEM-based lessons. In the open-ended section of the research instrument, two participants noted that the reason they do not do more collaboration with other teachers was

"teachers are charged with curriculum achievement."

"there is much material that teachers have to accomplish, and the deadline chases teachers".

"it will waste our time more than usual."

In terms of teachers' collaboration, based on the results of in-depth interviews with engineering and technology teachers, they said that they collaborate with other teachers if there is a new technology, but they do not discuss about designing lesson plan together simultaneously. One of the mathematics teachers said that they usually share their teaching experience after they taught in the class and it ruins her lesson plan. Moreover, the collaboration is only with teachers 
in the same field. She said there is no time for teachers in different fields to collaborate; it is because the school does not provide it. In contrast, one of the science teachers explained that she collaborates with other teachers in the science area four times a month. In Indonesia, science lessons are separated into three subjects, such as chemistry, physics, and biology. Thus, science teachers usually collaborate with other science teachers. The collaboration between STEM teachers is not done regularly.

In terms of learning process, the goal of lesson plan development principle on the National Curriculum is providing feedbacks, reinforcement, enrichment, and remedy for students (Ministry of Education and Culture Policy No. 22, 2016). Based on the survey results, it shows that participants have already provided feedback and utilized authentic assessment in their courses. Moreover, from the interview, participants usually give feedback after students finished their assignment or examination. Thus, students can learn from their mistake. One of the engineering teachers said

"For engineering subject, teachers give the feedback right away because if we do not give students feedback directly, it will make students think what they do is right and affect their skill in engineering in the future."

According to the teachers' statement in the open-ended question, some participants did not understand STEM education, especially in urban areas because they have not got the socialization of STEM implementation. However, integrating STEM education into the National Curriculum has been integrated by the government, but there is no explicit instruction for teachers to do STEMbased learning. There is a lot of implied instruction in the Ministry of Education and Culture Policy No. 22, and 23 2016, and No.35 2018. 
Most of the participants said that the implementation of STEM education in Indonesia is not developed yet. Some participants think that STEM education takes more time and wastes time.

"If we utilize STEM in the learning process, it will take more time, and there is a lot of material that has to be covered Besides that, some students do not have a cellphone, so students have difficulties finding information."

Further elicited from the responses was that STEM education is used for certain subjects, such as creating robots, bridges, and plane designs. Some participants think that STEM is creating something at the end of the learning process, not realizing that STEM is not only creating but also how students solve a problem by integrating multiple disciplines. In addition, some schools held STEM education as extracurricular, not as inter-curricular.

All the participants in this research mentioned that integrating STEM education into the National Curriculum needs to be improved and developed. In fact, the development of STEM education implementation did not hold in every state. For example, the government only held the workshops of how to integrate STEM education into the National Curriculum in big states and cities. Therefore, teachers from rural areas could not get the information on the integration of STEM education. However, not all the schools in big cities know about STEM education. Thus, they do not implement STEM education properly.

An additional finding of this study revealed that at least one participant felt that there is a lack of facilities that supports STEM learning.

"STEM is not fit if it wants to be implemented in the area with more citizens in lowerincome families. Besides, there are no laboratories; the students' literacy ability, calculation, and understanding ability are below the standard." 
Moreover, one of the engineering teachers said that school provides learning resources that does not relate to what teachers teach in the classroom. He said that "the principal did not ask to the teachers what kind of books that they need at first and we waste those books." Therefore, teachers find another solution that provides electronical sources that are easier to get and relate more closely to what students learn. 


\section{CHAPTER V: SUMMARY, CONCLUSION, IMPLICATIONS, AND RECOMENDATIONS}

\section{Summary}

Skills that students need in the 21st century and beyond may be obtained from STEMbased learning. This research explains that in Indonesia, implementing STEM education is still not very common; some teachers apply STEM-based learning as a learning method or learning approach and do this from their own initiative, not because of the national curriculum.

STEM education has developed in the United States since 2001. The main goal of STEM education is to prepare students for post-secondary study and the 21 st-century workforce. In the United States, every stakeholder in education is encouraged to make its policy based on the federal national strategy in developing STEM education. Therefore, many schools have implemented STEM education in their curriculum. In contrast, Indonesia has a National Curriculum that every school in every state has to use as their curriculum. The current curriculum in Indonesia is the National Curriculum. In this curriculum, there is no mandate that teachers should implement STEM-based lessons in their learning process, even though there are portions of the curriculum that could be considered STEM education.

\section{Conclusion}

According to the literature review and the findings from this research study, the researcher has determined:

Most of the teachers utilize discovery-based learning in designing STEM-based lessons in their courses. However, $45.53 \%$ of teachers do not use hands-on activities for more than $25 \%$ of their course content. Secondary, STEM-based teachers in Indonesia know what STEM is and believe the National Curriculum integrates STEM education, but its implementation may not be 
sufficient because there is a lack of socialization, facilities, and perceived support from the local government.

While STEM education has been integrated into the National Curriculum in Indonesia in some form, there is no explicit instruction from the Ministry of Education and Culture Policy that requires teachers to integrate STEM education into their curriculum.

\section{Implications}

The results of this study may have an impact on the National Curriculum in Indonesia. The Ministry of Education and Culture may want to consider (a) further developing the National Curriculum to integrate STEM education into the curriculum explicitly, and (b) providing professional development resources to help with teacher readiness to teach integrated STEM education.

\section{Recommendations}

The following recommendations are presented as outcomes of this study:

1. Formal integrated STEM education should occur at the high school level.

2. Although some research about the implementation of STEM education into the Indonesian National Curriculum has occurred, additional research should be conducted on how to best improve students' performance and further develop their 21st-century skills.

3. Additional collaboration between educators, administrators, and the Ministry of Education and Culture should occur regarding ways to improve teachers' awareness of integrating STEM education into the National Curriculum. 
4. The Ministry of Education and Culture may want to investigate ways educational partnerships between schools, communities, and businesses can be developed regarding STEM education at the high school level.

5. The Ministry of Education and Culture examines facilities needed at the high school level in order to implement 21 st Century STEM in equitable ways across Indonesia.

6. Based on this study's findings, there is a need for teacher professional development regarding STEM education implementation at the high school level. The Ministry of Education and Culture may want to consider ways to improve teacher readiness concerning the existing National Curriculum and the implementation of integrated STEM education. 


\section{REFERENCES}

Aryanti, G. A., \& Priastana, I. (2019). Modified Fagerstrom Tolerance Questionnaire (Adolescents) Indonesia Version Validity and Reliabi;ity Study. Indonesian Journal of Health Research, 2(1), 16-22. doi:10.32805/ijhr.2019.2.1.28

Bell, D. I. (2016). The reality of STEM education, design, and technology teachers' perceptions: a phenomenographic study. International Journal of Technology and Design Education, 26(1), 61-79. doi:10.1007/s10798-015-9300-9

Breiner, J. M., Johnson, C. C., Koehler, C. M., \& Harkness, S. S. (2012). What Is STEM? A Discussion About Conceptions of STEM in Education and Partnerships. School Science and Mathematics, 112(1), 3-11. doi:10.1111/j.1949-8594.2011.00109.x

Brown, R., Brown, J., Reardon, K., \& Merrill, C. (2011). Understanding STEM: Current Perception. Technology \& Engineering Teacher, 70(6), 5-9.

Council, C. o. (2018). Charting A Course for Success" America's Strategy for STEM Education. National Science \& Technology Council.

Ejiwale, J. A. (2013). Barriers to Succeccful Implementation of STEM Education. Journal of Education and Learning, 7(2), 63-74. doi:10.11591/edulearn. v7i2.220

English, K. D. (2016). STEM education K-12:perspectives on integration. International Journal of STEM Education, 3(1), 1-8. doi:10.1186/s40594-016-0036-1

Gorard, S. (2001). Quantitative methods in educational research: The role of numbers made easy. New York: Continuum. 
Hanif, S., Wijaya, A. F., \& Nanang, W. (2019). Enhancing Students' Creativity through STEM Project-Based Learning. Journal of Science Learning, 2(2), 50. doi:10.17509/jsl.v2i2.13271

Kennedy, T. J., \& Odell, M. (2014). Engaging Students in STEM Education. Science Education International, 25(3), 246-258.

Lidnillah, D. A., Mulyana, E., Karlimah, K., \& Hanif, G. H. (2019). Integration of STEM learning into the elementary curriculum in Indonesia: An analysis and exploration. Journal of Physics Conference, 1318. doi:10.1088/1742-6596/1318/1/012053

Litwin, M. S. (1999). How to Measure Survey Realibility and Validity. London: SAGE.

Loeb, S., Dynarski, S., McFarland, D., Morris, P., Reardon, S., \& Reber, S. (2017). Descriptive analysis in education: A guide for researchers. Washington, DC: U.S. Department of Education Institute of Education Sciences, National Center for Education Evaluation, and Regional Assistance.

Milaturrahmah, N., Mardiyana, \& Pramudya, I. (2017). Science, technology, engineering, mathematics (STEM) as mathematics learning approach in 21 st century. AIP Conference Proceedings. doi:10.1063/1.4995151

Ministry of Culture and Education of the Republic of Indonesia. (2012). Public Test Materials Curriculum 2013. [Bahan Uji Publik Kurikulum 2013]. Kementerian Pendidikan dan Kebudayaan Republik Indonesia]. 
Ministry of Culture and Education of the Republic of Indonesia. (2013). Regulation of The Minister of Education and Culture Republic of Indonesia No.68: Basic Framework And Curriculum Structure Tsanawiyah Junior High School. [Peraturan Menteri Pendidikan Dan Kebudayaan Republik Indonesia No. 68: Kerangka Dasar Dan Struktur Kurikulum Sekolah Menengah Pertama/Madrasah Tsanawiyah. Kementerian Pendidikan dan Kebudayaan Republik Indonesia].

Ministry of Culture and Education of the Republic of Indonesia. (2016). Regulation of The Minister of Education and Culture Republic of Indonesia No. 21: Basic and Secondary Education Content Standards. [Peraturan Menteri Pendidikan Dan Kebudayaan Republik Indonesia No. 21: Standar Isi Pendidikan Dasar dan Menengah. Kementerian Pendidikan dan Kebudayaan Republik Indonesia].

Ministry of Culture and Education of the Republic of Indonesia. (2016). Regulation of The Minister of Education and Culture Republic of Indonesia No. 22: Basic and Secondary Education Proses Standards. [Peraturan Menteri Pendidikan Dan Kebudayaan Republik Indonesia No. 22: Standar Proses Pendidikan Dasar dan Menengah. Kementerian Pendidikan dan Kebudayaan Republik Indonesia]. 
Ministry of Culture and Education of the Republic of Indonesia. (2018). Regulation of The Minister of Education and Culture Republic of Indonesia No.35: Changes to the regulation of the minister of education and culture Number 58 of 2014 on Curriculum 2013 Tsanawiyah junior high school. [Peraturan Menteri Pendidikan Dan Kebudayaan Republik Indonesia No. 35: Perubahan Atas Peraturan Menteri Pendidikan Dan Kebudayaan Nomor 58 Tahun 2014 Tentang Kurikulum 2013 Sekolah Menengah Pertama/Madrasah Tsanawiyah. Kementerian Pendidikan dan Kebudayaan Republik Indonesia].

Ministry of Culture and Education of the Republic of Indonesia. (2018). Regulation of The Minister of Education and Culture Republic of Indonesia No.36: Changes to the regulation of the minister of education and culture Number 59 of 2014 on Curriculum 2013 Aliyah high school/senior high school. [Peraturan Menteri Pendidikan Dan Kebudayaan Republik Indonesia No. 35: Perubahan Atas Peraturan Menteri Pendidikan Dan Kebudayaan Nomor 59 Tahun 2014 Tentang Kurikulum 2013 Sekolah Menengah Atas/Madrasah Aliyah. Kementerian Pendidikan dan Kebudayaan Republik Indonesia]. 
Ministry of Culture and Education of the Republic of Indonesia. (2018). Regulation of The Minister of Education and Culture Republic of Indonesia No.37: Changes to the regulation of the minister of education and culture Number 24 of 2016 on core competencies (KI) and basic competencies (KD) lessons in the curriculum 2013 level of elementary, junior high school, senior high school. [Peraturan Menteri Pendidikan Dan Kebudayaan Republik Indonesia No. 37: Perubahan Atas Peraturan Menteri Pendidikan Dan Kebudayaan Nomor 24 Tahun 2016 Tentang Kompetensi Inti (KI) Dan Kompetensi Dasar (KD) Pelajaran Pada Kurikulum 2013 Jenjang SD, SMP, SMA. Kementerian Pendidikan dan Kebudayaan Republik Indonesia].

Mukminin, A., Habibi, A., Prasojo, L. D., Idi, A., \& Hamidah, A. (2019). Curriculum Reform in Indonesia: Moving from an Exclusive to Inclusive Curriculum. Center for Educational Policy Studies Jourrnal, 9(2), 53. doi:10.26529/cepsj.543

Nardi, P. M. (2014). Doing Survey Research: A guide to quantitative methods. Boulder: Routledge.

Nassaji, H. (2015). Qualitative and descriptive research: Data type versus data analysis. Language Teaching Research, 19(2), 129-132. doi:10.1177/1362168815572747

Nugroho, O. F., Permanansari, A., \& Firman, H. (2019). The Movement of STEM Education in Indonesia: Science Teachers' Perspective. Jurnal Pendidikan IPA Indonesia, 8(3). doi:10.15294/jpii.v8i3.19252

Palaiologou, I., Needham, D., \& Male, T. (2016). Doing Research in Education: Theory and Practice. Los Angeles: SAGE. 
President of Republic of Indonesia. (2017). The Law of President of Republic of Indonesia No.87: Strengthening of Character Education. [Peraturan Presiden Republik Indonesia No. 87: Penguatan Pendidikan Berkarakter. Presiden Republik Indonesia].

Ratnaningsih, S. (2017). Scientific approach of 2013 curriculum: Teachers' implementation in english Language Teaching. English Review: Journal of English Education, 6(1), 33-40. doi:10.25134/erjee.v6i1.768.

Saavedra, A. R., \& Opfer, V. D. (2012). Learning 21st- Century Skills Requires 21st-Century Teaching. Phi Delta Kappan, 94(2), 8-13. doi:10.1177/003172171209400203

Sofyan, H., Komariah, K., \& Wagiran. (2016). The Implementation of Problem Based Learning in the 2013 Curriculum. International Conference on Innovation in Engineering and Vocational Education, 64-69.

Suwarma, I. R., \& Kumano, Y. (2019). Implementation of STEM education in Indonesia: teachers' perception of STEM integration into curriculum. Journal of Physics: Conference Series . doi:10.1088/1742-6596/1280/5/052052

Suyanto, S. (2017). A reflection on the implementation of a new curriculum in Indonesia: A crucial problem on school readiness. AIP Conference Proceedings. 1868, pp. 1-9. AIP Publishing. doi:10.1063/1..4995218

Ursachi, G., Horodnic, I. A., \& Zait, A. (2015). How reliable are measurement scales? External factors with indirect influence on reliability estimators. Procedia Economics and Finance, 20, 679-686. doi:10.1016?S2212-5671(15)00123-9

Williams, P. J. (2011). STEM Education: Proceed with caution. Design and Technology Education: An International Journal, 16(1). 
Wilson, H. W. (2019). The power of collaboration for change. Technology and Engineering Teacher, 78(6), 1-7. 


\title{
APPENDIX A: QUESTIONNAIRE AND INTERVIEW QUESTIONS
}

\section{Questionnaire}

\section{Perceptions of the Indonesia National Curriculum in Relation to Integrated STEM}

\author{
Education at the High School
}

Persepsi Kurikulum Nasional Indonesia Terkait Dengan Integrasi Pendidikan STEM Di

\section{Sekolah Menengah Atas}

Email

Institution/Sekolah :

\section{Teachers' Background}

Latar Belakang Guru

1. To what extent have you implemented the Indonesian National Curriculum in your STEMbased courses?

Sejauh mana Anda telah menerapkan Kurikulum Nasional Indonesia dalam program berbasis STEM Anda?

a. Fully implemented

Terimplementasi sepenuhunya

b. More than half of my curriculum that I teach is based on the National Curriculum Lebih dari separuh kurikulum saya yang saya ajarkan berdasarkan Kurikulum Nasional

c. Less than half of the curriculum I teach is based on the National Curriculum Kurang dari setengah kurikulum yang saya ajarkan berdasarkan Kurikulum Nasional

d. I have not implemented the National Curriculum in my courses, but rather developed my own curriculum.

Saya belum menerapkan kurikulum nasional dalam pembelajaran, melainkan mengembangkan kurikulum saya sendiri.

2. What is your primary teaching discipline within your school? Apa mata pelajaran yang Anda ajarkan? 

a. Science/ IPA
b. Technology /Teknologi
c. Engineering/Teknik
d. Mathematics/ Matematika

3. What grades do you teach?

Pada tingkatan kelas berapa Anda mengajar?
a. Grades 7-9/ Kelas 7-9
b. Grades 10-12/ Kelas 10-12

4. How long have you been teaching?

Berapa lama Anda mengajar?
a. $<2$ years/tahun
b. $2-5$ years/tahun
c. $6-10$ years/tahun
d. $>10$ years/tahun

A. The first section of this survey instrument (two in total) focuses on your implementation levels of STEM-based lessons and activities in relation to the National Curriculum. Please read each question and select your response.

Bagian pertama dari instrumen survei ini (terdapat dua bagian secara keseluruhan) berfokus pada tingkat pelaksanaan pembelajaran dan kegiatan berbasis STEM dalam kaitannya dengan Kurikulum Nasional. Silakan baca setiap pertanyaan dan pilih Tanggapan Anda.

\begin{tabular}{|c|c|c|c|c|c|}
\hline \multirow[b]{2}{*}{ No } & \multirow[b]{2}{*}{$\begin{array}{l}\text { Questions/Statements } \\
\text { Pertanyaan/Pernyataan }\end{array}$} & \multicolumn{4}{|c|}{$\begin{array}{l}\text { Responses } \\
\text { Jawaban }\end{array}$} \\
\hline & & $\begin{array}{l}\text { Never } \\
\text { Tidak } \\
\text { pernah }\end{array}$ & $\begin{array}{c}25 \% \text { or } \\
\text { less } \\
25 \% \\
\text { atau } \\
\text { kurang }\end{array}$ & $\begin{array}{c}50 \% \text { to } \\
75 \% \\
50 \%- \\
70 \%\end{array}$ & $100 \%$ \\
\hline
\end{tabular}




\begin{tabular}{|l|l|l|l|}
\hline 1. & $\begin{array}{l}\text { Based on the implementation of the National } \\
\text { Curriculum, to what extent do you design } \\
\text { STEM-based learning activities on your courses } \\
\text { content with a project-based learning approach? } \\
\text { Berdasarkan pelaksanaan Kurikulum Nasional, } \\
\text { sejauh mana Anda merancang kegiatan } \\
\text { pembelajaran berbasis STEM pada mata } \\
\text { pelajaran yang Anda ajarkan dengan } \\
\text { pendekatan pembelajaran berbasis proyek? }\end{array}$ \\
\hline $\mathbf{2 .}$ & $\begin{array}{l}\text { Based on the implementation of the National } \\
\text { Curriculum, to what extent do you design } \\
\text { STEM-based learningon your courses content } \\
\text { with a discovery learning approach? } \\
\text { Berdasarkan pelaksanaan Kurikulum Nasional, } \\
\text { sejauh mana Anda mendesain pembelajaran } \\
\text { berbasis STEM pada mata pelajaran yang Anda } \\
\text { ajarkan dengan pendekatan discovery? } \\
\text { Based on the implementation of the National } \\
\text { Curriculum, to what extent do you give } \\
\text { problems to students that involve a problem- } \\
\text { solving process on your courses content? }\end{array}$
\end{tabular} \mid




\begin{tabular}{|l|l|l|l|}
\hline $\begin{array}{l}\text { Berdasarkan pelaksanaan Kurikulum Nasional, } \\
\text { sejauh mana Anda memberikan masalah kepada } \\
\text { siswa yang melibatkan proses pemecahan } \\
\text { masalah pada mata pelajaran yang Anda } \\
\text { ajarkan? }\end{array}$ & $\begin{array}{l}\text { Based on the implementation of the National } \\
\text { Curriculum, to what extent do you design } \\
\text { STEM-based activities that require students to } \\
\text { use their hands (machines, tools, devices, etc.) } \\
\text { on your learning process in the class? } \\
\text { Berdasarkan pelaksanaan Kurikulum Nasional, } \\
\text { sejauh mana Anda merancang kegiatan berbasis } \\
\text { STEM yang mengharuskan siswa untuk } \\
\text { menggunakan tangan mereka (mesin, alat, } \\
\text { perangkat, dll) pada proses pembelajaran di } \\
\text { kelas? }\end{array}$
\end{tabular} \mid




\begin{tabular}{|c|c|}
\hline & $\begin{array}{l}\text { Berdasarkan pelaksanaan Kurikulum Nasional, } \\
\text { sejauh mana Anda mendesain pembelajaran dan } \\
\text { kegiatan berbasis STEM yang mengharuskan } \\
\text { siswa untuk menggunakan pengetahuan dan } \\
\text { keterampilan pada mata pelajaran yang Anda } \\
\text { ajarkan? }\end{array}$ \\
\hline 6. & $\begin{array}{l}\text { As a STEM teacher, I use student portfolios to } \\
\text { assess STEM-based knowledge and skill during } \\
\text { the learning process. } \\
\text { Sebagai guru STEM, saya menggunakan } \\
\text { portofolio siswa untuk menilai pengetahuan dan } \\
\text { keterampilan berbasis STEM selama proses } \\
\text { pembelajaran. }\end{array}$ \\
\hline
\end{tabular}

B. The second section of this survey instrument focuses on integrated STEM education in relation to the National Curriculum. Please read each question and select your response.

Bagian kedua dari instrumen survei ini berfokus pada pendidikan STEM yang terintegrasi dalam kaitannya dengan Kurikulum Nasional. Silakan baca setiap pertanyaan dan pilih Tanggapan Anda. 


\begin{tabular}{|c|c|c|c|c|c|}
\hline \multirow[b]{2}{*}{ No. } & \multirow[b]{2}{*}{$\begin{array}{l}\text { Questions/ Statements } \\
\text { Pertanyaan/Pernyataan }\end{array}$} & \multicolumn{4}{|c|}{$\begin{array}{l}\text { Response } \\
\text { Jawaban }\end{array}$} \\
\hline & & $\begin{array}{c}\text { Strongly } \\
\text { Disagree } \\
\text { Sangat Tidak } \\
\text { Setuju }\end{array}$ & $\begin{array}{c}\text { Disagree } \\
\text { Tidak } \\
\text { Setuju }\end{array}$ & $\begin{array}{l}\text { Agree } \\
\text { Setuju }\end{array}$ & $\begin{array}{c}\text { Strongly } \\
\text { Agree } \\
\text { Sangat } \\
\text { Setuju }\end{array}$ \\
\hline 1. & $\begin{array}{l}\text { Based on the National Curriculum, I } \\
\text { believe STEM provides relevance to } \\
\text { the concepts presented in traditional } \\
\text { classes. } \\
\text { Berdasarkan Kurikulum Nasional, } \\
\text { saya percaya STEM memberikan } \\
\text { keterkaitan antara konsep yang } \\
\text { disajikan dalam kelas tradisional. }\end{array}$ & & & & \\
\hline 2. & $\begin{array}{l}\text { Based on the National Curriculum, I } \\
\text { believe it is important to integrate } \\
\text { multiple concepts from STEM in the } \\
\text { same lesson. } \\
\text { Berdasarkan Kurikulum Nasional, } \\
\text { saya percaya pentingnya } \\
\text { mengintegrasikan beberapa konsep }\end{array}$ & & & & \\
\hline
\end{tabular}




\begin{tabular}{|c|c|c|c|c|c|}
\hline & $\begin{array}{l}\text { dari STEM dalam pembelajaran yang } \\
\text { sama. }\end{array}$ & & & & \\
\hline \multirow[t]{2}{*}{3.} & $\begin{array}{l}\text { Based on the National Curriculum, I } \\
\text { believe it is important to create } \\
\text { standards-based lessons (SKL, KI, } \\
\text { KD) that focus on integrated STEM } \\
\text { education. } \\
\text { Berdasarkan Kurikulum Nasional, } \\
\text { saya percaya pentingnya menciptakan } \\
\text { pelajaran berbasis standar (SKL, KI, } \\
\text { KD) yang berfokus pada pendidikan } \\
\text { STEM terpadu. }\end{array}$ & & & & \\
\hline & & $\begin{array}{c}\text { Never } \\
\text { Tidak pernah }\end{array}$ & $\begin{array}{c}25 \% \text { or } \\
\text { less } \\
25 \% \\
\text { atau } \\
\text { kurang }\end{array}$ & \begin{tabular}{|r|}
$50 \%$ \\
to \\
$75 \%$
\end{tabular} & $100 \%$ \\
\hline 4. & $\begin{array}{l}\text { As a STEM teacher, I collaborate with } \\
\text { other teachers about best practices for } \\
\text { implementing STEM education on my } \\
\text { courses in the National Curriculum. }\end{array}$ & & & & \\
\hline
\end{tabular}




\begin{tabular}{|l|l|l|l|l|}
\hline & $\begin{array}{l}\text { Sebagai guru STEM, saya } \\
\text { berkolaborasi dengan guru lain } \\
\text { tentang praktik terbaik untuk } \\
\text { melaksanakan pendidikan STEM pada } \\
\text { mata pelajaran yang yang ajarkan } \\
\text { dalam Kurikulum Nasional. }\end{array}$ & & & \\
\hline 5. & $\begin{array}{l}\text { As a STEM teacher, I design lessons } \\
\text { that require students to reflect on their } \\
\text { learning. } \\
\text { Sebagai guru STEM, saya merancang } \\
\text { pembelajaran yang mengharuskan } \\
\text { siswa untuk merefleksikan } \\
\text { pembelajaran mereka. }\end{array}$ & & & \\
\hline 6. & $\begin{array}{l}\text { As a STEM teacher, I design lessons } \\
\text { that utilize authentic assessment } \\
\text { strategies to measure student } \\
\text { knowledge and skill. } \\
\text { Sebagai guru STEM, saya merancang } \\
\text { pelajaran yang memanfaatkan strategi } \\
\text { penilaian otentik untuk mengukur } \\
\text { pengetahuan dan keterampilan siswa. }\end{array}$ & & & \\
\hline
\end{tabular}


In the space provided, please describe your perspective, of how the government integrates STEM education into the National curriculum?

Di bagian yang telah disediakan, jelaskan perspektif Anda, bagaimana pemerintah mengintegrasikan pendidikan STEM terhadap Kurikulum Nasional?

\section{Virtual Interview Questions}

Adapted from Brown et.al (2011)

1. What do you think about STEM education? Apa pendapat Anda tentang pendidikan STEM?

2. How does your definition of STEM Education affect the curriculum and instruction in your class?

Bagaimana definisi Anda tentang pendidikan STEM mempengaruhi kurikulum dan pengajaran di kelas Anda?

3. Is STEM Education important? If so, why? Apakah pendidikan STEM penting? Jika demikian, mengapa?

4. How often do you talk with other teachers in the STEM disciplines about what you are doing in your class?

Seberapa sering Anda berdiskusi dengan guru lain mengenai pembelajaran STEM tentang apa yang Anda lakukan di kelas Anda?

5. Do you ever collaborate with other teachers by doing theme-based lessons or co-teaching? Apakah Anda pernah berkolaborasi dengan guru lain dengan melakukan pelajaran berbasis tema atau rekan mengajar?

6. How do you implement and integrate all aspects of the National Curriculum into the lesson plan and teaching? 
Bagaimana Anda mengimplementasikan dan mengintegrasikan semua aspek Kurikulum

Nasional ke dalam rencana pembelajaran dan pengajaran?

7. How do you integrate STEM education into the National Curriculum? Bagaimana Anda mengintegrasikan pendidikan STEM ke dalam Kurikulum Nasional?

8. What kind of assessment that you use to assess students' performance in STEM learning based on the National Curriculum standard?

Apa jenis penilaian yang Anda gunakan untuk menilai kinerja siswa dalam pembelajaran

STEM berdasarkan standar Kurikulum Nasional?

9. How do you give feedback on students' performance in the class?

Bagaimana Anda memberikan umpan balik terhadap kinerja siswa di kelas?

10. Could you explain the resources that influence STEM learning in your class?

Bisakah Anda menjelaskan sumber daya yang mempengaruhi pembelajaran STEM di kelas Anda 
APPENDIX B: DATA COLLECTION

\begin{tabular}{|c|c|c|c|c|c|c|c|c|c|c|c|c|c|c|c|c|c|}
\hline School Name & D. 1 & D.2 & D. 3 & D. 4 & A. 1 & A. 2 & A. 3 & A.4 & A. 5 & A. 6 & B. 1 & B. 2 & B.3 & B.4 & B. 5 & B.6 & $\begin{array}{l}\text { Open-ended question's } \\
\text { answer }\end{array}$ \\
\hline $\begin{array}{c}\text { SMA/SMK Al } \\
\text { Muhajirin } 3 \text { Purwakarta }\end{array}$ & 2 & 1 & 2 & 2 & 1 & 3 & 3 & 2 & 3 & 3 & 4 & 3 & 3 & 2 & 4 & 3 & $\begin{array}{l}\text { Saat ini pemerintah } \\
\text { memerintahkan agar guru di } \\
\text { sekolah menyesuaikan } \\
\text { kurikulum nasional dengan } \\
\text { kebutuhan setiap sekolah } \\
\text { karena setiap sekolah } \\
\text { memiliki siswa yang } \\
\text { memiliki kebutuhan berbeda } \\
\text { sehingga pemerintah tidak } \\
\text { secara langsung } \\
\text { memerintahkan sekolah untuk } \\
\text { mengintegrasikan pendidikan } \\
\text { STEM. Namun, pendidikan } \\
\text { STEM sangat dianjurkan } \\
\text { untuk dilaksanakan di era } \\
\text { digitalisasi 4.0 ini karena } \\
\text { STEM mengintegrasikan } 4 \\
\text { ilmu disipliner seperti IPA, } \\
\text { teknologi, teknik, dan } \\
\text { matematika. Untuk melatih } \\
\text { kemampuan berpikir tingkat } \\
\text { tinggi siswa, diperlukan } \\
\text { proses pembelajaran yang } \\
\text { mendukung terciptanya } \\
\text { output tersebut. Dengan } \\
\text { mengintegrasikan STEM, }\end{array}$ \\
\hline
\end{tabular}




\begin{tabular}{|c|c|c|c|c|c|c|c|c|c|c|c|c|c|c|c|c|c|}
\hline & & & & & & & & & & & & & & & & & $\begin{array}{l}\text { siswa dituntut untuk lebih } \\
\text { kritis dalam berpikir dan } \\
\text { memecahkan suatu masalah. } \\
\text { Selain itu, siswa juga dituntut } \\
\text { untuk lebih aktif dan aplikatif } \\
\text { dalam pembelajaran. Sejauh } \\
\text { ini baru sekolah-sekolah } \\
\text { tertentu yang sudah } \\
\text { melaksanakan STEM. } \\
\text { Sebagian diantaranya } \\
\text { terkendala di masalah } \\
\text { minimnya ilmu para guru } \\
\text { untuk mengintegrasikan } \\
\text { STEM serta kurangnya } \\
\text { fasilitas yang ada di sekolah, } \\
\text { sehingga hal-hal inilah yang } \\
\text { menjadikan STEM menjadi } \\
\text { hal yang sedikit tabu untuk } \\
\text { para guru di beberapa wilayah } \\
\text { tertentu. }\end{array}$ \\
\hline SMA PGRI Cicalengka & 3 & 1 & 2 & 2 & 1 & 1 & 2 & 2 & 1 & 2 & 2 & 3 & 3 & 1 & 1 & 1 & $\begin{array}{l}\text { Jika dilihat dari kurikulum } \\
\text { nasional yang sangat padat } \\
\text { dalam jangka waktu satu } \\
\text { tahun, STEM mungkin } \\
\text { kurang cocok jika diterapkan } \\
\text { di sekolah dengan ekonomi } \\
\text { menengah ke bawh seperti di } \\
\text { sekolah yang saya ampu. } \\
\text { Selain keterbatasan tidak } \\
\text { adanya lab, dan kecakapan } \\
\text { literasi siswa yang jauh dari } \\
\text { kata cakap. Kemampuan } \\
\text { perhitungan siswa dan } \\
\text { kemampuan siswa dalam }\end{array}$ \\
\hline
\end{tabular}




\begin{tabular}{|c|c|c|c|c|c|c|c|c|c|c|c|c|c|c|c|c|c|}
\hline & & & & & & & & & & & & & & & & & $\begin{array}{l}\text { memahami pelajaran sangat } \\
\text { minim. Namun untuk } \\
\text { beberapa sekolah STEM } \\
\text { sebenarnya memenuhi kriteria } \\
\text { standar kutikulum yangctelah } \\
\text { ditetapkan pemerintah. } \\
\text { Sangat efektif untuk } \\
\text { meringkas projek siswa } \\
\text { menjadi lebih sederhana } \\
\text { untuk banyak mata pelajaran }\end{array}$ \\
\hline $\begin{array}{l}\text { SMK Negeri } 7 \\
\text { Baleendah }\end{array}$ & 2 & 3 & 2 & 2 & 3 & 3 & 3 & 4 & 3 & 3 & 3 & 3 & 3 & 2 & 3 & 4 & $\begin{array}{l}\text { Sudah bagus, tetapi karena } \\
\text { diserahkan kembali ke } \\
\text { masing-masing guru, } \\
\text { sehingga terjadinya } \\
\text { ketidakseragaman. } \\
\text { Kedepannya harus diadakan } \\
\text { pelatihan, agar guru } \\
\text { memahami semuanya. }\end{array}$ \\
\hline SMAN 1 Garut & 1 & 1 & 2 & 4 & 3 & 3 & 3 & 4 & 4 & 4 & 3 & 4 & 3 & 3 & 3 & 4 & $\begin{array}{l}\text { Pemerintah telah mendukung } \\
\text { dan memfasilitasi pendidikan } \\
\text { STEM terhadap kurikulum } \\
\text { nasional }\end{array}$ \\
\hline $\begin{array}{l}\text { SMAN } 1 \text { Cikembar } \\
\text { Sukabumi }\end{array}$ & 3 & 1 & 2 & 4 & 2 & 2 & 2 & 2 & 2 & 3 & 3 & 3 & 3 & 2 & 3 & 3 & $\begin{array}{l}\text { Pemerintah belum } \\
\text { sepenuhnya mendorong guru } \\
\text { untuk menggunakan STEM } \\
\text { dalam pembelajaran. Namun } \\
\text { pemerintah melalui } \\
\text { kebijakannya telah } \\
\text { melakukan langkah kecil ke } \\
\text { arah itu. }\end{array}$ \\
\hline SMAN 1 Garut & 2 & 1 & 2 & 4 & 2 & 3 & 3 & 3 & 3 & 3 & 4 & 4 & 4 & 3 & 3 & 3 & $\begin{array}{l}\text { Pemerintah masih setengah- } \\
\text { setengah dalam } \\
\text { mengaplikasikan STEM di } \\
\text { SMA, sehingga guru SMA }\end{array}$ \\
\hline
\end{tabular}




\begin{tabular}{|c|c|c|c|c|c|c|c|c|c|c|c|c|c|c|c|c|c|}
\hline & & & & & & & & & & & & & & & & & $\begin{array}{l}\text { masih kekurangan } \\
\text { sumberdaya dalam } \\
\text { memberikan STEM dibaetiap } \\
\text { pertemuan/pembelajaran. } \\
\text { Tidak seperti di SMK. }\end{array}$ \\
\hline SMAN 17 Garut & 1 & 1 & 2 & 4 & 1 & 1 & 2 & 1 & 1 & 1 & 3 & 3 & 3 & 1 & 2 & 2 & $\begin{array}{l}\text { secara konsep STEM sudah } \\
\text { masuk ke kurikulum, tetapi } \\
\text { dalam pelaksanaan tidak } \\
\text { sesederhana itu, materi } \\
\text { tuntutan kurikulum yang } \\
\text { terlalu banyak sehingga guru } \\
\text { di kejar target untuk tuntas }\end{array}$ \\
\hline SMAN 3 Bandung & 3 & 1 & 2 & 4 & 2 & 3 & 3 & 3 & 3 & 2 & 3 & 3 & 4 & 2 & 3 & 4 & $\begin{array}{l}\text { Pemerintah belum } \\
\text { sepenuhnya mengintegrasikan } \\
\text { STEM pada kuirkulum } \\
\text { nasional }\end{array}$ \\
\hline $\begin{array}{l}\text { SMP KARTIKA XIX-2 } \\
\text { BANDUNG }\end{array}$ & 2 & 4 & 1 & 2 & 2 & 2 & 3 & 2 & 2 & 2 & 3 & 3 & 3 & 2 & 2 & 2 & $\begin{array}{l}\text { Di sekolah tempat saya } \\
\text { mengajar sekarang stem } \\
\text { belum digunakan dalam } \\
\text { pembelajaran di kelas, masih } \\
\text { berupa ekstrakulikuler saja. } \\
\text { Di beberapa sekolah juga } \\
\text { sama. Jadi sepertinya perlu } \\
\text { ditingkatkan lagi pelatihan } \\
\text { mengenai stem yg bersumber } \\
\text { secara resmi dari pemerintah/ } \\
\text { dinas pendidikan }\end{array}$ \\
\hline SMAN 1 Garut & 1 & 2 & 2 & 3 & 3 & 3 & 2 & 3 & 3 & 3 & 3 & 3 & 3 & 3 & 4 & 4 & $\begin{array}{l}\text { Di Indonesia, reformasi } \\
\text { kurikulum persekolahan } \\
\text { sudah diarahkan untuk } \\
\text { membekali peserta didik pada } \\
\text { karakteristik warga negara } \\
\text { abad 21, namun khususnya } \\
\text { kurikulum untuk mata }\end{array}$ \\
\hline
\end{tabular}




\begin{tabular}{|c|c|c|c|c|c|c|c|c|c|c|c|c|c|c|c|c|c|}
\hline & & & & & & & & & & & & & & & & & $\begin{array}{l}\text { pelajaran sains belum secara } \\
\text { eksplisit mengintegrasikan } \\
\text { STEM. Walaupun demikian, } \\
\text { kurikulum nasional } \\
\text { (Kurikulum 2013) memiliki } \\
\text { semangat yang mendukung } \\
\text { para guru dan sekolah untuk } \\
\text { mengeksplorasi dan } \\
\text { menerapkan STEM sebagai } \\
\text { pendekatan pembelajaran } \\
\text { melalui penggunaan model } \\
\text { pembelajaran berbasis proyek } \\
\text { (PJBL), atau model } \\
\text { pembelajaran lainnya, seperti } \\
\text { siklus belajar 5E dan LOI } \\
\text { (Level of Inquiry). }\end{array}$ \\
\hline SMAN 1 GARUT & 3 & 1 & 2 & 4 & 2 & 2 & 3 & 2 & 2 & 2 & 1 & 1 & 1 & 2 & 4 & 4 & $\begin{array}{l}\text { pemerintah sudah } \\
\text { mengintegrasikan pendidikan } \\
\text { stem terhadap kurikulum } \\
\text { akan tetapi pemahaman guru } \\
\text { mengenai STEM harus } \\
\text { ditingkatkan }\end{array}$ \\
\hline SMAN 2 LEMBANG & 3 & 4 & 2 & 2 & 2 & 3 & 3 & 2 & 2 & 2 & 3 & 3 & 3 & 3 & 2 & 2 & $\begin{array}{l}\text { Di Indonesia belum bisa } \\
\text { diterapkan pembelajaran } \\
\text { STEM karena banyak hal } \\
\text { pertama kesiapan peserta } \\
\text { didik yang terbiasa dari SD } \\
\text { selalu diauapi oleh guru dan } \\
\text { guru selalu dibebankan } \\
\text { dengan harusnya pencapaian } \\
\text { kurikulum nasional yang } \\
\text { dimana guru sulit } \\
\text { berkolaborasi dengan mata } \\
\text { pelajaran lain }\end{array}$ \\
\hline
\end{tabular}




\begin{tabular}{|c|c|c|c|c|c|c|c|c|c|c|c|c|c|c|c|c|c|}
\hline SMAN 2 LEMBANG & 3 & 1 & 2 & 4 & 2 & 2 & 3 & 2 & 2 & 2 & 3 & 3 & 3 & 2 & 2 & 2 & $\begin{array}{l}\text { Di lapangan peran pemerintah } \\
\text { blm sepenuhnya } \\
\text { mengintegrasikan STEM dlm } \\
\text { kurikulum Nasional..baru } \\
\text { sebatas mendiklat guru2 nya } \\
\text { saja }\end{array}$ \\
\hline SMA Kharisma Bangsa & 3 & 1 & 2 & 1 & 2 & 3 & 3 & 3 & 3 & 3 & 3 & 3 & 3 & 2 & 3 & 3 & $\begin{array}{l}\text { Sejauh ini pendidikan STEM } \\
\text { masih perlu pengembangan } \\
\text { lebih dalam. Karena beberapa } \\
\text { topik di masing-masing } \\
\text { subjek yang cukup sulit jika } \\
\text { diintegrasikan dengan bidang } \\
\text { lain }\end{array}$ \\
\hline SMAN 4 Cimahi & 3 & 1 & 2 & 2 & 2 & 2 & 2 & 2 & 2 & 3 & 3 & 3 & 3 & 2 & 3 & 3 & $\begin{array}{l}\text { Kurikulum nasional sudah } \\
\text { sangat menunjang pendidikan } \\
\text { STEM di dalam } \\
\text { pembelajaran. Hanya jika } \\
\text { menggunakan STEM waktu } \\
\text { yg dibutuhkan sangat banyak } \\
\text { sedangkan materi peljaran } \\
\text { sangat banyak dan padat. } \\
\text { Untuk mengakses informasi, } \\
\text { terkendala d beberapa siswa } \\
\text { yg tidak.memiliki handphone } \\
\text { sehingga kesulitan mencari } \\
\text { informasi }\end{array}$ \\
\hline SMKN 6 Bandung & 3 & 1 & 2 & 4 & 2 & 2 & 2 & 2 & 2 & 2 & 3 & 3 & 3 & 2 & 2 & 2 & $\begin{array}{l}\text { Di Indonesia, reformasi } \\
\text { kurikulum persekolahan } \\
\text { sudah diarahkan untuk } \\
\text { membekali peserta didik pada } \\
\text { karakteristik warga negara } \\
\text { abad 21, namun khususnya } \\
\text { kurikulum untuk mata } \\
\text { pelajaran sains belum secara }\end{array}$ \\
\hline
\end{tabular}




\begin{tabular}{|c|c|c|c|c|c|c|c|c|c|c|c|c|c|c|c|c|c|}
\hline & & & & & & & & & & & & & & & & & $\begin{array}{l}\text { eksplisit mengintegrasikan } \\
\text { STEM. Walaupun demikian, } \\
\text { kurikulum nasional } \\
\text { (Kurikulum 2013) memiliki } \\
\text { semangat yang mendukung } \\
\text { para guru dan sekolah untuk } \\
\text { mengeksplorasi dan } \\
\text { menerapkan STEM sebagai } \\
\text { pendekatan pembelajaran } \\
\text { melalui penggunaan model } \\
\text { pembelajaran berbasis proyek } \\
\text { (PJBL), atau model } \\
\text { pembelajaran lainnya, seperti } \\
\text { siklus belajar 5E dan LOI } \\
\text { (Level of Inquiry). }\end{array}$ \\
\hline $\begin{array}{c}\text { SMA NEGERI } 1 \\
\text { GARUT }\end{array}$ & 1 & 2 & 2 & 2 & 3 & 2 & 3 & 3 & 3 & 3 & 3 & 3 & 3 & 2 & 3 & 3 & $\begin{array}{l}\text { Dengan cara sistematik } \\
\text { menyiapkan siswa } \\
\text { mengembangkan } \\
\text { pengetahuan, keterampilan } \\
\text { dan sikap yang } \\
\text { dipersyaratkan dunia kerja } \\
\text { Abad ke-21, sebagaimana } \\
\text { diwujudkan dalam } \\
\text { Pendidikan STEM. Untuk } \\
\text { mengatasi hal tersebut } \\
\text { Pendidikan dengan } \\
\text { pendekatan STEM bisa } \\
\text { menjadi kunci bagi } \\
\text { menciptakan generasi penerus } \\
\text { bangsa yang mampu bersaing } \\
\text { di kancah global. Oleh sebab } \\
\text { itu, Pendidikan STEM perlu } \\
\text { menjadi kerangka-rujukan }\end{array}$ \\
\hline
\end{tabular}




\begin{tabular}{|c|c|c|c|c|c|c|c|c|c|c|c|c|c|c|c|c|c|}
\hline & & & & & & & & & & & & & & & & & $\begin{array}{l}\text { bagi proses pendidikan di } \\
\text { Indonesia ke depan. }\end{array}$ \\
\hline SMKN 12 GARUT & 3 & 1 & 2 & 4 & 2 & 2 & 2 & 2 & 3 & 2 & 3 & 3 & 3 & 2 & 3 & 3 & Belum maksimal \\
\hline SMPN 1 Sumber & 2 & 1 & 1 & 1 & 2 & 3 & 3 & 2 & 3 & 2 & 2 & 3 & 3 & 3 & 3 & 3 & $\begin{array}{l}\text { STEM dan kurikulum masih } \\
\text { menjadi dua bagian yang } \\
\text { terpisah. STEM hanya } \\
\text { populer pada topik-topik } \\
\text { tertentu spt membuat } \\
\text { jembatan, robotik, desain } \\
\text { pesawat. Antara STEM dan } \\
\text { kurnas belum ada integrasi yg } \\
\text { menyeluruh menurut saya. } \\
\text { STEM mungkin baru hanya } \\
\text { sebatas ekstrakurikuler atau } \\
\text { sebagai ice breaking, belum } \\
\text { diselaraskan dg setiap capaian } \\
\text { KD dalam pelajaran. }\end{array}$ \\
\hline $\begin{array}{l}\text { SMP Kartika XIX-1 } \\
\text { Bandung }\end{array}$ & 3 & 1 & 1 & 2 & 2 & 2 & 2 & 2 & 2 & 1 & 3 & 3 & 3 & 2 & 2 & 1 & $\begin{array}{l}\text { Tentu bertahap, karena } \\
\text { kondisi di lapangan banyak } \\
\text { guru yang belum mengenal } \\
\text { dengan baik apa itu STEM } \\
\text { dan bagaimana menerapkan } \\
\text { STEM dalam suatu } \\
\text { pembelajaran. Sehingga } \\
\text { untuk saat ini, sosialisasi } \\
\text { pendekatan STEM bagi guru } \\
\text { masih harus di optimalkan. } \\
\text { Setelah sebagaian besar guru } \\
\text { mengenal STEM dengan baik } \\
\text { dan mampu melaksanakan } \\
\text { pembelajaran dengan } \\
\text { pendekatan STEM. Barulah } \\
\text { pemerintah bisa } \\
\text { melakukannintegrasi STEM }\end{array}$ \\
\hline
\end{tabular}




\begin{tabular}{|c|c|c|c|c|c|c|c|c|c|c|c|c|c|c|c|c|c|}
\hline & & & & & & & & & & & & & & & & & $\begin{array}{l}\text { terhadap kurikulum nasional } \\
\text { dengan melihat contoh negara } \\
\text { lain yang sudah berhasil } \\
\text { melakukan hal tersebut di } \\
\text { negara mereka }\end{array}$ \\
\hline SMP PGRI 2 CISOLOK & 3 & 1 & 1 & 1 & 2 & 3 & 4 & 3 & 3 & 2 & 3 & 3 & 3 & 2 & 3 & 3 & $\begin{array}{l}\text { Pendidikan STEM } \\
\text { diintegrasikan dengan } \\
\text { kurikulum nasional untuk } \\
\text { meningkatkan kemampuan } \\
\text { SDM kita agar sesuai dengan } \\
\text { tuntutan kompetensi abad } 21\end{array}$ \\
\hline Heni mulyani & 2 & 4 & 2 & 4 & 2 & 3 & 3 & 3 & 3 & 3 & 3 & 3 & 3 & 3 & 2 & 3 & $\begin{array}{l}\text { Rancangan boleh bagus, tapi } \\
\text { kembali lagi k standar } \\
\text { kemampuan siswa d sekolah } \\
\text { masing2. }\end{array}$ \\
\hline $\begin{array}{l}\text { SMK Ciledug Al } \\
\text { Musaddadiyah }\end{array}$ & 1 & 2 & 2 & 2 & 3 & 3 & 3 & 3 & 3 & 2 & 3 & 3 & 4 & 4 & 4 & 3 & $\begin{array}{l}\text { Cukup baik untuk } \\
\text { pengembangan keterampilan } \\
\text { keterampilan yang akan } \\
\text { berguna bagi anak utk belajar, } \\
\text { bersaing dikehidupan } \\
\text { mendatang semisal dalam } \\
\text { sebuah perkerjaan namun } \\
\text { memang butuh pengkajian } \\
\text { lebih mendalam mengingat } \\
\text { kultur dan keadaan sosial } \\
\text { ekonomi yg berbeda dari tiap- } \\
\text { tiap siswa. }\end{array}$ \\
\hline SMP Swasta Pelita Hati & 3 & 1 & 1 & 3 & 2 & 2 & 3 & 3 & 2 & 2 & 3 & 3 & 3 & 2 & 2 & 2 & $\begin{array}{l}\text { Pemerintah merancang } \\
\text { pembelajaran dalam } \\
\text { kurikulum nasional yang } \\
\text { mengembangkan kompetensi } \\
\text { siswa melalui berbagai } \\
\text { keterampilan yang harus }\end{array}$ \\
\hline
\end{tabular}




\begin{tabular}{|c|c|c|c|c|c|c|c|c|c|c|c|c|c|c|c|c|c|}
\hline & & & & & & & & & & & & & & & & & $\begin{array}{l}\text { dikuasai oleh siswa melalui } \\
\text { pembelajaran }\end{array}$ \\
\hline SMP N 2 Sidareja & 2 & 1 & 1 & 2 & 3 & 3 & 3 & 3 & 3 & 3 & 4 & 3 & 4 & 3 & 3 & 3 & $\begin{array}{l}\text { Pemerintah telah } \\
\text { mengembangkan kurikulum } \\
2013 \text { berbasis scientific } \\
\text { methode, yg artinya setiap } \\
\text { pembelajaran harus mengikuti } \\
\text { alur dr metode tersebut. } \\
\text { Sehingga menurut saya, } \\
\text { tinggal peran dari guru itu } \\
\text { sendiri untuk menerapkan } \\
\text { pembelajaran tersebut. } \\
\text { Namun kendalanya adalah, } \\
\text { sebagian besar guru masih } \\
\text { belum menguasai } \\
\text { pembelajaran berbasis } \\
\text { scintific, apalagi STEM, } \\
\text { maka dari itu, harus ada } \\
\text { upaya dalam meningkatkan } \\
\text { pengetahuan bagi guru } \\
\text { mengenai pembelajaran } \\
\text { scintific maupun STEM. }\end{array}$ \\
\hline $\begin{array}{l}\text { SMP Kartika XIX-2 } \\
\text { Bandung }\end{array}$ & 3 & 1 & 1 & 2 & 2 & 2 & 2 & 2 & 2 & 3 & 3 & 4 & 4 & 2 & 3 & 3 & $\begin{array}{l}\text { Dalam Kurikulum Nasional, } \\
\text { kompetensi dasar dari setiap } \\
\text { mata pelajaran STEM belum } \\
\text { disusun secara paralel } \\
\text { sehingga para guru kesulitan } \\
\text { untuk menemukan cross } \\
\text { cutting conceptnya. Selain } \\
\text { itu, muatan kurikulum yang } \\
\text { padat membuat pendekatan } \\
\text { STEM jarang dipilih karena } \\
\text { akan menghabiskan alokasi }\end{array}$ \\
\hline
\end{tabular}




\begin{tabular}{|c|c|c|c|c|c|c|c|c|c|c|c|c|c|c|c|c|c|}
\hline & & & & & & & & & & & & & & & & & $\begin{array}{l}\text { waktu pembelajaran yang } \\
\text { lebih banyak. }\end{array}$ \\
\hline $\begin{array}{c}\text { SMA AMANAH } \\
\text { MUHAMMDIYAH } \\
\text { KOTA } \\
\text { TASIKMALAYA }\end{array}$ & 3 & 1 & 2 & 2 & 2 & 2 & 2 & 3 & 3 & 2 & 4 & 4 & 4 & 1 & 2 & 1 & $\begin{array}{l}\text { Kurikulum di indonesia } \\
\text { sekarang belum terlalu } \\
\text { mengintegrasikan pendidikan } \\
\text { STEM tetapi hanya berfokus } \\
\text { pads level kognitif saja }\end{array}$ \\
\hline SMAN 1 GARUT & 2 & 1 & 2 & 4 & 2 & 2 & 2 & 4 & 4 & 3 & 4 & 4 & 4 & 3 & 3 & 3 & $\begin{array}{l}\text { Pemerintah mengintegrasikan } \\
\text { pendidikan STEM terhadap } \\
\text { kurikulum nasional dapat } \\
\text { terlihat di silabus, terutama } \\
\text { di KD, pembelajaran dan } \\
\text { sumber belajarnya. hanya } \\
\text { karena baru tahun ini tidak } \\
\text { ada ujian nasional jadi lebih } \\
\text { banyak pembelajaran } \\
\text { diarahkan untuk penguasaan } \\
\text { konsep. }\end{array}$ \\
\hline $\begin{array}{c}\text { Sekolah Kharisma } \\
\text { Bangsa }\end{array}$ & 3 & 1 & 2 & 1 & 2 & 2 & 3 & 3 & 3 & 2 & 3 & 4 & 4 & 3 & 3 & 2 & $\begin{array}{l}\text { Pemerintah berusaha } \\
\text { menerapkan STEM education } \\
\text { bahkan daritingkat sekolah } \\
\text { dasar dengan mendorong } \\
\text { peserta didik untuk memiliki } \\
\text { pola pikir problem solver, } \\
\text { innovator and berfikir logis. } \\
\text { Hanya saja masih butuh } \\
\text { waktu yang lama agar } \\
\text { kurikulum ini dapat terpatri } \\
\text { dan menunjukkan hasilnyang } \\
\text { significant. Saat ini saya } \\
\text { masih mendengar tanggapan } \\
\text { beberapa guru tentang } \\
\text { susahnya menerapkan STEM }\end{array}$ \\
\hline
\end{tabular}




\begin{tabular}{|c|c|c|c|c|c|c|c|c|c|c|c|c|c|c|c|c|c|}
\hline & & & & & & & & & & & & & & & & & $\begin{array}{l}\text { karena kebiasaan belajar yg } \\
\text { berbeda dari sebelumnya. }\end{array}$ \\
\hline SMP 3 Almuhajirin & 2 & 4 & 1 & 2 & 2 & 3 & 3 & 3 & 3 & 3 & 3 & 3 & 3 & 3 & 3 & 3 & $\begin{array}{l}\text { saya baru mengetahui tentang } \\
\text { STEM }\end{array}$ \\
\hline SMA BPI 2 & 3 & 1 & 2 & 2 & 2 & 3 & 2 & 4 & 3 & 3 & 4 & 4 & 4 & 2 & 2 & 3 & $\begin{array}{l}\text { Sejauh yang saya perhatikan } \\
\text { pemerintah sudah mulai } \\
\text { menyosialisasikan } \\
\text { pembelajaran stem kepada } \\
\text { guru dan siswa melalui } \\
\text { pendekatan Literasi dan } \\
\text { numerasi atau tematik }\end{array}$ \\
\hline SMA Santa Maria 2 & 1 & 1 & 2 & 2 & 2 & 3 & 3 & 3 & 4 & 4 & 3 & 4 & 3 & 2 & 3 & 3 & $\begin{array}{l}\text { Pendidikan STEM dalam } \\
\text { kurikulum nasional seolah } \\
\text { berdiri masing-masing tanpa } \\
\text { ada keterkaitan }\end{array}$ \\
\hline SMAN 1 Garut & 3 & 4 & 2 & 2 & 2 & 2 & 3 & 2 & 2 & 2 & 3 & 3 & 3 & 2 & 3 & 3 & $\begin{array}{l}\text { Belum terintegrasi } \\
\text { sepenuhnya karena kurangnya } \\
\text { pemahaman tentang STEM. }\end{array}$ \\
\hline $\begin{array}{l}\text { Sman } 1 \text { campaka } \\
\text { purwakarta }\end{array}$ & 2 & 1 & 2 & 2 & 3 & 2 & 3 & 3 & 2 & 2 & 3 & 3 & 3 & 2 & 2 & 2 & $\begin{array}{l}\text { Kurikulum } 2013 \text { yang } \\
\text { diterapkan di Indonesia } \\
\text { menurut saya sudah sejalan } \\
\text { dengan STEM, karena } \\
\text { perkembangan dunia } \\
\text { pendidikan sangat cepat, } \\
\text { karena itu Indonesia harus } \\
\text { menyesuaikan kurikulum agar } \\
\text { dapat bersaing di era global }\end{array}$ \\
\hline $\begin{array}{l}\text { SMK TI Garuda } \\
\text { Nusantara Cimahi }\end{array}$ & 2 & 1 & 2 & 2 & 2 & 3 & 3 & 2 & 3 & 3 & 3 & 3 & 3 & 2 & 3 & 3 & $\begin{array}{l}\text { Pendidikan STEM di } \\
\text { Indonesia masih menekankan } \\
\text { hanya pada pemahaman } \\
\text { materi tanpa memacu siswa } \\
\text { untuk melakukan penemuan } \\
\text { atau pengaplikasian konsep } \\
\text { dalam kehidupan. Hal ini }\end{array}$ \\
\hline
\end{tabular}




\begin{tabular}{|c|c|c|c|c|c|c|c|c|c|c|c|c|c|c|c|c|c|}
\hline & & & & & & & & & & & & & & & & & $\begin{array}{l}\text { dilihat dari banyaknya KD } \\
\text { pada silabus. }\end{array}$ \\
\hline SMA Negeri 1Garut & 3 & 1 & 2 & 4 & 2 & 2 & 3 & 2 & 2 & 3 & 4 & 3 & 4 & 3 & 3 & 3 & $\begin{array}{l}\text { pembelajaran dengan } \\
\text { pendekatan STEM dapat } \\
\text { melatih peserta didik untuk } \\
\text { menerapkan ilmu yang } \\
\text { dipelajari di sekolah dengan } \\
\text { fenomena yang terjadi dalam } \\
\text { dunia nyata, yang sudah } \\
\text { terintegrasi dalam Kurikulum } \\
\text { Nasional }\end{array}$ \\
\hline $\begin{array}{l}\text { SMK TI Garuda } \\
\text { Nusantara Cimahi }\end{array}$ & 2 & 3 & 2 & 3 & 3 & 4 & 4 & 3 & 3 & 3 & 4 & 4 & 4 & 3 & 3 & 3 & $\begin{array}{l}\text { Menurut saya, sejauh ini } \\
\text { karna teknologi semakin maju } \\
\text { dan banyak yang bisa di } \\
\text { kolaborasikan. Jadinya tidak } \\
\text { bermasalah untuk melakukan } \\
\text { integrsi terhadap kurikulum } \\
\text { nasional ke STEM. }\end{array}$ \\
\hline SMAN 1 Garut & 1 & 4 & 2 & 4 & 2 & 3 & 3 & 2 & 3 & 3 & 3 & 3 & 3 & 3 & 3 & 3 & $\begin{array}{l}\text { khususnya kurikulum untuk } \\
\text { mata pelajaran sains belum } \\
\text { secara eksplisit } \\
\text { mengintegrasikan STEM. } \\
\text { Walaupun demikian, } \\
\text { kurikulum nasional/kurtilas } \\
\text { memiliki semangat yang } \\
\text { mendukung para guru dan } \\
\text { sekolah untuk mengeksplorasi } \\
\text { dan menerapkan STEM } \\
\text { sebagai pendekatan } \\
\text { pembelajaran melalui } \\
\text { penggunaan model } \\
\text { pembelajaran berbasis proyek } \\
\text { (PJBL), atau model } \\
\text { pembelajaran lainnya }\end{array}$ \\
\hline
\end{tabular}




\begin{tabular}{|c|c|c|c|c|c|c|c|c|c|c|c|c|c|c|c|c|c|}
\hline SMA N 6 Bandung & 3 & 4 & 2 & 1 & 2 & 2 & 2 & 1 & 1 & 2 & 2 & 2 & 3 & 2 & 2 & 2 & $\begin{array}{l}\text { Belum sepenuhnya } \\
\text { teraplikasikan di lapangan. }\end{array}$ \\
\hline $\begin{array}{c}\text { SMK KESEHATAN } \\
\text { BHAKTI KENCANA } \\
\text { SUBANG }\end{array}$ & 2 & 1 & 2 & 3 & 2 & 3 & 2 & 3 & 2 & 3 & 3 & 3 & 3 & 2 & 2 & 3 & $\begin{array}{l}\text { Sudah cukup baik, hanya saja } \\
\text { belum ada pemerataan } \\
\text { pemahaman tentang STEM } \\
\text { sehingga masih terdapat } \\
\text { banyak kendala dalam } \\
\text { pelaksanaan kegiatan berbasis } \\
\text { STEM. }\end{array}$ \\
\hline Sman 6 Bandung & 3 & 1 & 2 & 4 & 2 & 2 & 3 & 3 & 3 & 2 & 3 & 3 & 3 & 2 & 2 & 3 & $\begin{array}{l}\text { Sosialisasi dan pelatihan guru } \\
\text { masih kurang }\end{array}$ \\
\hline SMAN 9 Bandung & 3 & 1 & 2 & 1 & 3 & 2 & 3 & 2 & 2 & 3 & 4 & 4 & 4 & 4 & 4 & 3 & $\begin{array}{l}\text { Saya rasa dalam kurikulum } \\
\text { pemerintah kurang } \\
\text { menekanakan STEM } \\
\text { hubungannya secara nyata } \\
\text { serta dalam ilmu kimia yg } \\
\text { saya ajarkan tidak semuanya } \\
\text { ada penerapan teknologinya }\end{array}$ \\
\hline SMAN 9 BANDUNG & 3 & 1 & 2 & 1 & 1 & 2 & 3 & 3 & 3 & 2 & 3 & 3 & 3 & 1 & 3 & 2 & $\begin{array}{l}\text { Menurut saya pendidikan } \\
\text { stem di indonesia blm } \\
\text { diintegrqsikan secara } \\
\text { maksimal dalam kurikulum } \\
\text { nasional dan juga penerapan } \\
\text { pendidikan stem masih sulit } \\
\text { di terapkan }\end{array}$ \\
\hline SMAN 5 BANDUNG & 3 & 1 & 2 & 2 & 2 & 2 & 3 & 2 & 2 & 3 & 3 & 3 & 2 & 2 & 2 & 2 & $\begin{array}{l}\text { Pemerintah dalam } \\
\text { mengintegrasikan pendidikan } \\
\text { STEM terhadap kurnas masih } \\
\text { seperti sebuah proyek, yg } \\
\text { selama ini sebelum booming } \\
\text { istilah stem sy sdh pernah } \\
\text { mengenal istilah stm, lalu pd } \\
\text { thn } 2019 \text { sy mengikuti } \\
\text { pelatihan stem dari MGMP }\end{array}$ \\
\hline
\end{tabular}




\begin{tabular}{|c|c|c|c|c|c|c|c|c|c|c|c|c|c|c|c|c|c|}
\hline & & & & & & & & & & & & & & & & & $\begin{array}{l}\text { KIMIA KOTA BANDUNG } \\
\text { dibawah bimbingan P4TK } \\
\text { IPA. Dari sini sy mencoba } \\
\text { memilih beberapa KI dan KD } \\
\text { pd kls } 10,11 \text {, dan } 12 \text { untuk di } \\
\text { coba diterapkan pd } \\
\text { pembelajaran agar dapat } \\
\text { membantu menjembatani } \\
\text { penguatan konsep kimia dan } \\
\text { aplikasi kimia dalam } \\
\text { kehidupan sehari-hari yg } \\
\text { selama ini seperti terkotak- } \\
\text { kotak antara apa yg dipelajari } \\
\text { d kelas dg kenyataan, akan } \\
\text { tetapi dukungan dari } \\
\text { pemerintah terhadap SDM } \\
\text { guru dan bantuan dana } \\
\text { sarpras u/ mengintegrasikan } \\
\text { pendidikan STEM terhadap } \\
\text { kurnas masih kurang } \\
\text { perhatian. }\end{array}$ \\
\hline Sma kartika xix-3 & 2 & 4 & 2 & 4 & 2 & 2 & 3 & 2 & 3 & 3 & 3 & 1 & 3 & 2 & 3 & 3 & $\begin{array}{l}\text { Pemerintah sudah merancang } \\
\text { integrasi pendidikan stem tapi } \\
\text { sk, kd belum tepat } \\
\text { penenpatan nya di pelajaran } \\
\text { yang menggunakan stem, } \\
\text { misal kd matematika kls x } \\
\text { semester } 2 \text {, sesuainya dengan } \\
\text { kd di fisika namun di sem } 1\end{array}$ \\
\hline $\begin{array}{c}\text { SMA Pasundan } 8 \\
\text { Bandung }\end{array}$ & 3 & 1 & 2 & 1 & 1 & 2 & 2 & 2 & 1 & 2 & 3 & 3 & 3 & 1 & 2 & 2 & $\begin{array}{l}\text { Pendidikan STEM bagus } \\
\text { digunakan pada pembelajaran } \\
\text { berbasis kurikulum nasional, } \\
\text { tetapi harus diperhatikan } \\
\text { keadaan siswa yang masih }\end{array}$ \\
\hline
\end{tabular}




\begin{tabular}{|c|c|c|c|c|c|c|c|c|c|c|c|c|c|c|c|c|c|}
\hline & & & & & & & & & & & & & & & & & $\begin{array}{l}\text { banyak kurang terbiasa } \\
\text { dengan pendidikan STEM }\end{array}$ \\
\hline SMA Kartiaka XIX-3 & 3 & 1 & 2 & 2 & 2 & 3 & 2 & 2 & 2 & 2 & 3 & 3 & 3 & 2 & 3 & 3 & $\begin{array}{l}\text { panduan pembuatan RPP } \\
\text { yang diberikan dianjurkan } \\
\text { menekankan pada proses } \\
\text { keterampilan berpikir kritis, } \\
\text { kreatif, dan inovatif }\end{array}$ \\
\hline $\begin{array}{l}\text { SMK NEGERI } 11 \\
\text { GARUT }\end{array}$ & 2 & 2 & 2 & 4 & 3 & 2 & 3 & 3 & 3 & 3 & 3 & 3 & 3 & 3 & 3 & 3 & Kurang epektif \\
\hline SMK Negeri 2 Garut & 1 & 4 & 2 & 4 & 3 & 3 & 2 & 3 & 3 & 3 & 3 & 4 & 4 & 3 & 3 & 3 & $\begin{array}{l}\text { Kurikulum yang berlaku di } \\
\text { Indonesia dengan mengacu } \\
\text { pada perubahan kurikulum } \\
\text { tahun } 2013 \text { yang terus } \\
\text { mengalami revisi samapai } \\
\text { tahun } 2018\end{array}$ \\
\hline $\begin{array}{l}\text { SMA KARTIKAS XIX- } \\
3 \text { BANDUNG }\end{array}$ & 2 & 2 & 2 & 1 & 3 & 3 & 3 & 3 & 3 & 3 & 3 & 3 & 3 & 3 & 3 & 3 & $\begin{array}{l}\text { pemerintah sebaiknya sudah } \\
\text { memiliki rancangan ataupun } \\
\text { rencana yang matang untuk } \\
\text { meningkatkan kompetensi } \\
\text { guru dalam menggunakan } \\
\text { Information and } \\
\text { Communications Technology } \\
\text { (ICT) pada proses } \\
\text { pembelajaran. }\end{array}$ \\
\hline $\begin{array}{l}\text { SMK CILEDUG AL } \\
\text { MUSADDADIYAH }\end{array}$ & 3 & 4 & 2 & 1 & 2 & 3 & 3 & 2 & 3 & 3 & 3 & 4 & 3 & 3 & 3 & 3 & $\begin{array}{l}\text { Pemerintah cukup } \\
\text { mendukung dengan adanya } \\
\text { ketentuan ketentuan baru } \\
\text { terkait pembelajaran dgn } \\
\text { kurikulum nasional }\end{array}$ \\
\hline SMKN 2 GARUT & 1 & 2 & 2 & 4 & 3 & 3 & 2 & 4 & 4 & 3 & 4 & 3 & 3 & 3 & 3 & 4 & $\begin{array}{l}\text { Pada materi yg di sajikan di } \\
\text { haruskan sudah berbasiskan } \\
\text { hots }\end{array}$ \\
\hline MTs. Al- Rohmah Garut & 3 & 4 & 1 & 4 & 2 & 2 & 2 & 2 & 2 & 2 & 3 & 4 & 3 & 2 & 2 & 2 & $\begin{array}{l}\text { Kurang sosialisasi dan } \\
\text { pemerataan }\end{array}$ \\
\hline
\end{tabular}




\begin{tabular}{|c|c|c|c|c|c|c|c|c|c|c|c|c|c|c|c|c|c|}
\hline $\begin{array}{l}\text { SMAIT MIFTAHUL } \\
\text { KHOIR BANDUNG }\end{array}$ & 3 & 1 & 2 & 2 & 2 & 2 & 2 & 2 & 2 & 2 & 3 & 3 & 4 & 3 & 4 & 3 & $\begin{array}{l}\text { Untuk saat ini pemerintah } \\
\text { dirasa belum secara jelas Dan } \\
\text { nyata dalam mengintruksikan } \\
\text { Pendidikan STEM terhadap } \\
\text { kurikulum Nasional. }\end{array}$ \\
\hline SMPN 23 BANDUNG & 3 & 1 & 1 & 4 & 2 & 2 & 3 & 3 & 2 & 3 & 3 & 3 & 3 & 3 & 2 & 2 & $\begin{array}{l}\text { Di tingkat SMP masih banyak } \\
\text { materi yang belum bisa di } \\
\text { integrasikan sehingga } \\
\text { implementasi STEM terhadap } \\
\text { pelaksanaan kurikulum } \\
\text { Nasional masih sulit } \\
\text { dilaksanakan }\end{array}$ \\
\hline Smpn 2 banjaran & 2 & 1 & 1 & 1 & 2 & 3 & 3 & 2 & 2 & 3 & 4 & 4 & 4 & 3 & 4 & 3 & Sudah bagus \\
\hline SMP Generasi madani & 1 & 1 & 1 & 1 & 3 & 3 & 3 & 3 & 3 & 4 & 4 & 4 & 4 & 3 & 3 & 3 & $\begin{array}{l}\text { Penting nya pembelajaran } \\
\text { STEM untuk meningkatkan } \\
\text { kemampuan sains, IPA dan } \\
\text { teknologi }\end{array}$ \\
\hline SMA XIX Kartika & 4 & 1 & 2 & 1 & 1 & 2 & 2 & 2 & 2 & 1 & 3 & 3 & 3 & 2 & 2 & 2 & $\begin{array}{l}\text { Dengan adanya merdeka } \\
\text { belajar }\end{array}$ \\
\hline $\begin{array}{l}\text { SMA Kartika XIX-2 } \\
\text { Bandung }\end{array}$ & 2 & 1 & 2 & 1 & 2 & 3 & 2 & 3 & 2 & 2 & 3 & 3 & 3 & 2 & 1 & 2 & Melalui silabus \\
\hline $\begin{array}{l}\text { SMK TI GARUDA } \\
\text { NUSANTARA } \\
\text { CIMAHI } \\
\end{array}$ & 2 & 2 & 2 & 3 & 2 & 2 & 3 & 2 & 2 & 2 & 3 & 3 & 3 & 3 & 4 & 3 & Belum tau \\
\hline SMAN 1 Baleendah & 3 & 1 & 2 & 1 & 2 & 3 & 3 & 2 & 3 & 3 & 3 & 3 & 3 & 2 & 3 & 3 & $\begin{array}{l}\text { Saat ini, pemerintah } \\
\text { mendukung sekolah untuk } \\
\text { mengeksplorasi dan } \\
\text { menerapkan STEM sebagai } \\
\text { pendekatan pembelajaran } \\
\text { dalam kurikulum nasional } \\
\text { walaupun belum secara } \\
\text { eksplisit sepenuhnya } \\
\text { mengintegrasikan STEM. } \\
\text { Walaupun demikian, }\end{array}$ \\
\hline
\end{tabular}




\begin{tabular}{|c|c|c|c|c|c|c|c|c|c|c|c|c|c|c|c|c|c|}
\hline & & & & & & & & & & & & & & & & & $\begin{array}{l}\text { pemerintah sudah banyak } \\
\text { mengadakan dan } \\
\text { memfasilitasi kegiatan dalam } \\
\text { rangka mengintegrasikan } \\
\text { STEM dalam kurikulum } \\
\text { nasional di mulai dari segi } \\
\text { perencanaan pembelajaran, } \\
\text { pelaksanaan pembelajaran } \\
\text { hingga proses penilaian. }\end{array}$ \\
\hline SMAN 8 BANDUNG & 3 & 1 & 2 & 4 & 2 & 3 & 3 & 2 & 3 & 3 & 4 & 3 & 4 & 4 & 4 & 4 & $\begin{array}{l}\text { Pembelajaran dengan metode } \\
\text { pembelajaran STEM, } \\
\text { merupakan salah satu metode } \\
\text { yang sesuai dengan proses } \\
\text { pembelajaran abad 21, yg } \\
\text { bercirikan peserta didik } \\
\text { mempunyai kompetensi 4C } \\
\text { (critical thinking, } \\
\text { collaborative, creativity n } \\
\text { communicative). Maka } \\
\text { pemerintah menerapkan } \\
\text { metode STEM pada } \\
\text { rancangan pembelajaran. Hal } \\
\text { ini disosialisasikan melalui } \\
\text { kegiatan workshop, bimtek, } \\
\text { iht dsb. }\end{array}$ \\
\hline $\begin{array}{l}\text { SMAN } 6 \text { KOTA } \\
\text { BANDUNG }\end{array}$ & 2 & 1 & 2 & 1 & 2 & 3 & 2 & 3 & 4 & 1 & 4 & 3 & 4 & 1 & 3 & 4 & $\begin{array}{l}\text { Integrasi stem dengan } \\
\text { kurikulum nasional di } \\
\text { indonesia dapat dilihat dari } \\
\text { kurikulum } 2013 \text { yg berbasis } \\
\text { kompetensi yang berfokus } \\
\text { pada mengintegrasikan } \\
\text { kompetensi sikap, } \\
\text { pengetahuan, dan } \\
\text { keterampilan. Dengan adanya }\end{array}$ \\
\hline
\end{tabular}




\begin{tabular}{|c|c|c|c|c|c|c|c|c|c|c|c|c|c|c|c|c|c|}
\hline & & & & & & & & & & & & & & & & & $\begin{array}{l}\text { tujuan untuk menghasilkan } \\
\text { lulusan lulusan yg } \\
\text { berkompetensi maksimal } \\
\text { tersebut, KD juga sudah } \\
\text { dirancang sedemikian rupa } \\
\text { untuk menjadi acuan } \\
\text { perencanaan pembelajaran yg } \\
\text { menerapkan pendekatan } \\
\text { keterampilan proses sains } \\
\text { secara maksimal untuk } \\
\text { memperoleh pengetahuan } \\
\text { serta mengkreasi produk }\end{array}$ \\
\hline SMAN 1 Garut & 3 & 4 & 2 & 4 & 2 & 3 & 3 & 2 & 2 & 2 & 3 & 3 & 3 & 2 & 3 & 2 & $\begin{array}{l}\text { Dengan adanya pelatihan } \\
\text { pembelajaran mengenai stem }\end{array}$ \\
\hline SMAN 8 BANDUNG & 2 & 4 & 2 & 2 & 2 & 2 & 3 & 3 & 3 & 3 & 3 & 3 & 3 & 2 & 3 & 3 & $\begin{array}{l}\text { Jika berdasarkan kurikulum } \\
\text { tidak terlihat jelas tentang } \\
\text { pengintegrasian pendidikan } \\
\text { STEM. Melainkan gurulah } \\
\text { yang mendesainnya sesuai } \\
\text { kebutuhan dan kondisi } \\
\text { kesiapan sekolah, apalagi jika } \\
\text { nantinya ada kolaborasi antar } \\
\text { mata pelajaran. }\end{array}$ \\
\hline Darul Hikam & 2 & 1 & 1 & 4 & 3 & 3 & 3 & 3 & 3 & 3 & 3 & 3 & 3 & 3 & 3 & 3 & $\begin{array}{l}\text { Pemerintah sudah merancang } \\
\text { kurikulum untuk } \\
\text { mengembangkan STEM } \\
\text { walaupun pada } \\
\text { pelaksanaannya, guru harus } \\
\text { mampu merancang dan } \\
\text { mengimplementasikan } \\
\text { pelaksanaan pembelajaran } \\
\text { STEM }\end{array}$ \\
\hline $\begin{array}{c}\text { SMAN 1 } \\
\text { PURWAKARTA }\end{array}$ & 1 & 4 & 2 & 1 & 1 & 3 & 3 & 1 & 3 & 3 & 4 & 3 & 3 & 3 & 3 & 3 & $\begin{array}{l}\text { Menurut saya dalam } \\
\text { kurikulum 2013, STEM }\end{array}$ \\
\hline
\end{tabular}




\begin{tabular}{|c|c|c|c|c|c|c|c|c|c|c|c|c|c|c|c|c|c|}
\hline & & & & & & & & & & & & & & & & & $\begin{array}{l}\text { sudah direncanakan secara } \\
\text { baik. Namun kembali lagi, } \\
\text { pengaplikasiannya dalam } \\
\text { pembelajaran perlu diskusi } \\
\text { sesama guru mapel agar } \\
\text { terlaksana dengan baik. }\end{array}$ \\
\hline Bimbel & 2 & 1 & 2 & 1 & 3 & 3 & 3 & 3 & 3 & 2 & 4 & 4 & 3 & 3 & 3 & 3 & $\begin{array}{l}\text { Pemerintah secara ekspelit } \\
\text { menyebutkan bahwa } \\
\text { pembelajaran yang ada harus } \\
\text { dipadukan dengan teknologi } \\
\text { dan permasalahan yang ada } \\
\text { disekitar misalnya guru ipa } \\
\text { bisa mengangkat proses } \\
\text { pembelajaran dari kehidupan } \\
\text { nyata dalam proses } \\
\text { pembersihan noda pada baju } \\
\text { atau pencucian baju. }\end{array}$ \\
\hline $\begin{array}{l}\text { SMP Darul Hikam } \\
\text { Bandung }\end{array}$ & 2 & 4 & 1 & 2 & 2 & 2 & 3 & 2 & 2 & 4 & 3 & 3 & 3 & 2 & 3 & 3 & $\begin{array}{l}\text { Belum ada aturan resmi } \\
\text { mengenai pelaksanaan } \\
\text { integrasinya, adapun program } \\
\text { sosialisasi pemerintah } \\
\text { mengenai integrasi } \\
\text { pembelajaran stem baru } \\
\text { sampai pada tahap analisis } \\
\text { KD dan rancangan, namun } \\
\text { yang benar benar dibutuhkan } \\
\text { adalah panduan pokok dan } \\
\text { contoh materi stem untuk } \\
\text { setiap materi pokok yang } \\
\text { harus diajarkan }\end{array}$ \\
\hline Sman 15 garut & 4 & 1 & 2 & 4 & 2 & 2 & 3 & 3 & 2 & 2 & 4 & 3 & 3 & 3 & 4 & 4 & $\begin{array}{l}\text { Dunia pendidikan bersifat } \\
\text { dinamis sesuai dengan } \\
\text { perkembangan teknologi dan } \\
\text { industri sehingga sangat perlu }\end{array}$ \\
\hline
\end{tabular}




\begin{tabular}{|c|c|c|c|c|c|c|c|c|c|c|c|c|c|c|c|c|c|}
\hline & & & & & & & & & & & & & & & & & $\begin{array}{l}\text { untuk membuat suatu } \\
\text { kurikulum yang dapat } \\
\text { mengintegradikan stem } \\
\text { dengan kurikulum yang } \\
\text { sedang berjalan }\end{array}$ \\
\hline SMKN 12 Garut & 2 & 3 & 2 & 2 & 2 & 2 & 3 & 4 & 2 & 4 & 4 & 3 & 3 & 2 & 4 & 4 & $\begin{array}{l}\text { Harus adanya integrasi } \\
\text { kurikulum yang capaiannya } \\
\text { siswabkompenten setelah } \\
\text { pembelajaran }\end{array}$ \\
\hline SMKN 1 Cipongkor & 2 & 4 & 2 & 1 & 1 & 2 & 3 & 2 & 2 & 1 & 4 & 4 & 4 & 2 & 3 & 3 & $\begin{array}{l}\text { Pemerintah dapat } \\
\text { menyediakan kurikulum baru } \\
\text { yang mengintegrasikan } \\
\text { pendidikan STEM karena } \\
\text { pada saat ini siswa dituntut } \\
\text { untuk dapat menghadapi } \\
\text { perkembangan zaman }\end{array}$ \\
\hline $\begin{array}{l}\text { SMP Darul Hikam } \\
\text { Bandung }\end{array}$ & 2 & 4 & 1 & 2 & 2 & 3 & 3 & 3 & 3 & 3 & 3 & 3 & 3 & 3 & 3 & 3 & $\begin{array}{l}\text { Kurikulum Indonesia belum } \\
\text { berfokus pada implementasi } \\
\text { STEM. Tidak setiap daerah } \\
\text { dapat menyelenggaran KBM } \\
\text { berbasis STEM. Di Kota-kota } \\
\text { besar dan sekolah-sekolah } \\
\text { yang siap sudah dapat } \\
\text { melaksanakan STEM di } \\
\text { sekolahnya. Seperti di Kota } \\
\text { Bandung untuk tingkat SMP } \\
\text { sudah melaksanakan TOT } \\
\text { dan pemilihan Master } \\
\text { Teacher STEM serta } \\
\text { mengimplemtasikan di SMP } \\
\text { Kota Bandung. Namun di } \\
\text { tengah Pandemi sekarang } \\
\text { tidak dapat beejalan dengan } \\
\text { baik }\end{array}$ \\
\hline
\end{tabular}




\begin{tabular}{|c|c|c|c|c|c|c|c|c|c|c|c|c|c|c|c|c|c|}
\hline $\begin{array}{c}\text { SMAN 1 } \\
\text { CIAWIGEBANG }\end{array}$ & 2 & 1 & 2 & 2 & 3 & 3 & 3 & 3 & 3 & 4 & 4 & 3 & 4 & 2 & 3 & 3 & $\begin{array}{l}\text { Pemerintah sudah cukup baik } \\
\text { dalam mengintegrasikan } \\
\text { pendidikan STEM terhadap } \\
\text { Kurikulum Nasional, tetapi } \\
\text { pemerintah harus } \\
\text { mensosialisasikan kepada } \\
\text { guru-guru terkait STEM } \\
\text { karena tidak semua tahu } \\
\text { tentang STEM }\end{array}$ \\
\hline SMAN 1 Ciawigebang & 3 & 4 & 2 & 2 & 2 & 2 & 2 & 1 & 3 & 2 & 3 & 3 & 3 & 2 & 3 & 3 & $\begin{array}{l}\text { Sejauh ini pemerintah baru } \\
\text { memberikan perkenalan } \\
\text { STEM bagi guru } 2 \text { tertentu, } \\
\text { sehingga secara keseluruhan } \\
\text { semua guru STEM belum } \\
\text { sepenuhnya mengetahui dan } \\
\text { menerapkan STEM. Selain } \\
\text { itu, di beberapa sekolah } \\
\text { banyak kendala saat guru } \\
\text { akan menerapkan STEM } \\
\text { kepada siswa, baik dari segi } \\
\text { sarana maupun kemampuan } \\
\text { kognitif siswa sendiri. }\end{array}$ \\
\hline $\begin{array}{c}\text { SMPN } 4 \text { Tarogong } \\
\text { Kidul }\end{array}$ & 3 & 1 & 1 & 4 & 2 & 2 & 3 & 2 & 3 & 3 & 3 & 3 & 3 & 3 & 3 & 4 & $\begin{array}{l}\text { STEM merupakan hal yang } \\
\text { baru bagi sebagian guru. Hal } \\
\text { itu menandakan pemerintah } \\
\text { belum sepenuhnya/masih } \\
\text { kurang mengintegrasikan } \\
\text { pendidikan STEM terhadap } \\
\text { kurikulum nasional }\end{array}$ \\
\hline MTs NU Putra 1 & 3 & 1 & 1 & 2 & 2 & 2 & 2 & 2 & 2 & 3 & 3 & 3 & 3 & 2 & 3 & 3 & $\begin{array}{l}\text { Pemerintah harus } \\
\text { mengupayakan penerapan } \\
\text { STEM dalam pembelajaran } \\
\text { Sains agar KBM bisa lebih } \\
\text { optimal dan efektif. Selain itu }\end{array}$ \\
\hline
\end{tabular}




\begin{tabular}{|c|c|c|c|c|c|c|c|c|c|c|c|c|c|c|c|c|c|}
\hline & & & & & & & & & & & & & & & & & $\begin{array}{l}\text { perlu sosialisasi secara } \\
\text { menyeluruh ke tiap sekolah } \\
\text { agar harapannya tidak hanya } \\
\text { sekolah di kota saja yang bisa } \\
\text { menerapkan namun semua } \\
\text { sekolah bisa. }\end{array}$ \\
\hline $\begin{array}{c}\text { SMP Bina Sarana } \\
\text { Cendekia }\end{array}$ & 3 & 4 & 1 & 1 & 2 & 2 & 3 & 2 & 3 & 2 & 3 & 3 & 3 & 2 & 3 & 4 & $\begin{array}{l}\text { Menurut saya pembelajaran } \\
\text { stem belum bisa dilaksanakan } \\
\text { secara efektif dan } \\
\text { menyekuruh di Indonesia. } \\
\text { Karena keterbatasan fasilitas } \\
\text { dan sumber daya yang belum } \\
\text { memadai di masing masing } \\
\text { sekolah }\end{array}$ \\
\hline MAN 2 Tasikmalaya & 2 & 1 & 2 & 2 & 3 & 3 & 3 & 2 & 3 & 3 & 3 & 3 & 4 & 3 & 3 & 3 & $\begin{array}{l}\text { Khusus pada mata pelajaran } \\
\text { yang saya ampu, kompetensi } \\
\text { pada kurikulum Nasional } \\
\text { menuntut siswa memiliki } \\
\text { keterampilan proses sains }\end{array}$ \\
\hline Man 2 Tasikmalaya & 2 & 4 & 2 & 1 & 3 & 4 & 3 & 4 & 4 & 4 & 3 & 3 & 4 & 3 & 3 & 3 & $\begin{array}{l}\text { Pendidikan STEM menurut } \\
\text { saya itu bagus, karena lebih } \\
\text { ke mengembangkan } \\
\text { kreativitas dalam pemecahan } \\
\text { masalah dikehidupan sehari- } \\
\text { hari. Sehingga baik juga } \\
\text { mengintegrasikan pendidikan } \\
\text { STEM kedalam kurikulum } \\
\text { nasional }\end{array}$ \\
\hline MAN 2 Tasikmalaya & 4 & 1 & 2 & 2 & 2 & 2 & 2 & 2 & 2 & 2 & 3 & 3 & 3 & 1 & 1 & 2 & $\begin{array}{l}\text { Belum sepenuhnya dijalankan } \\
\text { karena pada pelajaran kimia } \\
\text { sendiri, baru hanya sebagian } \\
\text { kecil materi yang bisa } \\
\text { diterapkan dalam } \\
\text { pembelajaran stem }\end{array}$ \\
\hline
\end{tabular}




\begin{tabular}{|c|c|c|c|c|c|c|c|c|c|c|c|c|c|c|c|c|c|}
\hline MAN 2 Tasikmalya & 3 & 4 & 2 & 4 & 3 & 3 & 3 & 3 & 3 & 3 & 3 & 3 & 3 & 3 & 3 & 3 & Masih belum sepenuhnya \\
\hline MAN 2 Tasikmalaya & 3 & 4 & 2 & 1 & 2 & 3 & 3 & 1 & 2 & 3 & 3 & 3 & 3 & 3 & 2 & 2 & $\begin{array}{l}\text { Saya fikir Yang tertuang } \\
\text { dalam KI dan KD pada } \\
\text { kurikulum nasional sudah } \\
\text { mencerminkan } \\
\text { pengintegrasian pendidikan } \\
\text { STEM hanya saja } \\
\text { implementasinya masih } \\
\text { kurang }\end{array}$ \\
\hline $\begin{array}{l}\text { SMA ISLAM AL } \\
\text { AZHAR } 17 \text { GALUH } \\
\text { MAS KARAWANG }\end{array}$ & 4 & 1 & 2 & 2 & 3 & 2 & 3 & 2 & 2 & 2 & 3 & 3 & 3 & 2 & 3 & 3 & $\begin{array}{l}\text { Pandangan saya tentang } \\
\text { pemerintas yang } \\
\text { mengintegrasikan pendidikan } \\
\text { stem pada kurikulum kurang } \\
\text { maksimal dan merata. Karena } \\
\text { hanya baru di beberapa } \\
\text { sekolah dan kurnagnya } \\
\text { sosialisasi }\end{array}$ \\
\hline $\begin{array}{c}\text { MAN } 2 \\
\text { TASIKMALAYA }\end{array}$ & 2 & 1 & 2 & 4 & 3 & 3 & 3 & 3 & 3 & 3 & 3 & 3 & 3 & 2 & 3 & 3 & Tertuang dalam KI dan KD \\
\hline SMA Negeri 15 Garut & 2 & 1 & 2 & 4 & 3 & 2 & 3 & 2 & 2 & 2 & 3 & 3 & 4 & 2 & 3 & 3 & $\begin{array}{l}\text { The government should be } \\
\text { fulfill the things that students } \\
\text { need like: internet, laboratory, } \\
\text { science properties etc }\end{array}$ \\
\hline SMAN 8 Garut & 2 & 4 & 2 & 4 & 3 & 3 & 2 & 2 & 3 & 3 & 4 & 3 & 3 & 1 & 3 & 3 & kurang meratanya pelatihan \\
\hline MTs Sunan Cipancar & 3 & 1 & 1 & 2 & 2 & 2 & 2 & 2 & 2 & 2 & 3 & 3 & 3 & 2 & 2 & 2 & $\begin{array}{l}\text { Menurut saya, pemerintah } \\
\text { belum begitu menekankan } \\
\text { tentang penerapan } \\
\text { pengintegrasian pendidikan } \\
\text { STEM terhadap Kurikulum } \\
\text { Nasional, sehingga dalam } \\
\text { pelaksanaannya tidak semua } \\
\text { guru mampu menerapkan dan } \\
\text { mengembangkan pendidikan } \\
\text { STEM. }\end{array}$ \\
\hline
\end{tabular}




\begin{tabular}{|c|c|c|c|c|c|c|c|c|c|c|c|c|c|c|c|c|c|}
\hline $\begin{array}{c}\text { MAN } 3 \\
\text { MAJALENGKA }\end{array}$ & 3 & 1 & 2 & 4 & 2 & 2 & 2 & 3 & 3 & 3 & 4 & 4 & 4 & 2 & 3 & 2 & $\begin{array}{l}\text { Integrasi Pembelajaran STEM } \\
\text { dengan Kurikulum Nasional } \\
\text { telah dilakukan terus dan } \\
\text { terus ditingkatkan, di } \\
\text { antaranya melalui pelatihan } \\
\text { guru dan penyediaan modul } \\
\text { Pembelajaran STEM }\end{array}$ \\
\hline SMP Darul Hikam & 4 & 1 & 1 & 2 & 1 & 1 & 2 & 2 & 2 & 2 & 3 & 4 & 3 & 2 & 2 & 1 & $\begin{array}{l}\text { Masih kurang dalam } \\
\text { pembiasaan terhadap guru- } \\
\text { guru, serta evaluasi atau } \\
\text { penilaian yg tidak sinkron } \\
\text { antara stem dengan tuntutan } \\
\text { nilai akhir. }\end{array}$ \\
\hline $\begin{array}{l}\text { Sekolah Kuntum } \\
\text { Cemerlang }\end{array}$ & 2 & 4 & 2 & 2 & 2 & 3 & 3 & 4 & 3 & 4 & 3 & 3 & 4 & 4 & 4 & 3 & $\begin{array}{l}\text { Kurikulum masih berfokus } \\
\text { terhadap nilai capian siswa, } \\
\text { tidak lebih dari proses yang } \\
\text { dicapai oleh siswa, karena } \\
\text { saya sebagai guru sangat } \\
\text { paham keberagaman } \\
\text { kemampuan anak. Sehingga } \\
\text { minat dan bakat anak tidak } \\
\text { dapat terfasilitasu dengan } \\
\text { baik oleh kurikulum }\end{array}$ \\
\hline Smp\&smk bakti ilham & 2 & 1 & 1 & 1 & 1 & 2 & 3 & 3 & 2 & 2 & 1 & 1 & 3 & 1 & 3 & 2 & $\begin{array}{l}\text { Sediakan buku dan pelatihan, } \\
\text { kalau lebih serius bikin } \\
\text { peraturannya, tidak semua } \\
\text { guru dan sekolah bisa } \\
\text { memakai stem, terlebih } \\
\text { kondisi fasilitas yang kurang } \\
\text { memadai }\end{array}$ \\
\hline Sman 9 Bandung & 3 & 1 & 2 & 1 & 2 & 1 & 2 & 2 & 1 & 1 & 4 & 3 & 4 & 3 & 2 & 2 & $\begin{array}{l}\text { Pemerintah telah } \\
\text { mengintegrasikan pendidikan } \\
\text { STEM pada kurikulum } \\
\text { nasional, namun pada }\end{array}$ \\
\hline
\end{tabular}




\begin{tabular}{|c|c|c|c|c|c|c|c|c|c|c|c|c|c|c|c|c|c|}
\hline & & & & & & & & & & & & & & & & & $\begin{array}{l}\text { umumnya guru masih belum } \\
\text { terlalu paham cara } \\
\text { pelaksanaannya sehingga di } \\
\text { sekolag guru lebuh sering } \\
\text { menyampaikan materi } \\
\text { berbasis konsep-konsep kimia } \\
\text { saja }\end{array}$ \\
\hline $\begin{array}{l}\text { MA Multiteknik Asih } \\
\text { Putera Cimahi }\end{array}$ & 1 & 1 & 2 & 2 & 2 & 2 & 3 & 3 & 3 & 3 & 3 & 3 & 3 & 2 & 2 & 3 & $\begin{array}{l}\text { Materi terlalu banyak, } \\
\text { terkadang terasa berat untuk } \\
\text { beberapa siswa. }\end{array}$ \\
\hline Mts Asih Putera & 2 & 4 & 1 & 1 & 3 & 3 & 3 & 3 & 3 & 3 & 3 & 3 & 3 & 3 & 4 & 4 & Cukup baik \\
\hline Smp darul hikan & 3 & 1 & 1 & 2 & 2 & 3 & 3 & 2 & 2 & 3 & 4 & 4 & 4 & 4 & 3 & 3 & $\begin{array}{l}\text { Pemerintah kurang } \\
\text { menyiapkan secara merata } \\
\text { sdm yang siap untuk } \\
\text { mengajarkan full stem kepada } \\
\text { siswa di sekolah, kebanyakan } \\
\text { merasa kebingungan dalam } \\
\text { merancang stem, sebagian } \\
\text { besar belum bisa } \\
\text { membedakan mana stem, } \\
\text { mana praktikum biasa mana } \\
\text { prakarya }\end{array}$ \\
\hline MTs Al-Rohmah & 2 & 4 & 1 & 4 & 2 & 3 & 3 & 2 & 3 & 3 & 3 & 3 & 3 & 2 & 3 & 4 & $\begin{array}{l}\text { Hal ini bisa dilihat dari } \\
\text { pendekatannya sendiri yakni } \\
\text { pendekatan saintifik. }\end{array}$ \\
\hline $\begin{array}{c}\text { SMPN } 3 \text { Cibadak } \\
\text { Sukabumi Jawa Barat }\end{array}$ & 3 & 1 & 1 & 4 & 2 & 2 & 2 & 3 & 3 & 3 & 3 & 3 & 3 & 2 & 3 & 3 & $\begin{array}{l}\text { Untuk tingkat SMP } \\
\text { pendekatan STEM belum } \\
\text { dapat diaplikasikan dlm } \\
\text { proses pembelajaran secara } \\
\text { maksimal, lebih banyak } \\
\text { diterapkan dalam materi } \\
\text { fisika, mengaplikasikan } \\
\text { STEM secara utuh baru dapat } \\
\text { melaksanakan di akhir }\end{array}$ \\
\hline
\end{tabular}




\begin{tabular}{|c|c|c|c|c|c|c|c|c|c|c|c|c|c|c|c|c|c|}
\hline & & & & & & & & & & & & & & & & & $\begin{array}{l}\text { semester sebagai penilaian } \\
\text { project fisika. Pendidikan } \\
\text { STEM belum } \\
\text { diimplementasikan di dlm } \\
\text { kurikulum tingkat SMP } \\
\text { secara maksimal, guru juga } \\
\text { mengkondisikan dengan } \\
\text { sarana prasarana, sumber } \\
\text { daya dan intake siswa. }\end{array}$ \\
\hline SMPN 1 cicurug & 2 & 1 & 1 & 4 & 3 & 4 & 4 & 4 & 4 & 3 & 4 & 3 & 4 & 3 & 4 & 4 & $\begin{array}{l}\text { Dengan menerancang masuk } \\
\text { ke dalam silabus ke program } \\
\text { pembelajaran }\end{array}$ \\
\hline SMAN 15 GARUT & 2 & 1 & 2 & 4 & 3 & 3 & 3 & 3 & 3 & 3 & 3 & 3 & 3 & 3 & 4 & 3 & $\begin{array}{l}\text { Sosialisasi tentang } \\
\text { pembelajaran STEM harus } \\
\text { lebih ditingkatkan dan } \\
\text { didosialusasikan secara } \\
\text { merata ke seluruh guru sains } \\
\text { dengan mengadakan pelatihan } \\
\text { di tempat yang terjangkau dan } \\
\text { tidak terlalu menyita waktu. }\end{array}$ \\
\hline UPI & 2 & 1 & 2 & 2 & 2 & 2 & 3 & 2 & 3 & 1 & 3 & 3 & 3 & 1 & 2 & 1 & $\begin{array}{l}\text { dalam tahap apersepsi dan } \\
\text { motovasi di rancangan } \\
\text { pembelajaran sudah mulai } \\
\text { menerapkan konsep STEM } \\
\text { dimana ada bagian ini siswa } \\
\text { dijelaskan ttg salah satu } \\
\text { manfaat belajar mengenai } \\
\text { materi yg sedang dipelajari } \\
\text { jika diterapkana atau ada di } \\
\text { dunia nyata seperti apa. tapi } \\
\text { kadang tuntutan ki kd yg } \\
\text { tetlalu banyak membuat guru } \\
\text { kesulitan berkreasi karena }\end{array}$ \\
\hline
\end{tabular}




\begin{tabular}{|c|c|c|c|c|c|c|c|c|c|c|c|c|c|c|c|c|c|}
\hline & & & & & & & & & & & & & & & & & $\begin{array}{l}\text { keterbatasan waktu mengejar } \\
\text { target ki kd. }\end{array}$ \\
\hline $\begin{array}{l}\text { SMK CILEDUG AL } \\
\text { MUSADDADIYAH } \\
\text { GARUT }\end{array}$ & 2 & 3 & 2 & 4 & 3 & 3 & 2 & 2 & 2 & 2 & 3 & 3 & 3 & 3 & 3 & 3 & $\begin{array}{l}\text { reformasi kurikulum } \\
\text { persekolahan sudah diarahkan } \\
\text { untuk membekali peserta } \\
\text { didik pada karakteristik } \\
\text { warga negara abad 21, namun } \\
\text { khususnya kurikulum untuk } \\
\text { mata pelajaran sains belum } \\
\text { secara eksplisit } \\
\text { mengintegrasikan STEM. } \\
\text { Walaupun demikian, } \\
\text { kurikulum nasional } \\
\text { (Kurikulum 2013) memiliki } \\
\text { semangat yang mendukung } \\
\text { para guru dan sekolah untuk } \\
\text { mengeksplorasi dan } \\
\text { menerapkan STEM sebagai } \\
\text { pendekatan pembelajaran } \\
\text { melalui penggunaan model } \\
\text { pembelajaran berbasis proyek } \\
\text { (PJBL), atau model } \\
\text { pembelajaran lainnya, seperti } \\
\text { siklus belajar 5E dan LOI } \\
\text { (Level of Inquiry) }\end{array}$ \\
\hline $\begin{array}{l}\text { SMA Daarut Tauhiid } \\
\text { Boarding School }\end{array}$ & 2 & 1 & 2 & 2 & 3 & 3 & 4 & 3 & 3 & 2 & 4 & 3 & 3 & 2 & 3 & 3 & $\begin{array}{l}\text { Pemerintah sangat } \\
\text { mendukung pendidikan } \\
\text { STEM, hanya saja belum } \\
\text { maksimal karena belum } \\
\text { meratanya ketersediaan Alat } \\
\text { Praktikum untuk mendukung } \\
\text { pendidikan STEM di } \\
\text { beberapa sekolah }\end{array}$ \\
\hline
\end{tabular}




\begin{tabular}{|c|c|c|c|c|c|c|c|c|c|c|c|c|c|c|c|c|c|}
\hline universitas kuningan & 3 & 1 & 1 & 1 & 3 & 3 & 2 & 2 & 2 & 3 & 4 & 3 & 4 & 1 & 2 & 2 & $\begin{array}{l}\text { dengan menggunakan } \\
\text { pembelajaran yang } \\
\text { kontekstual }\end{array}$ \\
\hline SMAN 25 Garut & 3 & 1 & 2 & 2 & 2 & 2 & 3 & 2 & 3 & 3 & 4 & 4 & 4 & 4 & 3 & 4 & $\begin{array}{l}\text { Pendidikan STEM dalam } \\
\text { kurikulum nasional telah } \\
\text { disusun oleh pemerintah } \\
\text { dengan cukup baik, namun } \\
\text { implementasi di lapangan } \\
\text { oleh guru masih sanagat } \\
\text { kurang. Masih banyak guru } \\
\text { yang belum memahami } \\
\text { pembelajaran stem. } \\
\text { Seharusnya pemerintah } \\
\text { mengintegrasikan pendidikan } \\
\text { stem dalam kurikulum } \\
\text { nasional ini dibarengi dengan } \\
\text { pelatihan bagi guru-guru dan } \\
\text { pemantauan yang rutin di } \\
\text { lapangan. }\end{array}$ \\
\hline SMAN 2 garut & 1 & 1 & 2 & 2 & 2 & 3 & 3 & 3 & 3 & 4 & 3 & 3 & 3 & 4 & 3 & 3 & $\begin{array}{l}\text { Sebenarnya kurikulum } \\
\text { nasional sudah menyediakan } \\
\text { berbagai metode } \\
\text { pembelajaran yang sesuai } \\
\text { dengan pendidikan stem, } \\
\text { namun tetap kalau dilapangan } \\
\text { ada faktor eksternal yang } \\
\text { mempengaruhi proses atau } \\
\text { bahkan keberhasilan } \\
\text { pelaksanaannya. Seperti } \\
\text { kesiapan siswa daerah yang } \\
\text { masih minim dan masih asing } \\
\text { dengan beberapa metode } \\
\text { pembelajaran yang } \\
\text { disarankan dalam penerapan }\end{array}$ \\
\hline
\end{tabular}




\begin{tabular}{|c|c|c|c|c|c|c|c|c|c|c|c|c|c|c|c|c|c|}
\hline & & & & & & & & & & & & & & & & & $\begin{array}{l}\text { kurikulum nasional yang } \\
\text { berintegrasi dengan } \\
\text { pendidikan stem. }\end{array}$ \\
\hline SMAN 2 GARUT & 3 & 1 & 2 & 1 & 2 & 2 & 3 & 2 & 2 & 4 & 1 & 3 & 3 & 2 & 3 & 2 & $\begin{array}{l}\text { Menurut saya,kurikulum } \\
\text { persekolahan sudah diarahkan } \\
\text { untuk membekali peserta } \\
\text { didik pada karakteristik } \\
\text { modern, namun khususnya } \\
\text { kurikulum untuk mata } \\
\text { pelajaran sains belum secara } \\
\text { eksplisit mengintegrasikan } \\
\text { STEM. }\end{array}$ \\
\hline SMA Negeri 2 Garut & 2 & 2 & 2 & 2 & 3 & 3 & 3 & 3 & 3 & 3 & 4 & 3 & 3 & 3 & 3 & 3 & $\begin{array}{l}\text { Kurikulum yang diterapkan } \\
\text { saat ini menonjolkan ke arah } \\
\text { berpikir kritis, berpikir } \\
\text { kreatif, inovatif, kemampuan } \\
\text { menyelesaikan masalah, } \\
\text { komputerisasi, kemandirian } \\
\text { dalam belajar serta berkarir, } \\
\text { penguatan pendidikan } \\
\text { karakter (PPK) dan literasi. } \\
\text { Sehingga kurikulum yang } \\
\text { diimplementasikan saat ini } \\
\text { banyak aspek yang } \\
\text { memungkinkan implementasi } \\
\text { STEM masuk ke dalamnya. }\end{array}$ \\
\hline SMAN 3 BANDUNG & 2 & 4 & 2 & 3 & 2 & 2 & 2 & 3 & 2 & 3 & 3 & 3 & 3 & 2 & 2 & 3 & $\begin{array}{l}\text { melalui program wajib belajar } \\
\text { di sekolah, disini pemerintah } \\
\text { pun menyelenggarakan } \\
\text { pelatihan bagi guru mengenai } \\
\text { cara mengimplementasikan } \\
\text { STEM dalam KBM disekolah }\end{array}$ \\
\hline Sman 3 Bandung & 1 & 1 & 2 & 4 & 4 & 3 & 4 & 3 & 3 & 3 & 4 & 4 & 4 & 3 & 4 & 4 & $\begin{array}{l}\text { Penilaian KD 4, untuk } \\
\text { ketrampilan }\end{array}$ \\
\hline
\end{tabular}




\begin{tabular}{|c|c|c|c|c|c|c|c|c|c|c|c|c|c|c|c|c|c|}
\hline SMAN 1 BANDUNG & 2 & 4 & 2 & 1 & 2 & 3 & 2 & 3 & 3 & 2 & 3 & 3 & 3 & 2 & 3 & 2 & Masih kurang \\
\hline $\begin{array}{c}\text { SMP NEGERI } 1 \\
\text { GARUT }\end{array}$ & 2 & 4 & 1 & 4 & 4 & 4 & 4 & 4 & 4 & 4 & 4 & 4 & 4 & 4 & 4 & 4 & $\begin{array}{l}\text { Sebagaimana dinyatakan } \\
\text { dalam Kerangka Dasar dan } \\
\text { Struktur Kurikulum } 2013 \\
\text { jenjang Sekolah Menengah } \\
\text { Pertama/Madrasah } \\
\text { Tsanawiyah (Kemdikbud, } \\
\text { 2013), bahwa kurikulum } \\
\text { 2013 bertujuan untuk } \\
\text { mempersiapkan manusia } \\
\text { Indonesia agar memiliki } \\
\text { kemampuan hidup sebagai } \\
\text { pribadi yang beriman, } \\
\text { produktif, kreatif, inovatif, } \\
\text { dan efektif serta mampu } \\
\text { berkontribusi pada kehidupan } \\
\text { bermasyarakat, berbangsa, } \\
\text { bernegara, dan peradaban } \\
\text { dunia. Dinyatakan pula dalam } \\
\text { dokumen tersebut bahwa } \\
\text { salah satu pola pikir baru } \\
\text { yang digunakan sebagai dasar } \\
\text { pengembangan Kurikulum } \\
\text { 2013 adalah pola } \\
\text { pembelajaran ilmu } \\
\text { pengetahuan tunggal } \\
\text { (monodicipline) menjadi } \\
\text { pembelajaran ilmu } \\
\text { pengetahuan jamak } \\
\text { (multidicipline). Rumusan } \\
\text { tujuan dan pola pikir dalam } \\
\text { pengembangan Kurikulum } \\
\text { 2013 yang dikemukakan } \\
\text { tersebut mengisyaratkan }\end{array}$ \\
\hline
\end{tabular}




\begin{tabular}{|c|c|c|c|c|c|c|c|c|c|c|c|c|c|c|c|c|c|}
\hline & & & & & & & & & & & & & & & & & $\begin{array}{l}\text { bahwa Kurikulum } 2013 \\
\text { memberikan ruang bagi } \\
\text { pengembangan dan } \\
\text { implementasi pendidikan } \\
\text { STEM dalam konteks } \\
\text { implementasi Kurikulum } \\
\text { 2013, yang mengutamakan S, } \\
\mathrm{T} \text {, E, dan M secara multi- dan } \\
\text { trans-disiplin serta } \\
\text { pengembangan pemikiran } \\
\text { kritis, kreativitas, inovasi, dan } \\
\text { kemampuan memecahkan } \\
\text { masalah }\end{array}$ \\
\hline SMPN 6 Bandung & 3 & 1 & 1 & 2 & 2 & 2 & 3 & 2 & 3 & 3 & 3 & 3 & 3 & 2 & 3 & 4 & $\begin{array}{l}\text { Menurut saya, pendidikan di } \\
\text { Indonesia saat ini belum } \\
\text { sepenuhnya menerapkan } \\
\text { pendidikan stem dalam } \\
\text { kurikulum nasional, } \\
\text { dikarenakan sdm belum } \\
\text { paham akan stem, dan masih } \\
\text { banyak guru yg mengajar } \\
\text { hanya untuk menggugurkan } \\
\text { kewajibannya saja. Dan jg } \\
\text { kondisi pandemi saat ini yg } \\
\text { mengharuskan guru tetap } \\
\text { berinovasi dan beradaptasi } \\
\text { dalam pembelajaran jarak } \\
\text { jauh }\end{array}$ \\
\hline MA Alfurqon & 3 & 1 & 2 & 2 & 2 & 2 & 3 & 2 & 3 & 3 & 2 & 3 & 3 & 2 & 3 & 3 & $\begin{array}{l}\text { Harus lebih memberi fasilitas } \\
\text { yang mendukung untuk } \\
\text { meningkatkan pembelajaran }\end{array}$ \\
\hline $\begin{array}{l}\text { SMP al irsyad satya } \\
\text { islamic school }\end{array}$ & 4 & 1 & 1 & 1 & 1 & 1 & 1 & 1 & 1 & 1 & 3 & 3 & 3 & 1 & 3 & 3 & $\begin{array}{l}\text { Saat ini pemerintah sudah } \\
\text { mengimplementasikan stem } \\
\text { pada setiap pembelajaran }\end{array}$ \\
\hline
\end{tabular}




\begin{tabular}{|c|c|c|c|c|c|c|c|c|c|c|c|c|c|c|c|c|c|}
\hline & & & & & & & & & & & & & & & & & $\begin{array}{l}\text { sciene, salah satunya melalui } \\
\text { projek atau praktikum. } \\
\text { Namun untuk pelaksanaan } \\
\text { nya, banyak murid yang } \\
\text { belum paham atau tidak sadar } \\
\text { bahwa pembelajaran yang } \\
\text { diterima termasuk } \\
\text { pembelajaran stem }\end{array}$ \\
\hline SMAN 1 Ciemas & 3 & 1 & 2 & 2 & 2 & 2 & 3 & 2 & 3 & 3 & 3 & 3 & 3 & 2 & 3 & 2 & $\begin{array}{l}\text { Upaya Pemerintah dalam } \\
\text { mengintegrasika pendidikan } \\
\text { STEM terhadap Kurikulum } \\
\text { Nasional di Indonesia masih } \\
\text { sangat kurang, masih banyak } \\
\text { sekolah yg dengan banyaknya } \\
\text { jumlah siswa yg memilih IPA } \\
\text { sebagai jurusannya tetapi } \\
\text { pada kenyataannya siswa } \\
\text { tidak dengan baik mengerti } \\
\text { dan memahami konsep dasar } \\
\text { yg ada di IPA, padahal } \\
\text { dengan adanya STEM siswa } \\
\text { diharapkan dapat memahami } \\
\text { dengan baik konsep yg ada. } \\
\text { Pemerintah perlu melakukan } \\
\text { pemerataan terhadap sekolah- } \\
\text { sekolah yg berada di daerah } \\
\text { yg jauh dari jangkauan agar } \\
\text { terfasilitasi dengan baik dan } \\
\text { siswa dapat memahami } \\
\text { konsep sesuai dengan } \\
\text { kurikulum yg ada dengan } \\
\text { menggunaka STEM }\end{array}$ \\
\hline $\begin{array}{c}\text { SMK N } 1 \text { Cisarua } \\
\text { Bandung Barat }\end{array}$ & 1 & 1 & 2 & 1 & 4 & 3 & 4 & 4 & 4 & 4 & 4 & 4 & 4 & 1 & 4 & 4 & $\begin{array}{l}\text { kurikulum untuk mata } \\
\text { pelajaran sains belum secara }\end{array}$ \\
\hline
\end{tabular}




\begin{tabular}{|c|c|c|c|c|c|c|c|c|c|c|c|c|c|c|c|c|c|}
\hline & & & & & & & & & & & & & & & & & $\begin{array}{l}\text { eksplisit mengintegrasikan } \\
\text { STEM. Walaupun demikian, } \\
\text { kurikulum nasional } \\
\text { (Kurikulum 2013) memiliki } \\
\text { semangat yang mendukung } \\
\text { para guru dan sekolah untuk } \\
\text { mengeksplorasi dan } \\
\text { menerapkan STEM sebagai } \\
\text { pendekatan pembelajaran } \\
\text { melalui penggunaan model } \\
\text { pembelajaran yang telah } \\
\text { disarankan seperti } \\
\text { pembelajaran berbasis proyek } \\
\text { (PJBL), model 5E dan LOI } \\
\text { (Level of Inquiry). }\end{array}$ \\
\hline SMPN 1 Cilawu Garut & 3 & 1 & 1 & 3 & 2 & 3 & 3 & 2 & 2 & 2 & 3 & 3 & 3 & 3 & 3 & 3 & $\begin{array}{l}\text { Di daerah masih belum } \\
\text { banyak campur tangan } \\
\text { pemerintah dinas setempat } \\
\text { untuk mensosialisasikan } \\
\text { pembelajaran berbasis STEM }\end{array}$ \\
\hline SMPN 1 CONGGEANG & 2 & 1 & 1 & 4 & 3 & 2 & 3 & 2 & 2 & 2 & 3 & 3 & 3 & 2 & 3 & 3 & $\begin{array}{l}\text { Masih belum cukup, banyak } \\
\text { guru kesulitan dalam } \\
\text { implementasi di lapangan }\end{array}$ \\
\hline $\begin{array}{l}\text { SMPIT UNGGULAN } \\
\text { ALBAROKAH } \\
\text { MADANI }\end{array}$ & 2 & 1 & 1 & 3 & 3 & 3 & 3 & 3 & 3 & 2 & 3 & 3 & 3 & 3 & 3 & 3 & $\begin{array}{l}\text { Sejauh ini pemerintah sudah } \\
\text { mengupayakan peningkatan } \\
\text { kualitas pendidikan Indonesia } \\
\text { salah satunya dengan } \\
\text { rancangan kurikulum nasional } \\
\text { yang didalamnya terintegrasi } \\
\text { pendidikan berbasis STEM } \\
\text { demi menunjang kualitas } \\
\text { pendidikan Indonesia di masa } \\
\text { yang akan datang }\end{array}$ \\
\hline
\end{tabular}




\begin{tabular}{|c|c|c|c|c|c|c|c|c|c|c|c|c|c|c|c|c|c|}
\hline $\begin{array}{l}\text { SMA Negeri } 1 \\
\text { Kabandungan }\end{array}$ & 2 & 1 & 2 & 4 & 2 & 1 & 3 & 3 & 3 & 2 & 4 & 4 & 4 & 3 & 3 & 3 & $\begin{array}{l}\text { Pemerintah belum maksimal } \\
\text { menerapkan pendidikan } \\
\text { STEM untuk diintegrasikan } \\
\text { dengan kurikulum nasional }\end{array}$ \\
\hline SMPN 1 CONGGEANG & 2 & 1 & 1 & 4 & 3 & 3 & 2 & 3 & 3 & 2 & 3 & 3 & 3 & 2 & 2 & 2 & $\begin{array}{l}\text { Secara umum pemerintah } \\
\text { sudah mengintegrasikan Stem } \\
\text { dalam kurikulum, akan tetapi } \\
\text { bnyak guru yang ksulitan } \\
\text { menerapknya dalam } \\
\text { pembelajaran }\end{array}$ \\
\hline Sekolah Cikal Serpong & 3 & 1 & 1 & 1 & 3 & 3 & 3 & 3 & 3 & 3 & 2 & 3 & 2 & 4 & 4 & 3 & $\begin{array}{l}\text { In my opinion the National } \\
\text { Curriculum some of them are } \\
\text { quite great if we integrates to } \\
\text { STEM learning, the KI and } \\
\text { KD state that the students } \\
\text { need to be able creates } \\
\text { something based on the topic, } \\
\text { but to be able to conduct } \\
\text { those learning model or truly } \\
\text { applying the STEM learning } \\
\text { is not enough if the } \\
\text { government only put it on the } \\
\text { curriculum, it need further } \\
\text { training for the teacher such } \\
\text { as how to conduct proper } \\
\text { assessment to use STEM } \\
\text { learning, how to design the } \\
\text { learning process, how to do } \\
\text { reflection with the students. } \\
\text { Personally I teach in private } \\
\text { school that support project } \\
\text { based learning for the term } \\
\text { exam or semester exam, and } \\
\text { we use combine curriculum }\end{array}$ \\
\hline
\end{tabular}




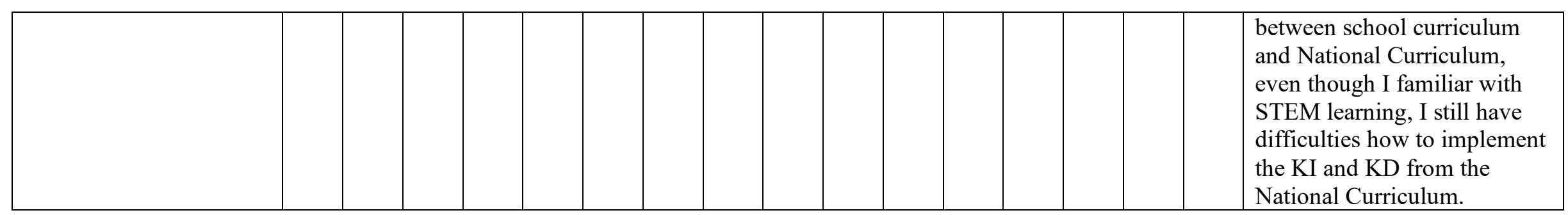

The in-depth interview

\section{Science Teacher (Physics)}

1. STEM education is for natural sciences is suitable for synergizing natural knowledge and mathematics with technology that can be utilized in daily life.

2. This STEM education affects STEM teaching in the classroom. The effect is that, when we apply STEM, teachers have to dig again on how to master the basic concepts of natural knowledge to apply to technology, and teachers become technologically literate. In terms of children, it spurs the child's motivation to learn when they want to use it in technology. They have to master basic concepts.

3. I quite often discuss with other teachers, especially science teachers. When there is a new technology, we discuss applying the technology in learning following the curriculum. We met a month four times.

4. While teaching, I explore the child's knowledge of the latest technology. Students are asked to create a project. For example, they are developing simple technologies related to the material taught. 
5. The evaluation form is grouped. I assess the level of cooperation, the process of designing until the project, whether the simple tool works or not, and the child's understanding of the related material. The knowledge assessment uses its portfolio and project results.

6. In the project, students are not once successful, so we discuss and find a standard solution. This activity looks successful when students do the project again, and there appears to be a change. So, it can be said that the project is successful.

7. Human resources (students) students should be more excited and motivated again. The facilities should also be adequate. Because the facilities are lacking, students only design and do not apply them in real-time. For the present circumstances, facilities and resources already exist. We're using simple tools, and we're using the tools around. The learning resources are beneficial, and now students are easier to access information on the internet.

Technology Teacher

1. In terms of understanding, STEM Education is multiple disciplines with scientific literacy, technology, engineering, and mathematics. In addition, STEM further enriches students' competencies in their STEM-based curriculum.

2. Its influence affects in terms of creativity, imagination, and competence of students in their learning process.

3. I haven't had too many discussions with other teachers in the same field. It's still socializing. I've had conversations with teachers in the same and different areas. For example, in creating a project, discussions with other teachers, such as mathematics and science, are required. But the meetings have not gone simultaneously. 
4. I created a lesson plan before starting the class. From the National Curriculum, there are already core and basic competencies. So, we have to apply it in its STEM-based lesson plan.

5. In terms of the form of implementation, do a project. First, students create a planning project for approximately two weeks. Before doing a planning project, students need to propose and discuss the project's title with the teacher concerned. And the creation of the project has been in the direction of the National Curriculum. Besides, I also provide an alternative title for the project adapted to the existing KI and KD. Discussions with other teachers are also related, such as science and math teachers.

6. Assessment there is formative, where I see the progress of students in doing the project. Assessments are carried out from the title proposal to project trials. And at the end, for students who successfully do the project is rewarded. In addition, it is also assessed the documentation of students in doing the project.

7. Feedback is given at all times from the start of the title proposal to the end because students need to be directed from the beginning to succeed in its project trials.

8. Human resources are crucial to STEM learning. Because students depend on their teacher, creativity can be created. That teaching source can be in any form, from the internet and forums. So, some forums and blogs are used to interact with students, and between students can also communicate.

Engineering Teacher 
1. Stem education is more logical. It's like teaching engineering with science materials. STEM is more complicated. One lesson but can include many lessons.

2. STEM education affects curriculum and learning in the classroom because learning has to be in sync. For example, the current curriculum, between mathematics, physics, and chemistry, is synonymous with my class's teaching.

3. I often share and synchronize some learning materials with the teacher at the previous level, such as the first-grade teacher. This is so that students can participate in learning in the second grade. It's more about learning about students' difficulties in learning. For example, students who are difficult to count, so teachers in first grade teach more about counting. Thus, students have a primary mindset before entering the second grade.

4. In learning planning, I noticed first how $\mathrm{KI}$ and $\mathrm{KD}$ and also the learning indicators. It also has to know how students are capable of. Thus, the indicators created do not need much for learning to be maximal. For example, in one learning material is made into three meetings because it adjusts to the child's condition. That first meeting was to build a child's mindset. The second meeting, given the problem and how the solution. The third and fourth meeting is practice.

5. STEM integration in learning, in defense of theory, further reviews and recalls science materials related to engineering. But, the implementation is more practical. Because in vocational schools, it's more of a practice.

6. The form of assessment used, for the theory of using an essay or multiple-choice, or troubleshooting, students are given conditions where there is a problem, and they need to find a solution. For practice, when students after trying and understanding and 
experiencing practice, in the end, there is a competency test by conducting examinations and treatment. Assessments are done from the way students use tools to cleanliness.

7. Feedback in the theory evaluation is done together to know what their shortcomings and mistakes are. Furthermore, it is given another test, such as enrichment. I see again whether or not it changes after feedback. Other things in practice, feedback is given directly during practice. It is essential because it affects the future.

8. The human resources (teachers) in my school were limited even though they were up to standard. But for the quality of their education has not met. Some teachers are out of sync with their educational background and what is being taught. In addition, the facilities and infrastructure are still lacking, such as learning media. So every teacher has to take turns using them. Even teachers are not given adequate teaching tools. The government already provides for learning resources, but some are in sync with the curriculum, but some are out of sync. So there is no synchronization between the teacher and the principal in the provision of student teaching resources. Thus, as a teacher, I am better off directing students to search for learning resources from the related internet. Therefore, students are more broadly insightful.

\section{Mathematics Teacher}

1. STEM education is like a pattern, and learning is tailored to the student's circumstances. STEM is seen from patterns, formulating, planning, making and evaluation, and the latter reflection. 
2. It's the same, such as problem-based learning, discovery learning, and STEM. It restored the readiness of the students and the preparation of the teachers. There's an apperception first. We look at the supporting material and discuss it first.

3. If applied can be important anyway because it is more orderly and composed learning.

4. I had a discussion, but after learning. It should be before the study is conducted discussions between subjects. It is challenging because communication between teachers' associations of every subject is difficult even though there are already facilities. The school should have organized more. There's a teacher's association, but the edges are a formality.

5. Implementing the curriculum, indirect learning is poorly executed due to the lack of ready teachers and students. For example, in the creation of HOTS (Higher Order Thinking Skills)'s problems get difficult. Besides, students are not prepared. It should be since elementary school students have been taught with the National Curriculum. So, it is restored with class conditions.

6. I didn't plan to apply STEM, but unwittingly I used this method when teaching. It has been implemented once, but even teachers are more active because students are not ready and lack previous understanding.

7. The assessments I did were more about questions, and portfolios were formed. Projects are given in groups, as it is difficult for math lessons to be given projects. The problem is in the form of an essay but for a reasoned multiple-choice exercise.

8. Every time after I give an assignment, I always ask if there are difficulties and discussed it together 
9. If for human resources, the students are good, which makes it easier for teachers to deliver materials. Conversely, if the student is lacking, the teacher should think hard about how they understand the lesson. For teaching resources, the school library provides appropriate books with the materials taught. 


\section{APPENDIX C: THE CORE COMPETENCIES IN THE NATIONAL CURRICULUM}

A. Core Competencies (KI) in Junior High School

\begin{tabular}{|c|c|c|}
\hline \multicolumn{3}{|c|}{ Core Competencies } \\
\hline Grade 7 & Grade 8 & Grade 9 \\
\hline $\begin{array}{l}\text { 1. Respect and live the } \\
\text { lesson of the religion the } \\
\text { students obey to }\end{array}$ & $\begin{array}{l}\text { 1. Respect and live the } \\
\text { lesson of the religion the } \\
\text { students obey to }\end{array}$ & $\begin{array}{l}\text { 1. Respect and live the } \\
\text { lesson of the religion the } \\
\text { students obey to }\end{array}$ \\
\hline $\begin{array}{l}\text { 2. Appreciating and living } \\
\text { honest, disciplined, } \\
\text { responsible, caring } \\
\text { (toleration, cooperate), } \\
\text { manners, confidence, in } \\
\text { interacting effectively } \\
\text { with the social and natural } \\
\text { environment within the } \\
\text { reach of association and } \\
\text { circumstances }\end{array}$ & $\begin{array}{l}\text { 2. Appreciating and living } \\
\text { honest, disciplined, } \\
\text { responsible, caring } \\
\text { (toleration, cooperate), } \\
\text { manners, confidence, in } \\
\text { interacting effectively } \\
\text { with the social and natural } \\
\text { environment within the } \\
\text { reach of association and } \\
\text { circumstances }\end{array}$ & $\begin{array}{l}\text { 2. Appreciating and living } \\
\text { honest, disciplined, } \\
\text { responsible, caring } \\
\text { (toleration, cooperate), } \\
\text { manners, confidence, in } \\
\text { interacting effectively } \\
\text { with the social and natural } \\
\text { environment within the } \\
\text { reach of association and } \\
\text { circumstances }\end{array}$ \\
\hline $\begin{array}{l}\text { 3. Understanding knowledge } \\
\text { (factual, conceptual, and } \\
\text { procedural) based on his } \\
\text { curiosity about science, } \\
\text { technology, art, culture, } \\
\text { related phenomena, and } \\
\text { real-world problem }\end{array}$ & $\begin{array}{l}\text { 3. Understanding and } \\
\text { applying knowledge } \\
\text { (factual, conceptual, and } \\
\text { procedural) based on his } \\
\text { curiosity about science, } \\
\text { technology, art, culture, } \\
\text { related phenomena, and } \\
\text { real-world problem }\end{array}$ & $\begin{array}{l}\text { 3. Understanding and } \\
\text { applying knowledge } \\
\text { (factual, conceptual, and } \\
\text { procedural) based on his } \\
\text { curiosity about science, } \\
\text { technology, art, culture, } \\
\text { related phenomena, and } \\
\text { real-world problem }\end{array}$ \\
\hline $\begin{array}{l}\text { 4. Trying, processing, and } \\
\text { presenting in concrete } \\
\text { realms (utilizing, } \\
\text { deconstructing, } \\
\text { constructing, modifying, } \\
\text { and creating) and abstract } \\
\text { realms (writing, reading, } \\
\text { counting, drawing, and } \\
\text { fabricating) as studied in } \\
\text { schools and other similar } \\
\text { sources in } \\
\text { perspective/theory }\end{array}$ & $\begin{array}{l}\text { 4. Trying, processing, and } \\
\text { presenting in concrete } \\
\text { realms (utilizing, } \\
\text { deconstructing, } \\
\text { constructing, modifying, } \\
\text { and creating) and abstract } \\
\text { realms (writing, reading, } \\
\text { counting, drawing, and } \\
\text { fabricating) as studied in } \\
\text { schools and other similar } \\
\text { sources in } \\
\text { perspective/theory }\end{array}$ & $\begin{array}{l}\text { 4. Trying, processing, and } \\
\text { presenting in concrete } \\
\text { realms (utilizing, } \\
\text { deconstructing, } \\
\text { constructing, modifying, } \\
\text { and creating) and abstract } \\
\text { realms (writing, reading, } \\
\text { counting, drawing, and } \\
\text { fabricating) as studied in } \\
\text { schools and other similar } \\
\text { sources in } \\
\text { perspective/theory }\end{array}$ \\
\hline
\end{tabular}


Courses Time Allocation for Junior High School

\begin{tabular}{|c|c|c|c|c|}
\hline \multirow{2}{*}{\multicolumn{2}{|c|}{ Subjects }} & \multicolumn{3}{|c|}{ Time allocation per Week } \\
\hline & & Grade 7 & Grade 8 & Grade9 \\
\hline \multicolumn{5}{|c|}{ Group A (General) } \\
\hline 1. & Religious and Ethical education & 3 & 3 & 3 \\
\hline 2. & Pancasila and Citizenship Education & 3 & 3 & 3 \\
\hline 3. & Indonesian Language & 6 & 6 & 6 \\
\hline 4. & Mathematics & 5 & 5 & 5 \\
\hline 5. & Science & 5 & 5 & 5 \\
\hline 6. & Social Science & 4 & 4 & 4 \\
\hline 7. & English Language & 4 & 4 & 4 \\
\hline \multicolumn{5}{|c|}{ Group B (General) } \\
\hline 1. & Art and Culture Education & 3 & 3 & 3 \\
\hline 2. & Sports Education & 3 & 3 & 3 \\
\hline 3. & Pre-Work and/or Information processing & 2 & 2 & 2 \\
\hline & Irning hours total per week & 38 & 38 & 38 \\
\hline
\end{tabular}

(The Ministry of Education and Culture Policy No. 35, 2018)

Learning competencies at Junior High Schools

\begin{tabular}{|c|c|c|c|c|c|c|}
\hline \multirow{3}{*}{ Grades } & \multicolumn{6}{|c|}{ The Total of Competencies } \\
\cline { 2 - 7 } & \multicolumn{6}{|c|}{ Subjects } \\
\cline { 2 - 7 } & Science & \multicolumn{2}{c|}{ Mathematics } & \multicolumn{2}{c|}{ Technology } \\
\cline { 2 - 7 } & Cognitive & Skills & Cognitive & Skills & Cognitive & Skills \\
\hline Grade 7 & 11 & 11 & 12 & 12 & 6 & 13 \\
\hline Grade 8 & 12 & 12 & 11 & 11 & 7 & 13 \\
\hline Grade 9 & 10 & 10 & 7 & 7 & 12 & 19 \\
\hline Total & 33 & 33 & 30 & 30 & 25 & 45 \\
\hline
\end{tabular}

(The Ministry of Education and Culture Policy No. 37, 2018) 
B. Core Competencies in senior high school

\begin{tabular}{|c|c|c|}
\hline \multicolumn{3}{|c|}{ Core Competencies } \\
\hline Grade 10 & Grade 11 & Grade 12 \\
\hline $\begin{array}{l}\text { 1. Respect and live the } \\
\text { lesson of the religion the } \\
\text { students obey to }\end{array}$ & $\begin{array}{l}\text { 1. Respect and live the } \\
\text { lesson of the religion the } \\
\text { students obey to }\end{array}$ & $\begin{array}{l}\text { 1. Respect and live the } \\
\text { lesson of the religion the } \\
\text { students obey to }\end{array}$ \\
\hline $\begin{array}{l}\text { 2. Appreciating and living } \\
\text { honest, disciplined, } \\
\text { responsible, caring } \\
\text { behavior (community } \\
\text { working, cooperation, } \\
\text { tolerant, peaceful), polite, } \\
\text { responsive and pro-active } \\
\text { and show attitudes as part } \\
\text { of solutions to various } \\
\text { problems in interacting } \\
\text { effectively with the social } \\
\text { and natural environment } \\
\text { and in placing themselves } \\
\text { as a reflection of the } \\
\text { nation in the association } \\
\text { of the world }\end{array}$ & $\begin{array}{l}\text { 2. Appreciating and living } \\
\text { honest, disciplined, } \\
\text { responsible, caring } \\
\text { behavior (community } \\
\text { working, cooperation, } \\
\text { tolerant, peaceful), polite, } \\
\text { responsive and pro-active } \\
\text { and show attitudes as part } \\
\text { of solutions to various } \\
\text { problems in interacting } \\
\text { effectively with the social } \\
\text { and natural environment } \\
\text { and in placing themselves } \\
\text { as a reflection of the } \\
\text { nation in the association } \\
\text { of the world }\end{array}$ & $\begin{array}{l}\text { 2. Appreciating and living } \\
\text { honest, disciplined, } \\
\text { responsible, caring } \\
\text { behavior (community } \\
\text { working, cooperation, } \\
\text { tolerant, peaceful), polite, } \\
\text { responsive and pro-active } \\
\text { and show attitudes as part } \\
\text { of solutions to various } \\
\text { problems in interacting } \\
\text { effectively with the social } \\
\text { and natural environment } \\
\text { and in placing themselves } \\
\text { as a reflection of the } \\
\text { nation in the association } \\
\text { of the world }\end{array}$ \\
\hline $\begin{array}{l}\text { 3. Understanding, applying, } \\
\text { analyzing factual, } \\
\text { conceptual, procedural } \\
\text { knowledge based on } \\
\text { students' curiosity about } \\
\text { science, technology, art, } \\
\text { culture, and humanities } \\
\text { with insight into } \\
\text { humanity, nationality, } \\
\text { statehood, and civilization } \\
\text { related to the causes of } \\
\text { phenomena and events, } \\
\text { and apply procedural } \\
\text { knowledge in specific } \\
\text { areas of study according } \\
\text { to students' talents and } \\
\text { interests to solve } \\
\text { problems }\end{array}$ & $\begin{array}{l}\text { 3. Understanding, applying, } \\
\text { analyzing factual, } \\
\text { conceptual, procedural, } \\
\text { metacognitive knowledge } \\
\text { based on students' } \\
\text { curiosity about science, } \\
\text { technology, art, culture, } \\
\text { and humanities with } \\
\text { insight into humanity, } \\
\text { nationality, statehood, and } \\
\text { civilization related to the } \\
\text { causes of phenomena and } \\
\text { events, and apply } \\
\text { procedural knowledge in } \\
\text { specific areas of study } \\
\text { according to students' } \\
\text { talents and interests to } \\
\text { solve problems }\end{array}$ & $\begin{array}{l}\text { 3. Understanding, applying, } \\
\text { analyzing, and evaluating } \\
\text { factual, conceptual, } \\
\text { procedural knowledge } \\
\text { based on students, } \\
\text { curiosity about science, } \\
\text { technology, art, culture, } \\
\text { and humanities with } \\
\text { insight into humanity, } \\
\text { nationality, statehood, and } \\
\text { civilization related to the } \\
\text { causes of phenomena and } \\
\text { events, and apply } \\
\text { procedural knowledge in } \\
\text { specific areas of study } \\
\text { according to students' } \\
\text { talents and interests to } \\
\text { solve problems }\end{array}$ \\
\hline $\begin{array}{l}\text { 4. Processing, reasoning, } \\
\text { and presenting in concrete } \\
\text { and abstract realms }\end{array}$ & $\begin{array}{l}\text { 4. , reasoning, and } \\
\text { presenting in concrete and } \\
\text { abstract realms related to }\end{array}$ & $\begin{array}{l}\text { 4. Processing, reasoning, } \\
\text { presenting, and creating } \\
\text { in concrete and abstract }\end{array}$ \\
\hline
\end{tabular}




\begin{tabular}{|l|l|l|}
\hline $\begin{array}{l}\text { related to the } \\
\text { development of students } \\
\text { in schools independently, } \\
\begin{array}{l}\text { and being able to use } \\
\text { methods according to } \\
\text { scientific rules }\end{array}\end{array}$ & $\begin{array}{l}\text { the development of } \\
\text { students in schools } \\
\text { independently, acting } \\
\text { effectively and being able } \\
\text { to use methods according } \\
\text { to scientific rules }\end{array}$ & $\begin{array}{l}\text { realms related to the } \\
\text { development of students } \\
\text { in schools independently, } \\
\text { acting effectively, acting } \\
\text { effectively and being able } \\
\text { to use methods according } \\
\text { to scientific rules }\end{array}$ \\
\hline
\end{tabular}

Courses Time Allocation for Senior High School

\begin{tabular}{|c|c|c|c|c|}
\hline \multirow{2}{*}{\multicolumn{2}{|c|}{ Subjects }} & \multicolumn{3}{|c|}{ Time allocation per Week } \\
\hline & & 10 & 11 & 12 \\
\hline \multicolumn{5}{|c|}{ Group A (General) } \\
\hline 1. & Religious and Ethical education & 3 & 3 & 3 \\
\hline 2. & $\begin{array}{l}\text { Pancasila and Citizenship } \\
\text { Education }\end{array}$ & 2 & 2 & 2 \\
\hline 3. & Indonesian Language & 4 & 4 & 4 \\
\hline 4. & Mathematics & 4 & 4 & 4 \\
\hline 5. & Indonesia History & 2 & 2 & 2 \\
\hline 6. & English Language & 2 & 2 & 2 \\
\hline \multicolumn{5}{|c|}{ Group B (General) } \\
\hline 7. & Art and Culture Education & 2 & 2 & 2 \\
\hline 8. & Sports Education & 3 & 3 & 3 \\
\hline 9. & Pre-Work and Entrepreneurships & 2 & 2 & 2 \\
\hline \multicolumn{2}{|c|}{ Group A and B learning hours per week } & 24 & 24 & 24 \\
\hline \multicolumn{5}{|c|}{ Group C (Interests) } \\
\hline \multicolumn{2}{|c|}{ Academic cross-interest courses } & 9 or 12 & 12 or 16 & 12 or 16 \\
\hline \multicolumn{2}{|c|}{ Elective courses } & 6 or 9 & 4 or 8 & 4 or 8 \\
\hline \multicolumn{2}{|c|}{ Group A, B, and C learning hours per week } & 42 & 44 & 44 \\
\hline
\end{tabular}

Academic Cross-Interests Courses

\begin{tabular}{|c|c|c|c|c|}
\hline \multirow{2}{*}{\multicolumn{2}{|c|}{ Subjects }} & \multicolumn{3}{|c|}{ Grades } \\
\hline & & 10 & 11 & 12 \\
\hline \multicolumn{5}{|c|}{ Science Cross-Interest Courses } \\
\hline 1. & Mathematics & 3 & 4 & 4 \\
\hline 2. & Biology & 3 & 4 & 4 \\
\hline 3. & Physics & 3 & 4 & 4 \\
\hline 4. & Chemistry & 3 & 4 & 4 \\
\hline \multicolumn{5}{|c|}{ Ii. Social Science Cross-Interest Courses } \\
\hline 1. & Geography & 3 & 4 & 4 \\
\hline
\end{tabular}




\begin{tabular}{|c|c|c|c|c|}
\hline 2. & History & 3 & 4 & 4 \\
\hline 3. & Sociology & 3 & 4 & 4 \\
\hline 4. & Economics & 3 & 4 & 4 \\
\hline \multicolumn{5}{|c|}{ III. Literature and Culture Cross-Interest Courses } \\
\hline 1. & Indonesian Literature and Language & 3 & 4 & 4 \\
\hline 2. & English Literature and Language & 3 & 4 & 4 \\
\hline 3. & $\begin{array}{l}\text { Other Literature and Language (Arab, } \\
\text { Mandarin, Japanese, Korean, Germany, } \\
\text { French) }\end{array}$ & 3 & 4 & 4 \\
\hline 4. & Anthropology & 3 & 4 & 4 \\
\hline \multicolumn{5}{|c|}{ Elective Courses*) } \\
\hline $\begin{array}{ll}\mathrm{Cr} \\
\text { anc }\end{array}$ & $\begin{array}{l}\text { s-interest and/or In-depth the cross-interest } \\
\text { or computing }\end{array}$ & 6 or 9 & 4 or 8 & 8 or 9 \\
\hline
\end{tabular}

(The Ministry of Education and Culture Policy No. 36, 2018) 
Learning Competencies at Senior High School

\begin{tabular}{|c|c|c|c|c|c|c|c|c|c|c|c|c|}
\hline \multirow[b]{3}{*}{ Grades } & \multicolumn{12}{|c|}{ The Total of Learning Competencies } \\
\hline & \multicolumn{6}{|c|}{ Science } & \multicolumn{4}{|c|}{ Mathematics } & \multirow{2}{*}{\multicolumn{2}{|c|}{ Technology }} \\
\hline & \multicolumn{2}{|c|}{ Physics } & \multicolumn{2}{|c|}{ Biology } & \multicolumn{2}{|c|}{ Chemistry } & \multicolumn{2}{|c|}{ Core Mathematics } & \multicolumn{2}{|c|}{$\begin{array}{l}\text { Specialization } \\
\text { Mathematics }\end{array}$} & & \\
\hline Grade 10 & 11 & 11 & 11 & 11 & 10 & 10 & 10 & 10 & 2 & 2 & 17 & 20 \\
\hline Grade 11 & 12 & 12 & 14 & 14 & 14 & 14 & 10 & 10 & 4 & 4 & 13 & 20 \\
\hline Grade 12 & 11 & 11 & 10 & 10 & 11 & 11 & 4 & 4 & 6 & 6 & 7 & 12 \\
\hline
\end{tabular}

(The Ministry of Education and Culture Policy No. 37, 2018) 